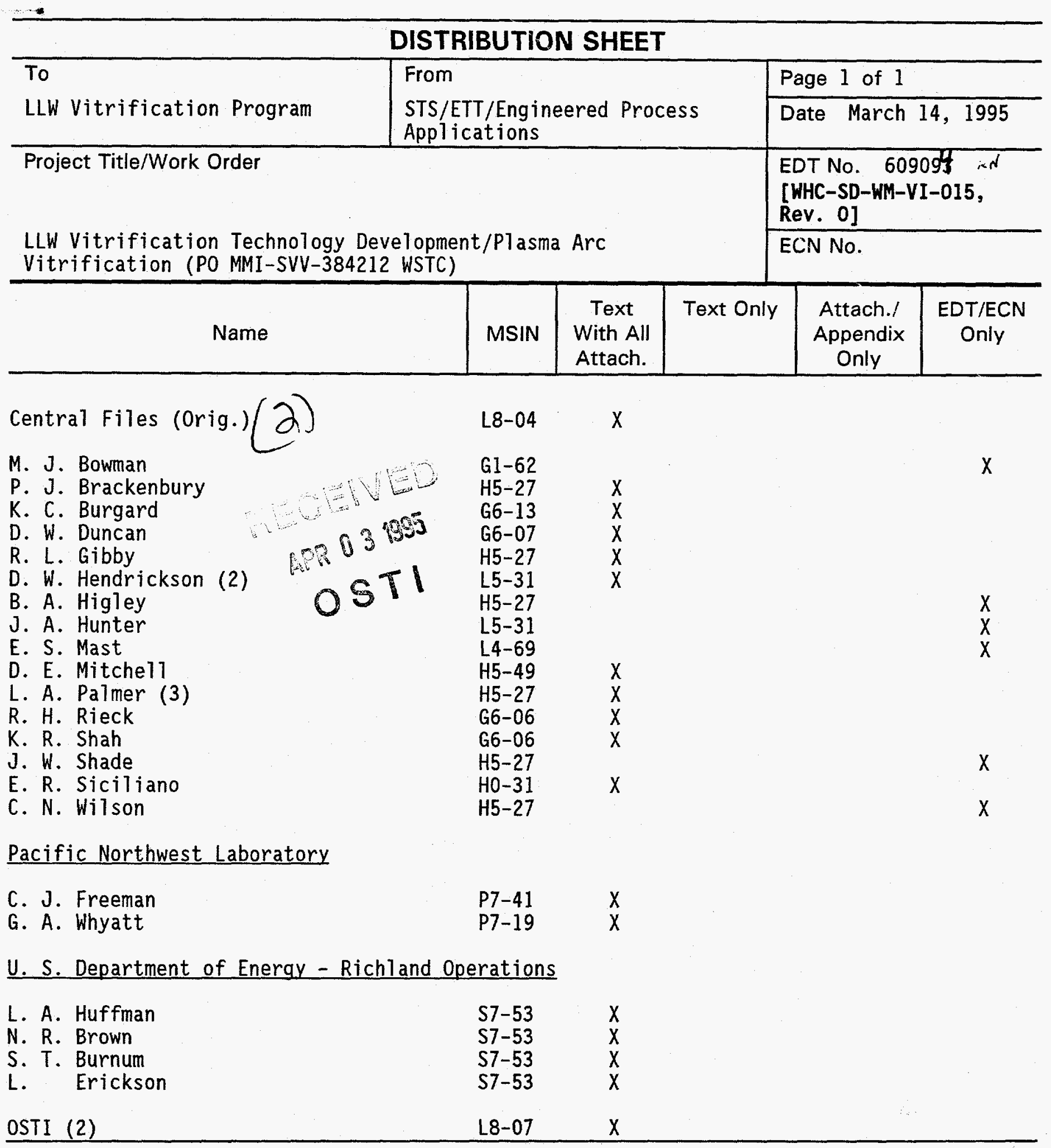




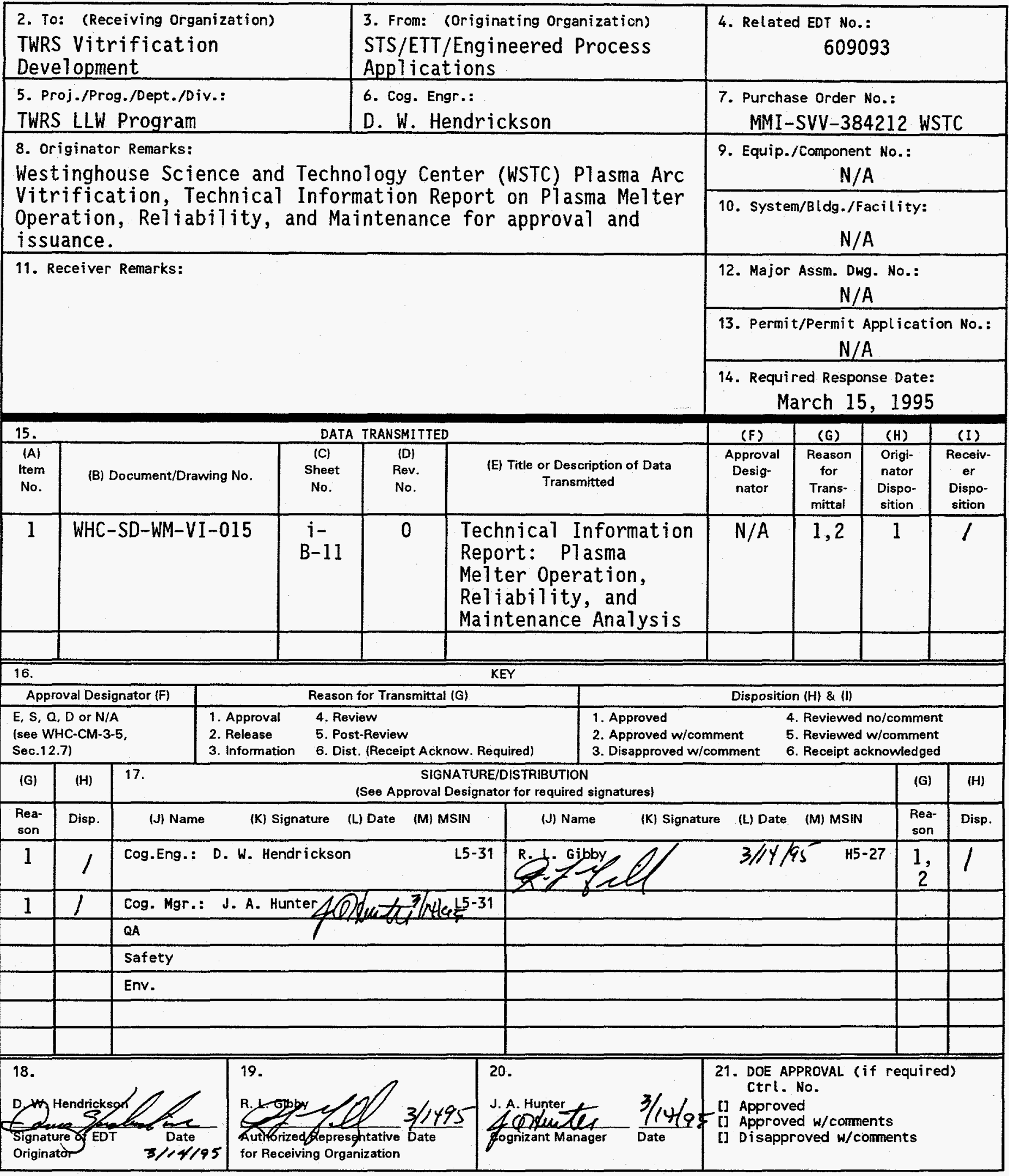

BD-7400-172-2 (04/94) GEF097 


\section{RELEASE AUTHORIZATION}

Document Number: WHC-SD-WM-VI-015, Rev. 0

Document Title: TECHNICAL INFORMATION REPORT: PLASMA MELTER

OPERATION, RELIABILITY, AND MAINTENANCE ANALYSIS

Release Date: $\quad 3 / 14 / 95$

This document was reviewed following the procedures described in WHC-CM-3-4 and is:

\section{APPROVED FOR PUBLIC RELEASE}

WHC Information Release Administration Specialist:

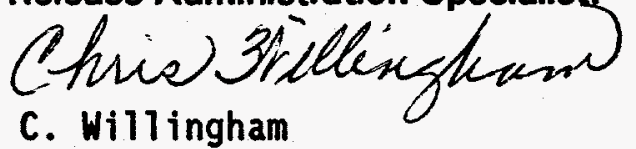

$3 / 14 / 95$

TRADEMARK DISCLAIMER. Reference herein to any specific comercial product, process, or service by trade name, trademark, manufacturer, or otherwise, does not necessarily constitute or imply its endorsement, recommendation, or favoring by the United States Government or any agency thereof or its contractors or subcontractors.

This report has been reproduced from the best available copy. Available in paper copy and aicrofiche. Printed in the United States of America. Available to the U.S. Department of Energy and its contractors from:

U.S. Department of Energy

Office of Scientific and Technical Information (OSTI)

P.0. Box 62

Oak Ridge, TI 37831

Telephone: (615) 576-8401

Available to the public from:

U.S. Department of Commerce

National Technical Information Service (NTIS)

5285 Port Royal Road

Springfield, VA 22161

Telephone: (703) $487-4650$ 


\begin{tabular}{l|l|c|}
\hline 2. Title & $\begin{array}{l}\text { 3. Number } \\
\text { WHC-SD-WM-VI-015 }\end{array}$ & 4. Rev No. \\
Technical Information Report: Plasma Melter \\
Operation, Reliability, and Maintenance Analysis
\end{tabular}

\section{Abstract}

This document provides a technical report of the operability, reliability, and maintenance of a plasma melter in the conduct of low-level waste vitrification. This report is prepared by the vendor in support of the Hanford Tank Waste Remediation System (TWRS) Low-Level Waste (LLW) Vitrification Program. The vendor providing this test report and conducting the work detailed within it [one of seven selected for glass melter testing under Purchase Order MMI-SVV-384212] is the Westinghouse Science and Technology Center (WSTC) in Pittsburgh, PA.

WSTC authors of the test plan are D. F. MCLaughlin, E. J. Lahoda, and M. F. Darr. The WSTC Program Manager for this test is D. F. McLaughlin.

This vendor technical information is a part of Phase I activities described in the above Purchase Order. This technical report is supported with plasma arc vitrification tests conducted at the site under the Purchase Order.

Provided is a process description that minimizes maintenance and downtime and includes:

- Material and energy balances;

- Equipment sizes and arrangement;

- Startup, operation maintenance and shutdown cycle descriptions; and

- Basis for scale-up to a 200 metric ton/day production facility.

Operational requirements are provided including:

- Utilities;

- Feeds;

- Labor; and

- Maintenance.

In addition, equipment reliability estimates and maintenance requirements are provided which includes a 1 ist of failure modes, responses and consequences.

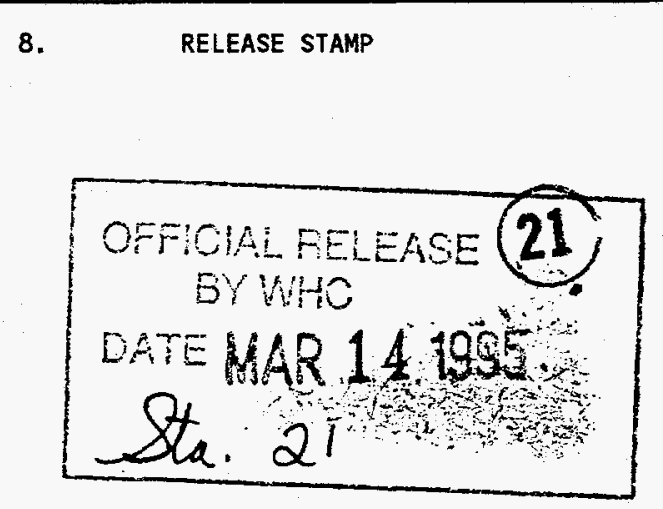


WHC-SD-WM-VI-015 Revision 0

THIS PAGE INTENTIONALLY LEFT BLANK 


\title{
TECHNICAL INFORMATION REPORT: PLASMA MELTER OPERATION, RELIABILITY AND MAINTENANCE ANALYSIS
}

\author{
D. F. McLaughlin, E. J. Lahoda, and M. F. Darr \\ Environmental Technologies
}

Contract No. DE-AC06-87RL10930

Westinghouse Hanford Company

P.O. Box 1970

Richland, WA 99532

M. Bowman, WHC Contracting Officer

WSTC General Order Reference: MMI-SVV-384212

January 31, 1995

\section{DISCLAIMER}

This report was prepared as an account of work sponsored by an agency of the United States Government. Neither the United States Government nor any agency thereof, nor any of their employees, makes any warranty, express or implied, or assumes any legal liability or responsibility for the accuracy, completeness, or usefulness of any information, apparatus, product, or process disclosed, or represents that its use would not infringe privately owned rights. Reference herein to any specific commercial product, process, or service by trade name, trademark, manufacturer, or otherwise does not necessarily constitute or imply its endorsement, recommanufacturer, or otherwise des United States Government or any agency thereof. The views and opinions of authors expressed herein do not necessarily state or reflect those of the United States Government or any agency thereof.

APPROVED:
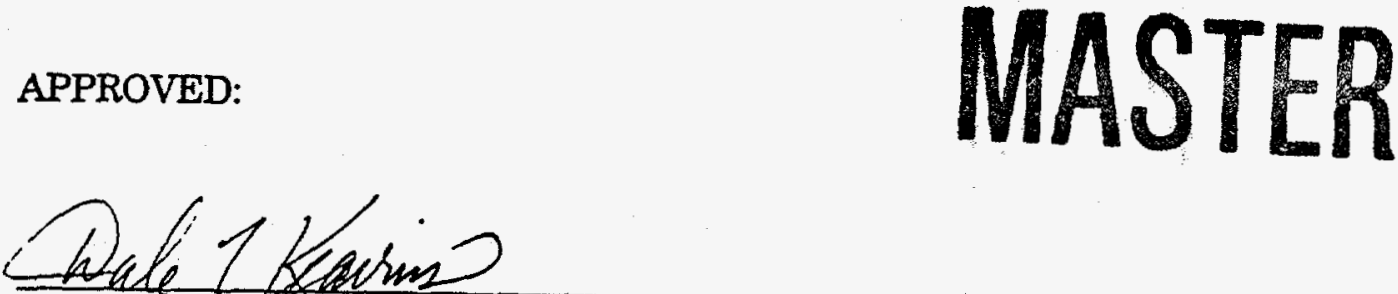

Dale L. Keairns, Manager

Environmental Technologies

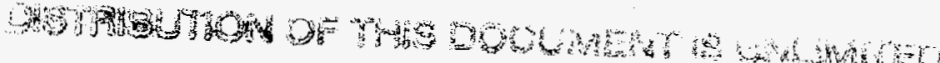


TECHNICAL INFORMATION REPORT: PLASMA MELTER OPERATION, RELIABILITY AND MAINTENANCE ANALYSIS

Prepared by:
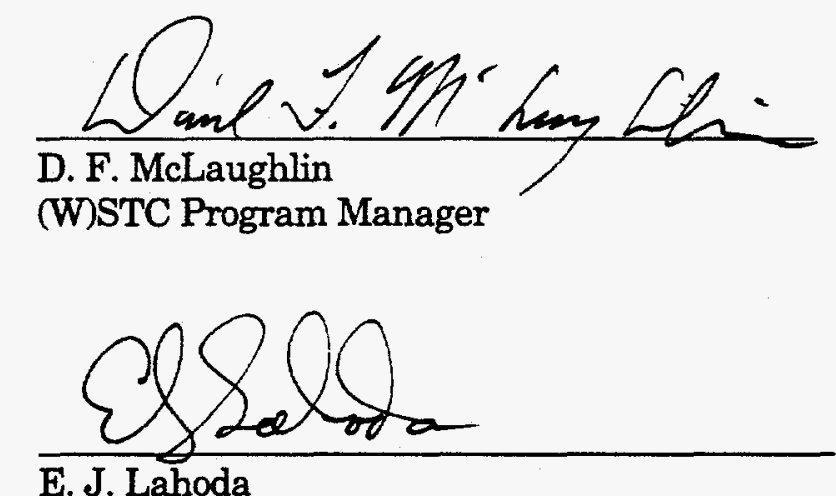

(W)STC Fellow Engineer

$$
\text { Mars Dan }
$$

M. F. Darr

(W)Plasma Center Systems Engineer

Approved By:

D. L. Keairns

(W)STC Environmental Technologies Manager

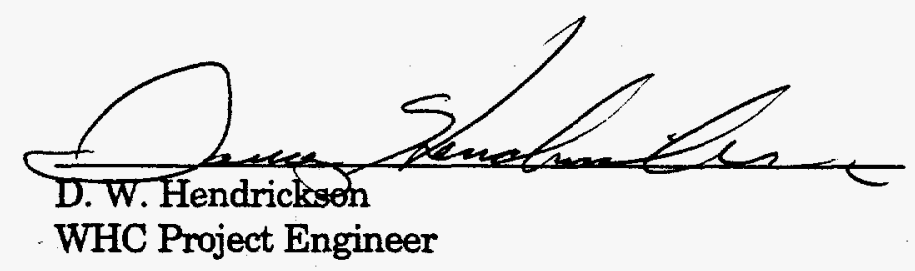




\section{CONTENTS}

LIST OF FIGURES $\ldots \ldots \ldots \ldots \ldots \ldots \ldots \ldots \ldots \ldots \ldots$ viii

LIST OF TABLES $\ldots \ldots \ldots \ldots \ldots \ldots \ldots \ldots \ldots \ldots \ldots$

LIST OF ABBREVIATIONS $\ldots \ldots \ldots \ldots \ldots \ldots \ldots \ldots \ldots$

ABSTRACT $\ldots \ldots \ldots \ldots \ldots \ldots \ldots \ldots \ldots \ldots \ldots \ldots \ldots \ldots \ldots \ldots$

1. INTRODUCTION $\ldots \ldots \ldots \ldots \ldots \ldots \ldots \ldots \ldots \ldots \ldots \ldots \ldots \ldots \ldots$

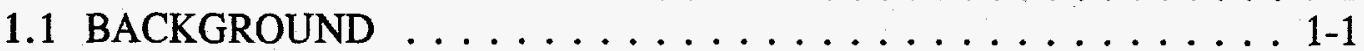

1.2 OBJECTIVE OF STUDY $\ldots \ldots \ldots \ldots \ldots \ldots \ldots \ldots$

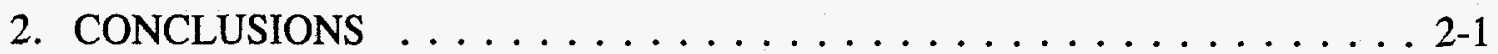

3. RECOMMENDATIONS $\ldots \ldots \ldots \ldots \ldots \ldots \ldots \ldots \ldots \ldots$. $\ldots \ldots \ldots$

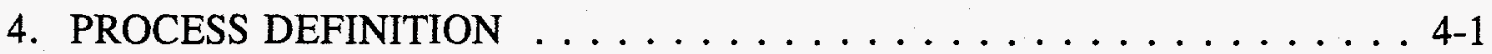

4.1 PLANT MELTER DESIGN CONCEPT . . . . . . . . . 4 4-1

4.1.1 Process Specifications . . . . . . . . . . 4-2

4.1.2 Description of Process . . . . . . . . . . . . 4-3

4.1.3 Process Layout $\ldots \ldots \ldots \ldots \ldots \ldots$. . . . . . . . .

4.2 PROCESS SCALE-UP $\ldots \ldots \ldots \ldots \ldots \ldots \ldots$. . . . . . . . . . . .

4.3 SUPPLEMENTAL GLASS RESERVOIR . . . . . . . . . . 4-15

4.4 PERIODIC MELTER OPERATION . . . . . . . . . 4 4-15

4.5 FEED SYSTEM DEFINITION $\ldots \ldots \ldots \ldots \ldots \ldots \ldots \ldots$. . . . . .

4.6 OFF-GAS TREATMENT . . . . . . . . . . . . . 4-18

5. TECHNOLOGY DEVELOPMENT STATUS . . . . . . . . . 5-1

5.1 KEY TECHNICAL ISSUES FOR PHASE II RESOLUTION . . . . 5 5-1

5.1.1 Carryover of Alkali Metals into the Offgas System .... . 5-2

5.1 .2 Feed Pump Wear . . . . . . . . . . . . . . 5-4

5.1 .3 Refractory Wear . . . . . . . . . . . . . 5-4

$5.1 .4 \mathrm{NO}_{\mathrm{x}}$ Reduction . . . . . . . . . . . . . 5-5

5.1.5 Tuyere Design and Orientation ........... 5-5

5.1.6 Avoidance of Solids Buildup in Offgas Ducts ...... . 5-6

5.1.7 Design of a Pour Spout with Minimal Maintenance

Requirements . . . . . . . . . . . . . 5-7

5.2 POTENTIAL WASTE COMPOSITIONS $\ldots \ldots \ldots \ldots \ldots \ldots$ 5-7

5.3 APPLICATION OF THE PLASMA MELTER AT HANFORD

AS COMPARED TO PREVIOUS WESTINGHOUSE

EXPERIENCE . . . . . . . . . . . . . 5-10 


\section{CONTENTS - continued.}

6. OPERATING PERFORMANCE CHARACTERISTICS $\ldots \ldots \ldots \ldots$. . .

6.1 OFF-GAS VOLUME AND CHARACTERISTICS $\ldots \ldots \ldots \ldots 6-1$

6.2 WASTE TREATMENT AND RECYCLE . . . . . . . 6-5

6.3 ACCEPTABLE MELT PROPERTIES . . . . . . . . . . . 6-6

6.4 MELTER SYSTEM UTILITIES AND SERVICES $\ldots \ldots \ldots \ldots .6-7$

6.4 .1 Utilities . . . . . . . . . . . . . . 6-7

6.4 .2 Feeds $\ldots \ldots \ldots \ldots \ldots \ldots \ldots \ldots \ldots$. . . . . . . . .

6.4 .3 Labor . . . . . . . . . . . . . . . . . . 6-10

6.4.4 Maintenance Labor and Parts Costs . . . . . . . . . 6-11

7. OPERATING AND MAINTENANCE CONCEPTS DEFINITION $\ldots \ldots \ldots$ 7-1

7.1 MELTER CELL MECHANICAL OPERATIONS AND

MAINTENANCE . . . . . . . . . . . . . 7-2

7.1.1 Expected Equipment Maintenance and Reliability . . . . . . 7-3

7.1.2 Decontamination Operations . . . . . . . . . . . . . 7-4

7.1.3 Maintenance Labor and Parts Costs . . . . . . . . . 7-5

7.2 PROCESS CONTROL AND INSTRUMENTATION . . . . . 7-5

7.2.1 Required Instrumentation . . . . . . . . . . . 7-5

7.3 VIEWING SYSTEMS $\ldots \ldots \ldots \ldots \ldots \ldots \ldots \ldots$. $7-6$

7.4 MELTER STARTUP, OPERATION, RESTART, AND

SHUTDOWN CYCLES $\ldots \ldots \ldots \ldots \ldots \ldots \ldots \ldots . \ldots . \ldots .7$

7.4.1 Cold Startup and Operation . . . . . . . . . . . . 7-8

7.4.2 Torch Maintenance . . . . . . . . . . . . . . . . . . 7-8

7.4.3 Changeout of Waste Container During Glass Pouring . . . . 7-9

7.4.4 Idle and Hot Restart . . . . . . . . . . . . . . 7-9

7.4.5 Emergency Shutdown Followed by a Warm Restart . . . 7-11

7.4.6 Shutdown Cycle . . . . . . . . . . . . . . 7-11

8. MELTER RELIABILITY ASSESSMENT AND FAILURE ANALYSIS . . 8 8-1

8.1 ELECTRODE WEAR $\ldots \ldots \ldots \ldots \ldots \ldots \ldots \ldots . \ldots \ldots$

8.2 FEEDLINE PLUG $\ldots \ldots \ldots \ldots \ldots \ldots \ldots \ldots . \ldots \ldots$. $\ldots \ldots \ldots$

8.3 FEED OR OFFGAS EVAPORATOR OUTAGES $\ldots \ldots \ldots \ldots$. . 8-2

8.3.1 Pump Outage . . . . . . . . . . . . . 8-2

8.3.2 Line Plug . . . . . . . . . . . . . . 8-2

8.3.3 Heat Exchanger Fouling . . . . . . . . . . 8 8-2

8.4 SITE POWER OUTAGE $\ldots \ldots \ldots \ldots \ldots \ldots . \ldots .2$

8.5 GLASSFORMER FEED LINE PLUG $\ldots \ldots \ldots \ldots \ldots \ldots$

8.6 FRIT PUMP OUTAGE $\ldots \ldots \ldots \ldots \ldots \ldots . \ldots \ldots$. . . . . . . . .

8.7 COOLING WATER OUTAGES $\ldots \ldots \ldots \ldots \ldots \ldots$ 8-3

8.7 .1 Chiller Outage . . . . . . . . . . . . 8-3

8.7.2 Circulating Pump Outage $\ldots \ldots \ldots \ldots \ldots$ 8-3

8.8 CONTROL SYSTEM MALFUNCTION $\ldots \ldots \ldots \ldots \ldots \ldots$ 8-3

8.9 OFFGAS SYSTEM OUTAGE $\ldots \ldots \ldots \ldots \ldots \ldots \ldots . . .8 .4$

8.10 POWER SUPPLY OUTAGE $\ldots \ldots \ldots \ldots \ldots \ldots \ldots . \ldots .4$

8.11 TAP HOLE BLOCKAGE $\ldots \ldots \ldots \ldots \ldots \ldots \ldots \ldots .4$.

8.12 GLOW BAR FAILURE $\ldots \ldots \ldots \ldots \ldots \ldots \ldots . \ldots \ldots$ 


\section{CONTENTS - continued.}

8.13 BUILDUP OF MATERIAL IN TUYERE . . . . . . . . . 8-4

8.14 WATER COOLED WALL RUPTURE INTO MELTER . . . . . 8-4

8.14.1 Small Rupture $(<2$ liters/minute $) \ldots \ldots \ldots \ldots \ldots$. 8 . . .

8.14.2 Large Rupture ( $>2$ liters/minute) . . . . . . . . 8 8-5

8.15 WATER COOLED WALL RUPTURE OUT OF MELTER . . . . 8 8-5

APPENDIX A. LETTER 9550084/384212-001 M. J. BOWMAN TO D.F.

MCLAUGHLIN JANUARY $6,1995 \ldots \ldots \ldots \ldots \ldots \ldots$. . . . .

APPENDIX B. PNL GLASS COMPOSITION $\ldots \ldots \ldots \ldots \ldots \ldots$. . . $\ldots \ldots$ 


\section{LIST OF FIGURES}

Figure 1.1 - Westinghouse Plasma Melter for the Vitrification of Simulated

Low-Level Waste

Figure 1.2 - Diagram of the Crucible Portion of the 14 ton per day Plasma Melter .... 1-4

Figure 1.3 - Cross-section of the Westinghouse Marc 11 Plasma Torch.........................1-5

Figure 1.4 - Plasma Torch Systems Instrumentation Diagram.................................... 1-7

Figure 1.5 - Schematic of Plasma Melter System Instrumentation ............................ 1-9

Figure 1.6 - Sampling and Process Measurement Locations in Offgas System ......... 1-10

Figure 4.1 - Block Diagram of Westinghouse Low Level Waste Vitrification Facility .4-5

Figure 4.2 - Diagram of Tuyere and Crucible Areas of the Westinghouse Vitrification

Reactor.

Figure 4.3 - Arrangement of Feed and Purge Line Header

4-12

Figure 4.4 - Proposed Layout of Westinghouse Low Level Waste Vitrification

Facility 4-13

Figure 4.5 - Waste and Frit Feed Systems Flowsheet

Figure 4.6 - Off-Gas System Flowsheet.

Figure 5.1 - Proposed Pour Spout Design .................................................................. 5-9

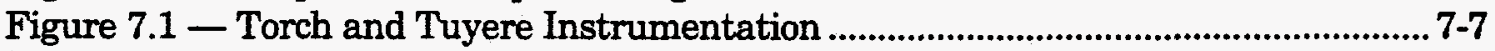

Figure 7.2 - Detail of Torch Mounting Showing Isolation Valve.................................. 7-10 


\section{LIST OF TABLES}

Table 4.1. Vitrification Performance and Process Specifications

Table 4.2 - Process Specifications for 26-Hour Demonstration Test.

Table 4.3(a) - Mass and Energy Balance for the Westinghouse Plasma Melter Process

(Non-Borosilicate Frit Glassformer)

Table 4.3(b) - Mass and Energy Balance for the Westinghouse Plasma Melter Process

(Borosilicate Frit Glassformer)

Table 4.3(c) - Mass and Energy Balance for the Westinghouse Plasma Melter Process

(Non-Borosilicate Batch Glassformer)

Table 5.1 - Preliminary Candidate Phase II Non-Borosilicate Glass Compositions

Table 5.2 - Components with $>10 \%$ Change Between the Double-Shell Slurry Feed and

the Remaining Inventory

Table 5.3 - Plasma Vitrification and Melting Applications .......................................5-11

Table 6.1 - Characteristic Offgas from Phase I Plasma Melter Operation .......................6-2

Table 6.2 - Thermodynamic Predictions of Hanford Tank Waste Species Volatilities at $1250^{\circ} \mathrm{C}$

Table 6.3 - Soda Retention and Leachability for Phase I Test Operations.......................6-6

Table 6.4 - Melt Property Specifications ......................................................................6-6

Table 6.5 - Utility Requirements for 200 Tonne/day Plasma Vitrification Facility ........6-8

Table 6.6 - Cooling Water and Process Air Specifications for Plasma Torch System .....6-8

Table 7.1 - Crucible Instrumentation. 


\section{LIST OF ABBREVIATIONS}

$\begin{array}{ll}\text { ALARA } & \text { As Low As Reasonably Achievable (radiation protection philosophy) } \\ \text { DOE } & \text { United States Department of Energy } \\ \text { DSSF } & \text { Double Shell Slurry Feed (Hanford waste tank composition) } \\ \text { DWPF } & \text { Savannah River Defense Waste Processing Facility } \\ \text { EA } & \text { Environmental Assessment Glass Composition } \\ \text { HEPA } & \text { High-Efficiency Particle Attenuation (filter) } \\ \text { HLW } & \text { High-Level Radioactive Waste } \\ \text { kWe } & \text { Kilowatts electric } \\ \text { LLW } & \text { Low-Level Radioactive Waste } \\ \text { MSW } & \text { Municipal Solid Waste } \\ \text { MWe } & \text { Megawatts electric } \\ \text { PCT } & \text { Product Consistency Test (glass leachability metric) } \\ \text { PLC } & \text { Programmable Logic Controller } \\ \text { PNL } & \text { Battelle Pacific Northwest Laboratories } \\ \text { RFP } & \text { Request for Proposal } \\ \text { SOW } & \text { Statement of Work } \\ \text { SRTC } & \text { Savannah River Technology Center } \\ \text { STC } & \text { Westinghouse) Science and Technology Center } \\ \text { TSC } & \text { Technical Selection Criteria } \\ \text { TSS } & \text { Total Suspended Solids } \\ \text { WSTC } & \text { Westinghouse Science and Technology Center } \\ \text { WHC } & \text { Westinghouse Hanford Company } \\ \text { XRF } & \text { X-ray Diffraction Analysis }\end{array}$




\section{ABSTRACT}

The Technical Information Report provides the technical information necessary for Hanford personnel to evaluate the applicability, reliability and maintainability of the Plasma Vitrification process successfully tested by the Westinghouse Science and Technology Center. Provided is a process description that minimizes maintenance and downtime and includes:

- Material and energy balances;

- Equipment sizes and arrangement;

- Startup, operation, maintenance and shutdown cycle descriptions; and

- Basis for scale-up to a 200 metric ton/day production facility.

In addition, equipment reliability estimates and maintenance requirements are provided which includes a list of failure modes, responses and consequences. Finally, operational requirements are provided including:

- Utilities;

- Feeds;

- Labor,

- Maintenance. 
WHC-SD-WM-VI-015 Revision 0

THIS PAGE INTENTIONALLY LEFT BLANK 


\section{INTRODUCTION}

\subsection{BACKGROUND}

Westinghouse Hanford Company (WHC) has contracted to the Westinghouse Science and Technology Center (WSTC) to conduct demonstration testing of Plasma Melting technology for conversion of simulated high-sodium, low-level radioactive liquid waste (LLW) into good-quality glass for the purpose of long term immobilization and storage by the Department of Energy (DOE). A process is sought which is energy efficient, readily scaleable to 100-200 tonnes/day glass production rate, exhibits good capture efficiency for sodium and other volatile waste species, is reliable and easily. maintainable, and which produces a glass product which exhibits low leachability and good homogeneity. In satisfaction of the contract, three preliminary Trial Heats and one long term Demonstration Test have been carried out at the Westinghouse Plasma Center at the Waltz Mill site in Madison, Pennsylvania. These tests make up the Phase 1 tests required for this contract. The current document provides a detailed description of the technical background required for evaluating this process. These data are based on the results of the 1994 tests and previous Westinghouse experience.

The Westinghouse Plasma Melter is the basis for the vitrification process proposed by Westinghouse STC for Hanford's low-level waste. The Plasma Melter, although non-conventional for low-level radioactive waste vitrification, has been tested successfully on two occasions by Westinghouse for calcination of simulated high-level waste containing in excess of $15 \mathrm{M}$ sodium salts. In the 1993 test, 3.5 tonnes of Hanford simulated high level waste slurry were fed to the Plasma Melter, producing $1300 \mathrm{~kg}$ of molten calcine at temperatures of 650 to $1000^{\circ} \mathrm{C}$. These results were the basis for the test program performed in 1994 on the Hanford low level wastes.

The heart of the vitrification process is the Plasma Fired Vitrification Reactor, shown in Figure 1.1. The overall process is simple and straightforward, and involves no pretreatment of input waste feed other than possible evaporative concentration to increase overall operating efficiency. The configuration shown is that of the existing pilot-scale 9 tonnes/day plasma melting facility at the WSTC Waltz Mill Plasma Center, where both the calcination and Phase I vitrification test programs were carried out. The Plasma Melter is a vertical shaft design with a height of 6.7 meters and an outer shell diameter of 1.2 meters, refractory lined to provide a 0.76 meter inner diameter. The shaft is lined with a high-alumina (91\%) refractory material which has shown good resistance to vitreous slag materials in past melter testing. A refractory lined crucible 
(Figure 1.2) mounts to the bottom of the vertical shaft with a bolted flange for easy assembly and disassembly. The crucible refractory lining is an alumina-chromia (ruby) ceramic material capable of containing alkaline reactants at temperatures of approximately $1400^{\circ} \mathrm{C}$ with little or no degradation. A very similar refractory composition is used in the Savannah River Defense Waste Processing Facility (DWPF) high-level waste vitrification facility. A tap hole at the bottom of the crucible is integrated with a heated spout assembly to provide a flow path for molten, vitrified waste glass. The vitrified product is collected in carbon steel mold boxes ( $107 \mathrm{~cm} \mathrm{x} 103$ $\mathrm{cm} \times 61 \mathrm{~cm}$ deep) supported by sand-lined steel mold boxes and mounted on rails for easy removal from the Plasma Melter.

Process heat is supplied by a Westinghouse non-transferred arc plasma torch, mounted to one side of the crucible zone in an entry duct known as the tuyere. A commercially available, production scale Westinghouse Marc-11 Plasma Torch (see Figure 1.3) supplies the thermal energy to the Plasma Melter. The torch is rated at 2300 kilowatts electric ( $\mathrm{kWe}$ ) input power with an electrical-to-thermal efficiency of between 80 and $90 \%$. The torch design utilizes a pair of cylindrical, water cooled electrodes to generate a dc arc, which is rotated by an electric field. Process gas is injected through the cylindrical electrode gap at typical flowrates of 3 to 4 standard cubic meters per minute (100-150 scfm). The high velocity of the gas carries the arc into the throat of the torch, and heats the working gas to extremely high temperatures. Field coils rotate the electrically conductive plasma at high rotational velocities, such that the point of contact of the arc with the downstream electrode is constantly moving. This feature prevents ablation of the electrode, and leads to electrode lifetimes in excess of 1,500 hours before replacement. The superheated process gas is mixed with 7 to 10 standard cubic meters per minute (250-350 scfm) of shroud gas at the torch nozzle, which serves to reduce the plume temperature and protect the tuyere refractory from thermal damage. In addition $0.7 \mathrm{std}-\mathrm{m}^{3} / \mathrm{min}$ of $\mathrm{N}_{2} / \mathrm{O}_{2} / \mathrm{CO}_{2}$ and $3.5 \mathrm{std}-\mathrm{m}^{3} / \mathrm{min}$ of steam are generated from calcination of the waste at the nominal $3.8 \mathrm{liters} / \mathrm{min}(1.0 \mathrm{gpm})$ simulant processing rate evaluated during Phase I testing, for a total of approximately 3.5 to $4.5 \mathrm{std}-\mathrm{m}^{3}$ of offgas per liter of simulant.

The Westinghouse non-transferred arc plasma torch is a rugged and commercially available technology, and is heavily instrumented with temperature, pressure, and flow sensors to accurately characterize its performance (see Figure 1.4).. A unique attribute of the non-transferred arc torch is its ability to decouple and independently control the gas temperature and chemistry. The torch is capable of operating on air (the most common choice due to economic considerations), nitrogen (if oxidizing conditions are to be avoided), hydrogen (providing a reducing chemistry), or inert gases such as helium or argon (suppressing all arc chemistry). Chemically active gases such as oxygen or even chlorine may also be used, although more reactive gases shorten the average electrode lifetime. Minimization of the quantity of non-condensable 


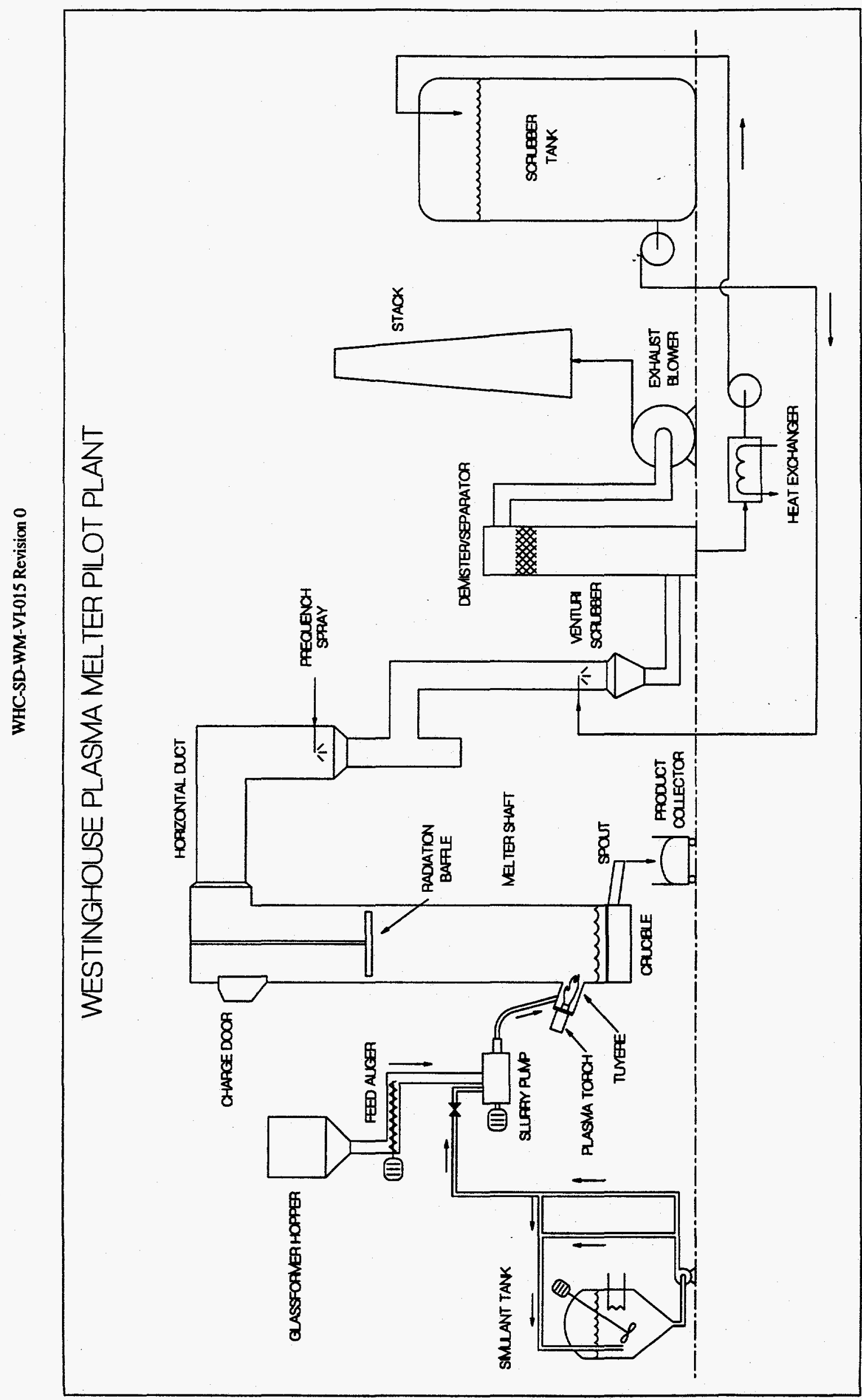

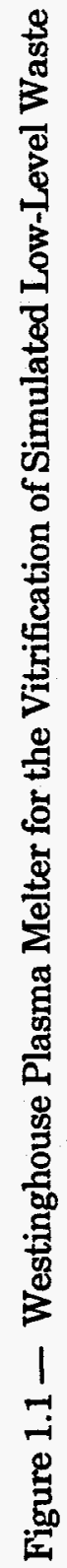




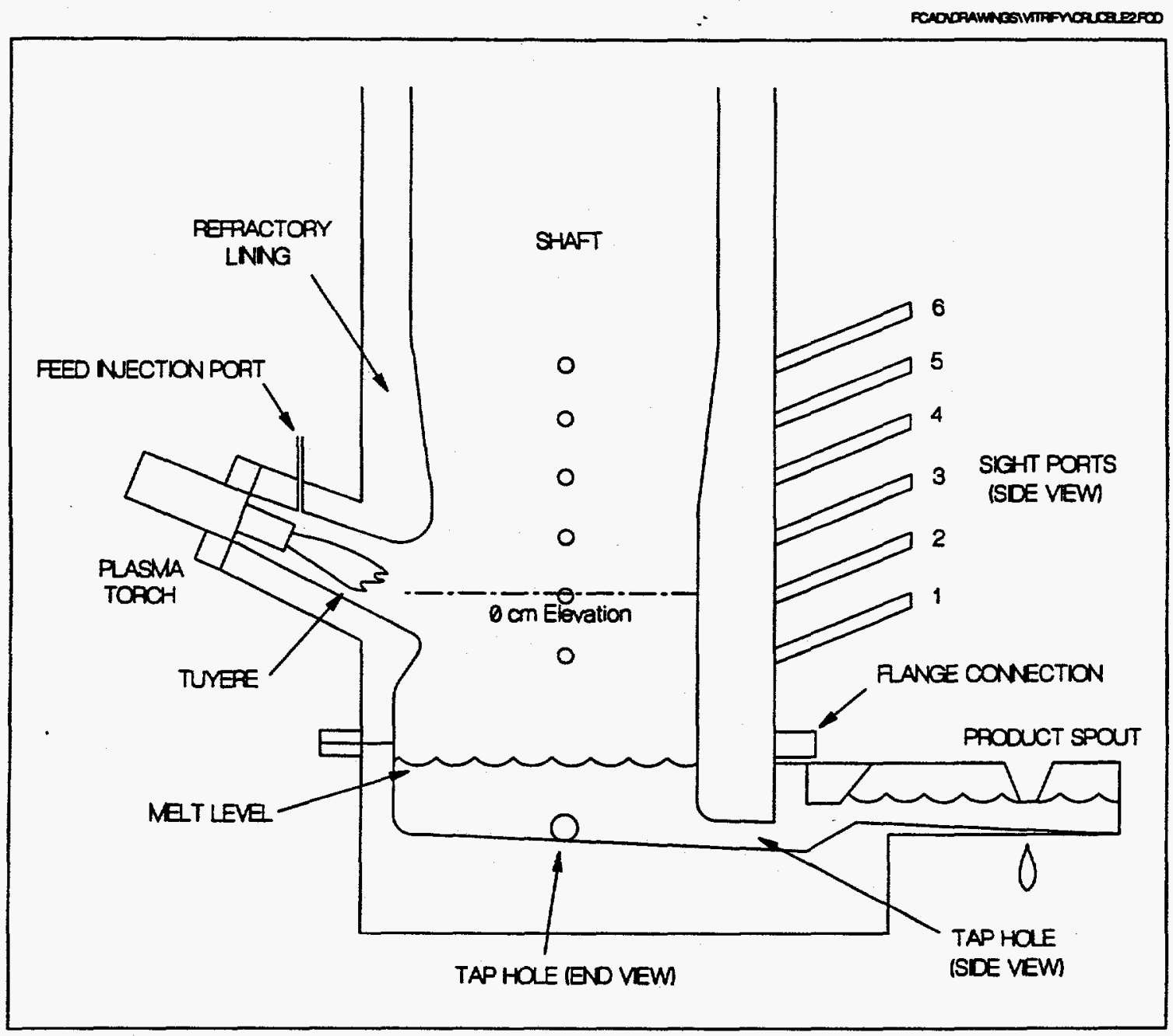

Figure 1.2 - Diagram of the Crucible Portion of the 14 ton per day Plasma Melter 


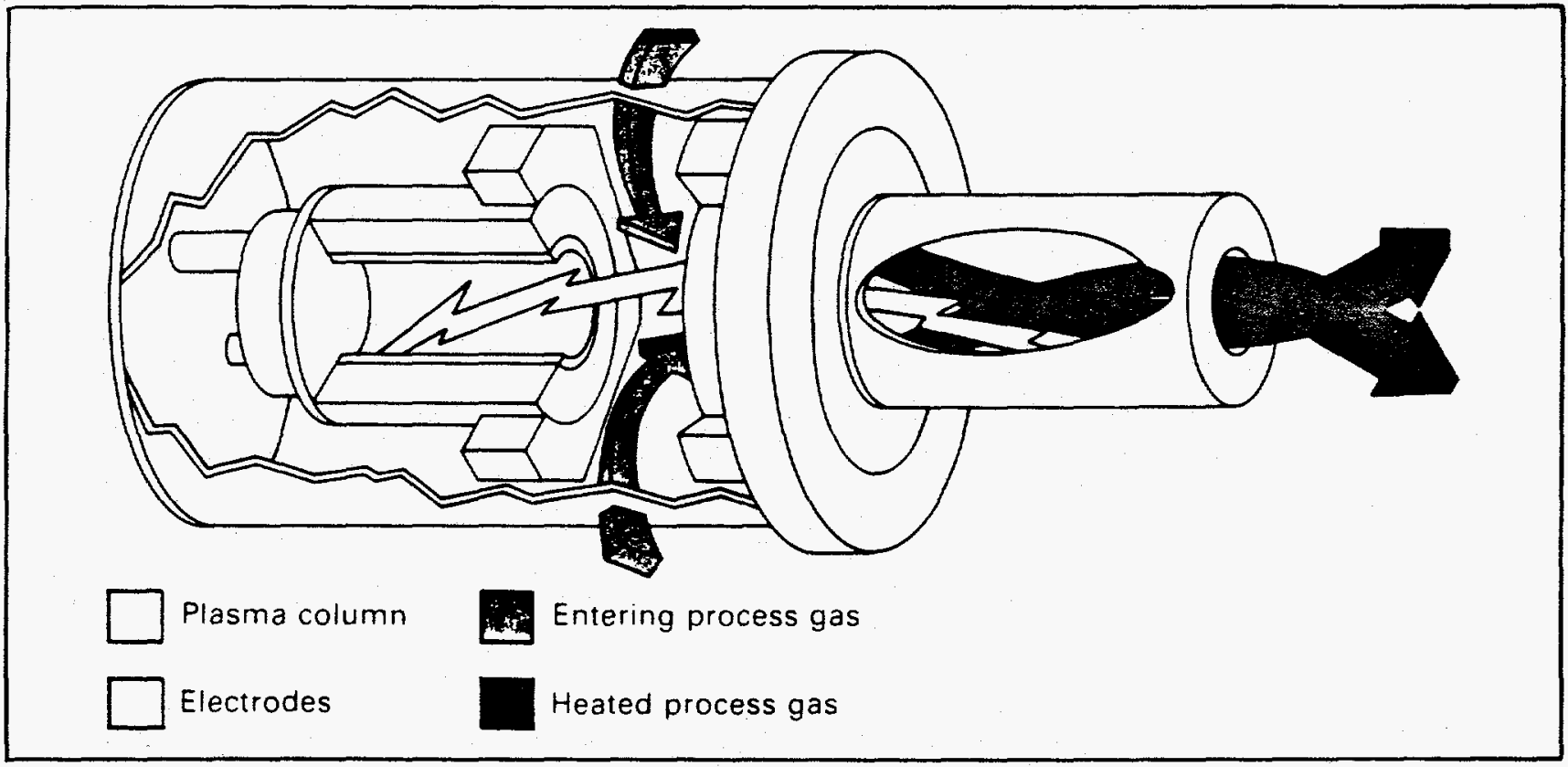

Figure 1.3 - Cross-section of the Westinghouse Marc 11 Plasma Torch 
offgas generated by the plasma vitrification system might be accomplished by the use of steam as the shroud gas.

Because of the simplicity of its construction, maintenance on the Westinghouse plasma torch is simple and requires little time. In typical industrial operations, the plasma torch is connected to the melter by simple flange connections, with all of the required utilities connected through the mounting flange. Disconnection of four bolts, two electrical connectors, and several quick-connect fittings supplying air and cooling water allows the torch to be changed out in non-radioactive environments in less than fifteen minutes. Replacement of the electrodes is also a quick operation, requiring less than an hour total labor time. Glovebox operation would be somewhat more involved, and design changes in the torch are possible to further simplify maintenance in a radioactively contaminated environment.

The overall process is readily scaleable due to its simplicity and inherent modularity. In a typical plant configuration, a vitrification reactor would consist of a number of vitrification tuyeres (6 to 10) surrounding a single central crucible and product collection system. This Westinghouse design has been operated commercially (for example at the General Motors Corporation plant in Defiance, Ohio) at a throughput of 90 tonnes/day metal melting capacity in a single melter operating with eight torch/tuyere assemblies, with an overall melter diameter of four meters. For waste vitrification, the waste and glassformer slurry would be injected directly into the tuyere through a simple straight-pipe injection nozzle at sufficient velocity to cause rapid mixing of the waste with the extremely hot $\left(5000^{\circ} \mathrm{C}\right)$ plume generated by the plasma torch. The water content of the waste is flashed to steam, with a mixing temperature well in excess of $2000^{\circ} \mathrm{C}$. Decomposition of the nitrates and nitrites in the waste mixture to oxides occurs in the tuyere, as well as destruction of organic carbon. Glassformers are added either as batch chemicals or in the form of premelted frit through a metered solids feed auger. This material is preblended with waste simulant and injected by a progressing cavity pump into the tuyere.

The melting facility is well instrumented with temperature, pressure, and flow means for characterizing performance, as well as comprehensive on-line process gas analysis (see Figure 1.5). The primary process control parameter to control torch power is the melt temperature, which is monitored by thermocouples in the melt zone (T17) and at the pour spout (T18). Additional thermal data is derived from thermocouples imbedded in the refractory of the crucible, close to the inner surface in both the crucible and tap hole. Use of multiple temperature measurements to ascertain the bulk melt temperature allows any spatial gradients to be averaged in establishing a single nominal glass temperature. As the melt temperature decreases and the molten product viscosity increases, the arc current to the torch may be increased at the discretion of the torch operator, increasing the output power of the torch and consequently the melt temperature. The feed rate of the glassformer powder is held constant by the feed auger. The feed rate of waste simulant may be held constant by a control loop through the feed control valve. The product glass is continuously poured through the spout into 


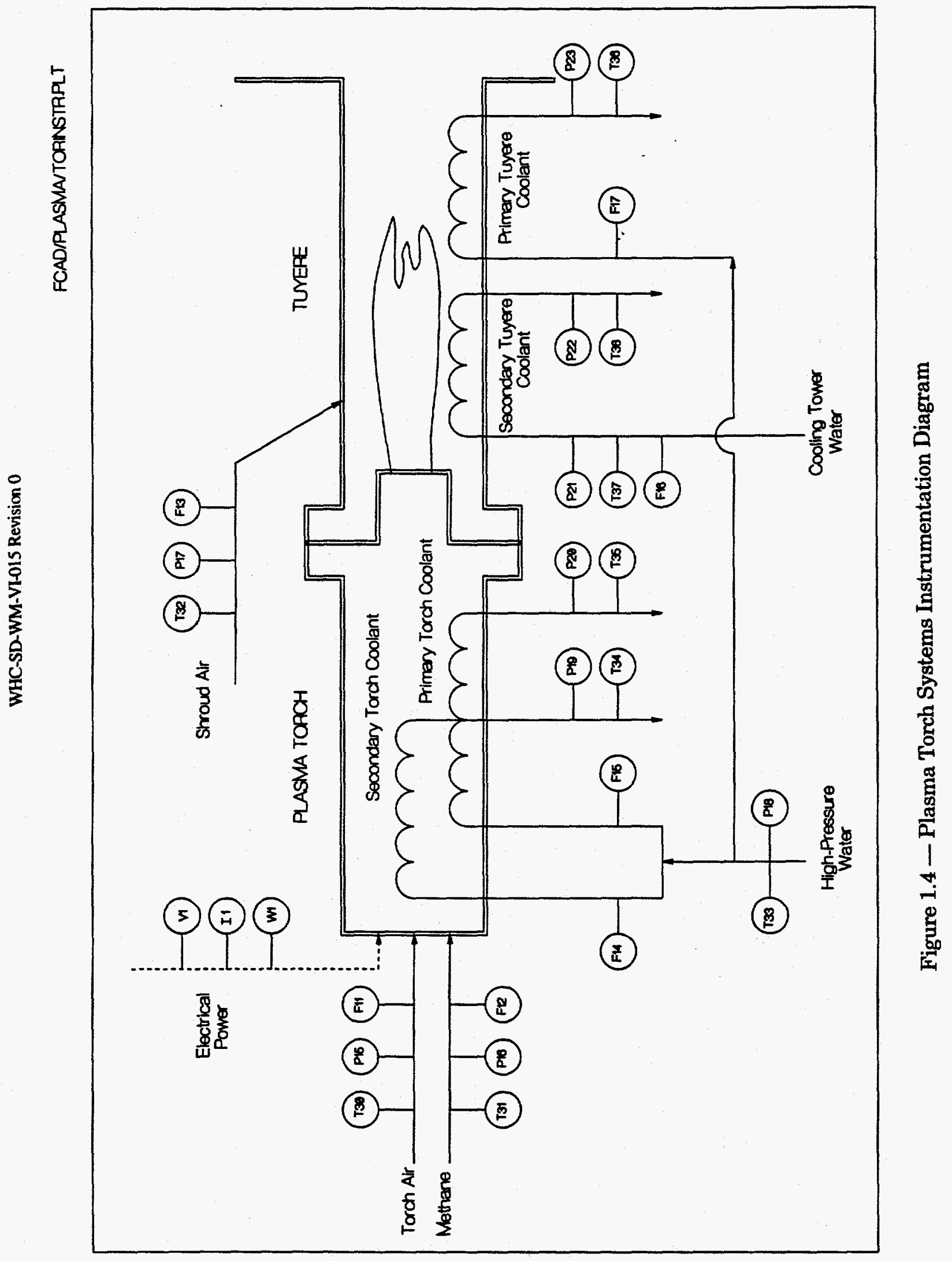


carbon steel mold boxes (in the case of the Phase I demonstrations) or other product collection system to be designed for actual radioactive operation.

The off-gas handling system (see Figure 4.6) proposed for actual plant operation is comprised of components well established for handling of radioactive offgases, and consists of a quenching system, a high-efficiency scrubber, a separator/demister, a heat exchanger, roughing filters, high-fficiency particle attenuation (HEPA) filters, regenerative blowers, a final sand filtration system, and a scrubber reservoir tank. (Offgas handling in the Phase I demonstration system used a single-stage venturi scrubber in place of the packed bed scrubber to remove heavy particulates from the exhaust stream, and eliminated the downstream filtration system - see Figure 1.6). The separator/demister removes additional solid particulates and aerosols and thoroughly scrubs the exhaust stream, capturing water soluble off-gas products and sending them to the scrubber tank. Environmentally acceptable $\mathrm{N}_{2} / \mathrm{O}_{2} / \mathrm{CO}_{2}$ off-gas is ejected by the blower through an exhaust stack. The heat exchanger in the scrubber tank removes thermal energy absorbed from the off-gas stream by the scrubber system and prevents excessive temperature rise in the scrubber reservoir tank.

A secondary scrubber liquor processing system provides for recycle of volatiles and entrained material. The heat exchanger in the scrubber tank removes thermal energy absorbed from the offgas stream by the scrubber system, and prevents excessive temperatures in the scrubber reservoir tank. To prevent continual accumulation of both water and volatile species in the scrubber water, a bleed stream in continuously removed and processed by an evaporator to remove water collected from the waste steam condensation. This concentrated bleed stream is then reinjected into the melter feed, returning the volatile salts to the vitrification process. For all species which have a reasonable solubility in the glass product, steady state operation will result in which the feed entering the tuyere will be enriched in these species. Alternatively, this stream could be redirected to another waste handling system specifically designed to deal with volatiles having low glass solubility (for example halides).

The scrubber tank recirculating system used during Phase I demonstration has two sampling ports (S8 and S9) for removing grab samples for analysis. Continuous online sampling of shaft gases was done for $\mathrm{CO}_{2}, \mathrm{CO}, \mathrm{H}_{2}$, and $\mathrm{NO}_{\mathrm{x}}$. The gases were extracted from the shaft by a small pump, processed by a sample conditioner to cool and dry the gases, and then passed through four analyzers. Monitoring points are indicated in Figure 1.6. The flow rates and temperatures of the gases and scrubber liquids were monitored and recorded via datalogger. Pressures in the gas train were also monitored and manually recorded. The gas sampling points are also indicated on Figure 1.6. These ports were used to take samples for the on-line non-condensable gas composition equipment. 


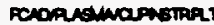

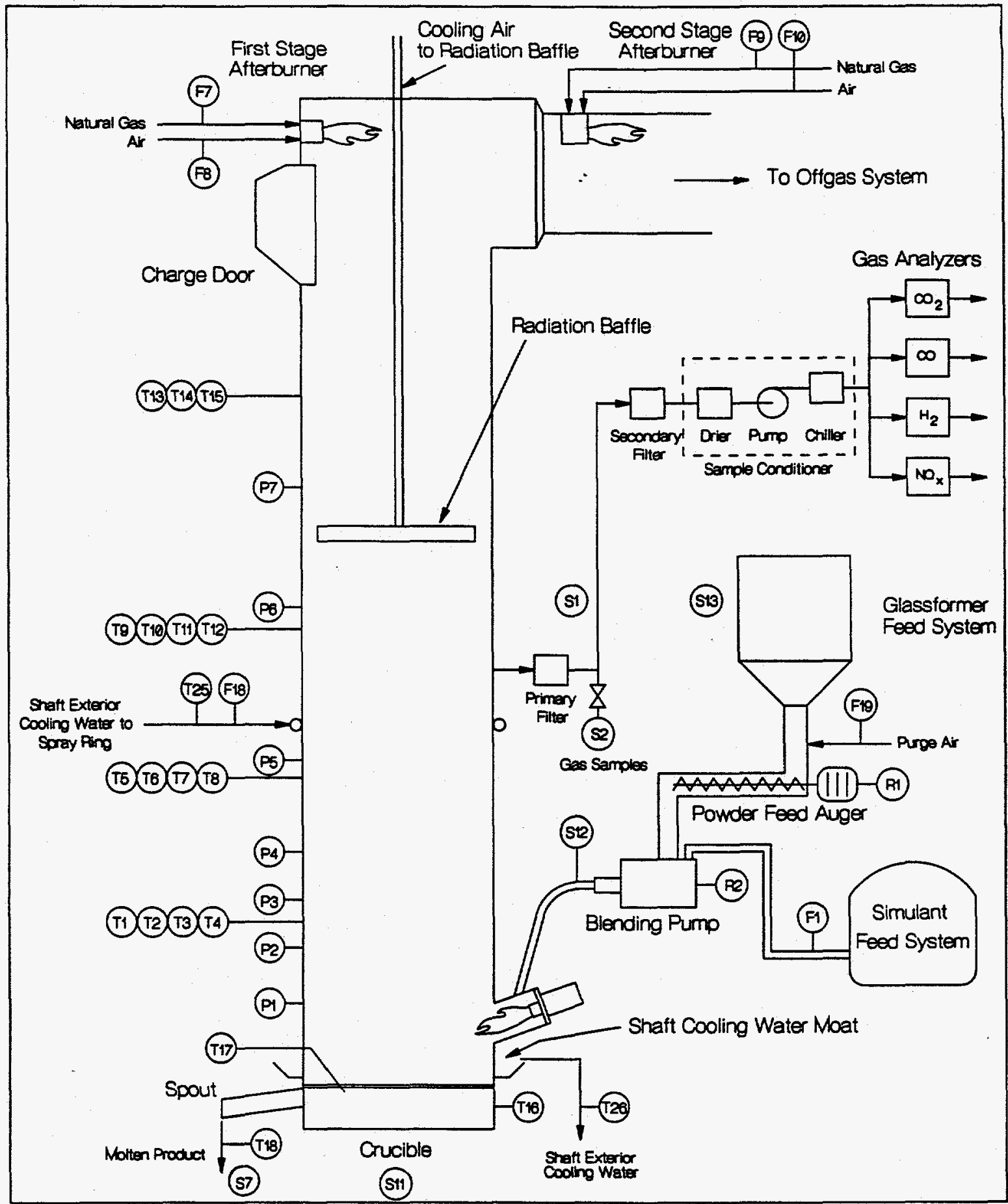

Figure 1.5 - Schematic of Plasma Melter System Instrumentation 


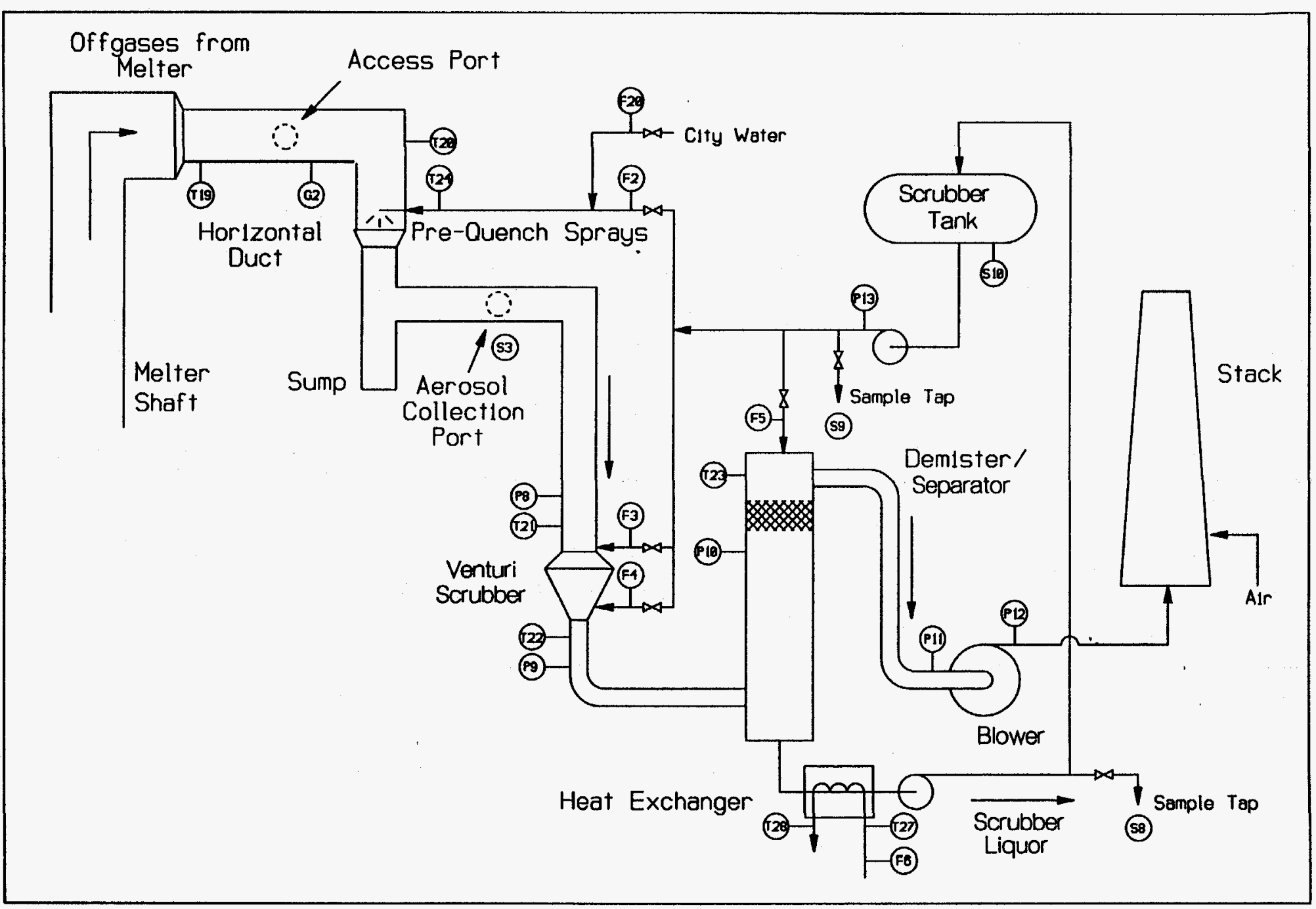

Figure 1.6 - Sampling and Process Measurement Locations in Offgas System 
The 1994 testing demonstrated the following:

1. The feasibility of using the plasma melter for vitrifying high-sodium liquid waste at high throughput (6 to 7 tonne/day equivalent rate of glass) with effective process and product control.

2. A practical and reliable feed system capable of supplying a consistent feed of LLW simulant and glassformers to the plasma melter ta provide a consistent glass product near the target composition.

3. The process data necessary to predict scaling of the plasma melter to 200 tonnes/day throughput of glass product.

4. The partitioning of the potentially volatile components $\mathrm{Cs}, \mathrm{Na}, \mathrm{K}, \mathrm{B}, \mathrm{Mo}$ (a Tc simulant), S, F, I, and $\mathrm{Cl}$ between the off-gas and the glass product.

5. Characterization of the offgas as to flowrate, composition $\left(\mathrm{N}_{2}, \mathrm{O}_{2}, \mathrm{CO}, \mathrm{CO}_{2}, \mathrm{H}_{2}, \mathrm{NO}_{x}\right.$ and $\mathrm{SO}_{2}$ ), and aerosol entrainment.

6. Successful processing of waste containing components such as $\mathrm{PO}_{4}, \mathrm{SO}_{4}, \mathrm{~F}$, and $\mathrm{Cl}$ which promote the formation of separated phases.

7. The requirements for feed processing, offgas treatment, and secondary waste disposal.

\subsection{OBJECTIVE OF STUDY}

The objective of this report is to provide the technical information necessary for Hanford personnel to evaluate the applicability, reliability and maintainability of the plasma fired vitrification process successfully tested by Westinghouse STC. The information required is provided in the form of a revised process description that minimizes maintenance and downtime and includes:

- Mass and energy balances;

- Equipment sizes and arrangement;

- Startup, operation, maintenance and shutdown cycle descriptions;

- Basis for scale-up to a 200 metric ton/day production facility.

In addition, equipment reliability estimates and maintenance requirements are provided which includes a list of failure modes, responses and consequences. Finally, operational requirements are provided including:

- Utilities;

- Feeds;

- Labor;

- Maintenance. 
WHC-SD-WM-VI-015 Revision 0

THIS PAGE INTENTIONALLY LEFT BLANK 


\section{CONCLUSIONS}

The following conclusions have been developed based on the results of the three preliminary Trial Heats, the 26-hour Demonstration Test, and subsequent engineering analysis:

1. A low-level waste vitrification facility can be constructed using Westinghouse Plasma Melter technology which can be readily scaled up to meet DOE's throughput requirement of 200 tonnes/day peak capacity, and which can produce a vitrified product meeting current specifications.

2. The facility would consist of three melters with a single module diameter of three meters, each supplied by ten plasma-fired vitrification tuyeres operating at a total of 18 megawatts, and each feeding two product delivery systems. The inherent modularity of the system allows scaleup from Phase I demonstrated production rates with minimal risk, while the small size minimizes radioactive system inventory. The total melter area footprint is estimated at 50 meters by 15 meters, with a required headroom of 6 meters.

3. The Westinghouse Plasma Vitrification Process is likely to be much more reliable than the $60 \%$ target established by Hanford, due to the inherent reliability of the commercially available process equipment and the modularity of the design. In addition, startup-shutdown procedures are simple and straightforward, and a supplemental glass reservoir will not be required.

4. The only feed pretreatment step suggested is waste feed evaporation to approximately 10 molar sodium content to improve the energy efficiency of the melting process, although vitrification of a more dilute feed is possible at lower throughput per melter. No other pretreatment is required, minimizing the amount of processing needed on the radioactive waste streams.

5. Evaporative concentration of scrubber system recycle is recommended, again to maximize individual melter throughput and provide the ultimate discharge point for water entering the system.

6. Volatilization of alkali metal species is identified as the major design issue (with the bulk of Phase I losses occurring as sodium borate). Improvement of volatiles retention efficiency will be dealt with by a number of strategies including use of a non-borosilicate glass composition, minimization of the shroud air feed to the tuyeres, injection nozzle design, and premixing of waste and glassformer to bind alkali. Sodium retention of $90-97 \%$ is anticipated, with the alkali carryover recovered in a recirculating scrubber system. Part of the scrubber liquor will be continuous withdrawn, concentrated by evaporation, and returned to the melter with fresh feed to maintain steady state concentrations of all components. 
7. Refractory damage will be minimized in the tuyere and crucible by use of cold-wall design, using a frozen layer of vitrified product to protect the metal wall, which is fabricated of a corrosion and temperature resistant alloy such as nickel. This approach not only minimizes maintenance requirements, but permits decontamination prior to maintenance by washing the wall using non-radioactive alkali feed. The pour spout area would remain refractory lined. The tuyeres will be separately flanged to the main melter body, to allow independent replacement.

8. Production of nitrogen oxides by the plasma arc will be mitigated by any of three strategies, including use of an arc working gas other than air, injection of methane into the working gas (air) at low concentration, or addition of ammonia to the shaft offgas. Selection of the optimal strategy depends on the results of future testing and economic factors.

9. Various system design changes (relative to the Phase I test configuration) are suggested to improve energy efficiency, simplify maintenance and decontamination efforts, reduce entrainment losses, and provide for easier startup with a frozen melter inventory.

10. Both frit and batch glassformer feed strategies have significant advantages; batch feed is less costly, but generates more offgas, is likely to be more difficult to control, consumes substantially more power, and requires a larger facility to accomplish the same waste throughput. Selection of the optimal strategy again depends both on economic assessment and the results of future testing (only frit feed was demonstrated during Phase I).

11. The ability to replace maintenance items on an individual torch (the field coils and electrodes) without halting operation of the melter will increase the overall availability of the Plasma Vitrification facility.

12. The maximum glass spill resulting from total failure of a melter would be about 0.7 tonnes of glass. This is much smaller than the maximum spills from conventional technologies (e.g., joule heated melter). 


\section{RECOMMENDATIONS}

1. Demonstration of Plasma Melter Operation at high volatiles retention with a non-borosilicate glass composition is proposed for Phase II, and is expected to achieve $90-97 \%$ retention of sodium in the glass product.

2. Demonstration of tuyere and/or crucible operation without refractory lining and using cold skull protection is recommended to verify this important design feature. The tuyere will be flanged to the body of the melter to allow independent replacement. This effort could either be part of Phase II, or carried out later as part of a final Pilot Plant demonstration activity.

3. Substantial or complete reduction of shroud gas is predicted to be possible with the cold skull tuyere concept, and is recommended for Phase II or Pilot Plant demonstration; this strategy is predicted to minimize offgas generation, decrease alkali carryover, and improve overall energy efficiency.

4. Other design changes to the tuyere are recommended as outlined in the Phase II proposal to improve energy efficiency, maintainability, and throughput.

5. Several strategies have been identified for abatement of $\mathrm{NO}_{\mathrm{x}}$ production by the plasma arc including operation with a gas other than air $\left(\mathrm{N}_{2}\right.$ or $\left.\mathrm{O}_{2}\right)$, catalytic reduction in the stack, injection of methane at low concentration into the arc and ammonia injection into the melter offgas stream. The latter two have not been quantified and are recommended for testing as part of the Phase II program.

6. Use of a water quench of the offgas is recommended to reduce or eliminate accumulation of solids in the offgas ducts.

7. Since batch glassformer feed (as compared to frit feed) has significant economic advantages, its operating characteristics in the Plasma Melter should be demonstrated during Phase II, to permit quantification of the operational issues associated with the two alternative glassformer strategies.

8. The material and energy balances presented in the current report should be updated based upon detailed analysis of Phase I chemistry results as soon as these are available. 
WHC-SD-WM-VI-015 Revision 0

THIS PAGE INTENTIONALLY LEFT BLANK 


\section{PROCESS DEFINITION}

This section describes the basis and resulting design for the full scale process. Included are the following items:

1. Process specifications;

2. Description of the process with modifications based upon the results of the successful 26-hour Phase I Demonstration Test;

3. Mass and energy balance for process;

4. Process layout;

5. Description of startup, operation, maintenance and shutdown modes of operation;

6. Scale-up issues;

7. Description of feed systems; and

8. Description of off-gas treatment system.

\subsection{PLANT MELTER DESIGN CONCEPT}

The plasma based melter system design is based on providing a process to produce a high quality, vitrified low level waste product, in a mechanically safe and easy to operate facility, with as low as achievable radioactive exposures to personnel, and with minimal capital and operating costs. These design goals are readily achievable using the Westinghouse Plasma Torch because:

1. Large amounts of energy can be transmitted to the low level waste and glassforming frit in a high energy density form (plasma gas) which has an extremely high rate of heat transfer;

2. The plasma gas can be produced in small, reliable, easily maintainable Westinghouse Plasma Torches, which can be located in either radioactively clean or slightly contaminated portions of the facility;

3. The waste and glassformers are intimately mixed and melted over a short (tens of milliseconds) time period, which provides for easy control of the glass composition.

4. The inventory of glass in the melter is minimized because of the short overall residence time required.

5. Shutdown and restart are simple and straightforward operations.

Westinghouse can provide this process with assurance based on over 20 years of experience with Plasma Technology and its application to melting a wide range of materials in industrial scale facilities. 


\subsubsection{Process Specifications}

The performance specifications as provided by Hanford are outlined in Table 4.1, with references to the original Request for Proposal (RFP) ${ }^{*}$; its Statement of Work (SOW; RFP Section 3), the Technical Selection Criteria (TSC; RFP Section 4), and a communication from M. J. Bowman of Westinghouse Hanford clarifying some of the design bases for this study. These performance specifications provide the basis for the process also listed in Table 4.1. The actual design basis was determined by assuming that the instantaneous production rate is $\mathbf{2 0 0}$ metric tons per day of glass. Hanford has allowed $40 \%$ of this capacity for maintenance outages or other downtime.

The design rate is conservative since:

- The assumed efficiency is lower than what will be actually achieved as shown by the Demonstration Test where at 1.5 megawatts electric (MWe) the efficiency achieved was $83.9 \%$, and torch efficiency increases as the power rating increases.

- As discussed below, lower or no shroud gas flow will be proposed which will decrease the power consumption by up to $265 \mathrm{kWe}$.

\section{Table 4.1. Vitrification Performance and Process Specifications}

\begin{tabular}{|l|l|l|}
\hline $\begin{array}{l}\text { Performance } \\
\text { Specifications }\end{array}$ & & \\
\hline Throughput: & $\begin{array}{l}200 \text { metric tonnes per day of } \\
\text { glass peak }\end{array}$ & $\begin{array}{l}\text { Bowman, } \\
\text { page 2 }\end{array}$ \\
\hline Waste Loading: & $25 \%$ calcined oxides & SOW, page 13 \\
\hline Glass Melt Temperature: & 1100 to $1450^{\circ} \mathrm{C}$ & TSC, page 2 \\
\hline Process Specifications & 3 melters & \\
\hline Number of Melters: & 10 torches & \\
\hline Torches per Melter: & $2.3 \mathrm{MWe}$ at $85 \%$ efficiency & \\
\hline $\begin{array}{l}\text { Maximum Power per } \\
\text { Torch: }\end{array}$ & $2.0 \mathrm{MWe}$ at 83\% efficiency & \\
\hline $\begin{array}{l}\text { Operating Power per } \\
\text { Torch: }\end{array}$ & $\begin{array}{l}\text { Maximum Glass Capacity } \\
\text { per Torch: }\end{array}$ & $5.7 \mathrm{~kg} / \mathrm{min}$ \\
\hline $\begin{array}{l}\text { Design Glass Capacity per } \\
\text { Torch: }\end{array}$ & $5.0 \mathrm{~kg} /$ min & $\begin{array}{l}\text { Bowman, } \\
\text { page 2 }\end{array}$ \\
\hline $\begin{array}{l}\text { Design Outage Time: } \\
\text { page 2 }\end{array}$ \\
\hline Design Basis: & $40 \%$ per year \\
\hline
\end{tabular}

- "Evaluation of Melter System Technologies for Vitrification of High-Sodium Content Low-Level Radicactive Wastes," Westinghouse Hanford Company Request for Proposal W-045792-LR, February 25, 1994.

$\dagger$ M. J. Bowman, 'Low-Level Waste Melter Technology Demonstration Subcontract MMI-SVV-384212, Request for Technical Information," Westinghouse Hanford Company, January 6, 1995. 


\subsubsection{Description of Process}

The process as originally proposed has been slightly modified to take into account lessons learned concerning phenomena observed during the three Phase I Trial Heats and the 26-hour Demonstration Test. These phenomena and the resulting changes are as follows:

1. Observed volatilization of sodium borates. The apparent volatility of $\mathrm{NaBO}_{2}$ may cause problems in the off-gas system, and is believed to be the primary cause of incomplete retention of alkali in the glass product. The change which is incorporated is the elimination of boron from the glass formulation by replacing boron oxide by an appropriate mixture of $\mathrm{SiO}_{2}, \mathrm{Li}_{2} \mathrm{O}$, and $\mathrm{CaO}$. The higher melter operating temperature is easily accommodated by the Plasma Melter. The higher melting point of the glassformer mixture will make production of frit more difficult, and increase the cost of the material relative to batch glassformer material, however. The economic tradeoffs of frit versus batch are discussed in Section 4.2 below.

2. Potential for wear on progressive cavity pump from highly abrasive frit. While highly effective at delivering the waste-glassformer slurry to the tuyere, this piece of equipment might be expected to be a high maintenance item; removing it from contact with radioactive materials would therefore significantly improve maintainability. The change which is incorporated is to pre-mix a high solids slurry of glass frit or batch glassformers in the cold chemical areas, which is then pumped into the radioactive area and mixed with the waste prior to injection in front of the torch. This will allow the pumps to be operated and maintained in a non-radioactive area.

3. Potential for refractory wear from sodium corrosion and frit abrasion. As discussed in the Phase I test reports, significant loss of tuyere refractory lining took place during testing. However, the rate of loss decreased to nearly zero, suggesting that the water-cooled walls of the tuyere had created a self-healing, steady-state skull coating of frozen, vitrified material. Given these results, the change which is incorporated is the elimination of the refractory and replacement with a water cooled wall only. This approach will form a cold skull of glassy material on the walls for both thermal insulation and corrosion/erosion protection, will eliminate refractory maintenance, and will allow fast in-place decontamination of the walls and tuyere of the melter. The only exception would be the roof and walls of the pour spout area, which would use a high density alumina refractory facing over fibrous insulation. Replacement of the refractory in this area would probably not be required over the life of the melter due to the lack of significant gas and solids flow, and the fact that there would be little if any sodium oxide evaporation at this point.

4. Potential problems of reheating a cold crucible full of glass. Although shutdown and restart after roughly one hour of downtime was demonstrated without incident during Phase I Demonstration Testing, restart of a fully frozen crucible in the current Plasma Melter configuration could be difficult if the glass were largely opaque. This is because in the Phase I configuration the primary mechanism for 
heat transfer from the plasma plume to the crucible is radiation, and radiative heat transfer is highly inefficient if the glass is very dark colored or opaque. The change which is incorporated is the increase in the angle of the tuyere to allow direct impingement of the torch and glass plumes on the crucible surface. This will provide for both convective and radiative heating of the crucible and should decrease carryover. In addition, electrical heating elements are suggested for the crucible (either embedded in the refractory if this is used, or mounted on the exterior if a coldskull design is used), such as is common practice in the commercial glassmaking industry.

5. Dispersion of the molten glass plume due to high shroud gas flow. The shroud gas flow originally designed to protect the tuyere refractory creates a violent flow circulation pattern in the tuyere which is believed to disperse the molten glass product into a fine mist, encouraging aerosolization. In addition, recirculation eddies created in the region of the torch cause partially calcined material to deposit on the snout of the torch, which in a radioactive environment would complicate removal of the torch for maintenance. A decrease or elimination of the shroud gas flow is proposed, along with changes in tuyere geometry. A decrease in the shroud gas flow will increase the energy efficiency and reduce the dispersion of the glass melt into fine droplets.

The modified process is shown in Figures 4.1 and 4.2. Based on the test parameters and results of the 26-hour Demonstration Test shown in Table 4.2, a preliminary material and energy balance was developed and is shown in Table 4.3. Although the balances summarized here are specific to a particular feed rate and waste and glassformer chemistry, the Plasma Vitrification process is very flexible since:

1. Power input can be varied over a wide range to account for changes in glass composition and feed water content.

2. Inventory of pre-mixed feed, semi-melted glass and melted glass is small, reducing the response time to changes in the feed chemicals and waste.

3. Since radiation and convection from the torch gas plume are the main methods for heat transfer, the plasma melting process has low sensitivity to waste chemical components such as reducible metals.

4. Foaming of the glass melt due to carbonate and nitrate decomposition reactions and the oxidation of organics is eliminated, since these reactions occur in the tuyere before the glass melt reaches the crucible. 
WHC-SD-WM-Vh-015 Revision 0

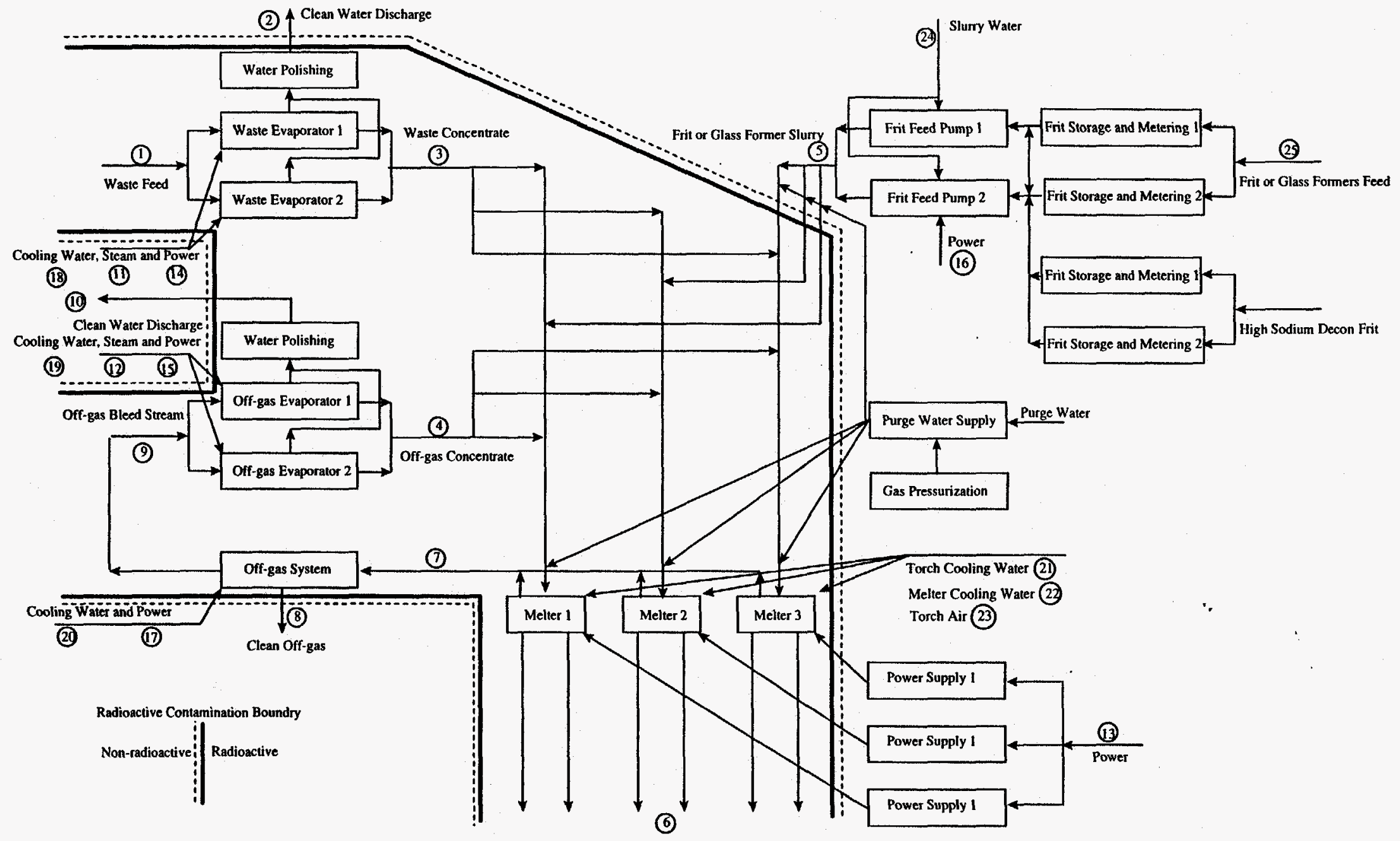

Figure 4.1 - Block Diagram of Westinghouse Low Level Waste Vitrification Facility 

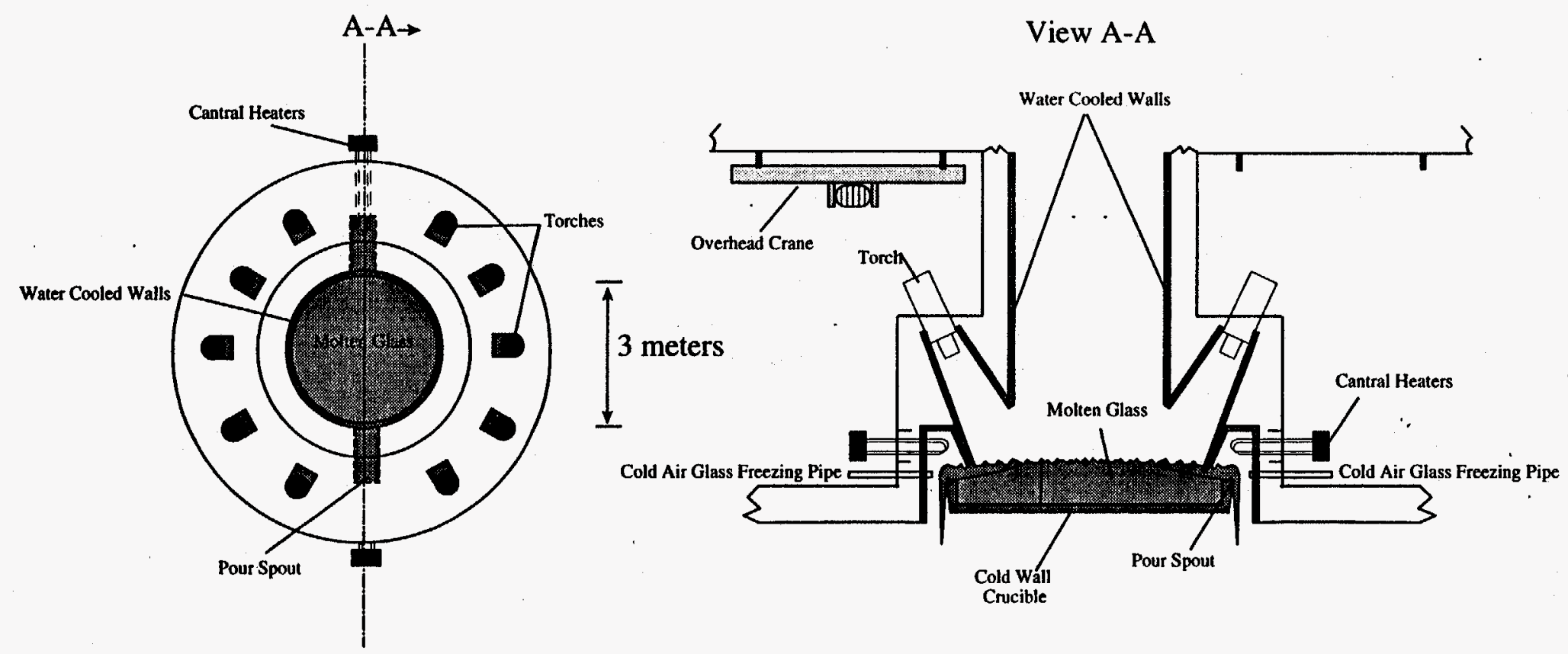

Figure 4.2 - Diagram of Tuyere and Crucible Areas of the Westinghouse Vitrification Reactor 
Table 4.2 - Process Specifications for 26-Hour Demonstration Test

\begin{tabular}{|l|l|}
\hline Simulant Feed Rate: & $3.71 \mathrm{~V} / \mathrm{min}$ \\
\hline Calcined Waste Feed Rate: & $1.63 \mathrm{~kg} / \mathrm{min}(76 \% \mathrm{Na}, \mathrm{O})$ \\
\hline Glass Frit Feed Rate: & $3.95 \mathrm{~kg} / \mathrm{min}$ \\
\hline Total Glass Feed Rate (No losses): & $5.58 \mathrm{~kg} / \mathrm{min}$ \\
\hline Total Glass Rate (Actual): & $4.91 \mathrm{~kg} / \mathrm{min}$ \\
\hline Total Glass Production Time: & $1400 \mathrm{~min}$ \\
\hline Torch Power: & $1532 \pm 54 \mathrm{kWe}$ \\
\hline \multicolumn{1}{|c|}{ Current } & $1676 \pm 46 \mathrm{amp} \mathrm{DC}$ \\
\hline \multicolumn{1}{|c|}{ Voltage } & $917 \pm 17 \mathrm{volts} \mathrm{DC}$ \\
\hline Torch Efficiency: & $83.9 \%$ \\
\hline $\begin{array}{l}\text { Glass Spout Immersion Thermocouple } \\
\text { Temperature: }\end{array}$ & $1273 \pm 54{ }^{\circ} \mathrm{C}$ \\
\hline Torch Air Flow: & $4.05 \pm 0.17 \mathrm{std}-\mathrm{m}^{3} / \mathrm{min}$ \\
\hline Shroud Air Flow: & $10.4 \pm 1.4 \mathrm{std}-\mathrm{m}^{3} / \mathrm{min}$ \\
\hline Total Offgas Flow: & $18.0 \mathrm{std}-\mathrm{m}^{3} / \mathrm{min}$ \\
\hline Cooling Water Flows: & $564 \mathrm{~L} / \mathrm{min}$ total \\
\hline Tuyere: & $242 \pm 3 \mathrm{~L} / \mathrm{min}$ \\
\hline Torch Electrode: & $62.1 \pm 0.4 \mathrm{~L} / \mathrm{min}$ \\
\hline Melter Shell: & $260 \pm 1 \mathrm{~L} / \mathrm{min}$ \\
\hline
\end{tabular}




\title{
Table 4.3(a) - Mass and Energy Balance for the Westinghouse Plasma Melter Process \\ (Non-Borosilicate Frit Glassformer)
}

\author{
Assumptions \\ Carryover of solids from melter \\ Waste feed solids content \\ Waste evaporator concentrate solids \\ Calcine solids in waste concentrate \\ Water in waste concentrate \\ Frit slurry solids \\ Glass rate \\ Number of torches \\ Evaporate heat load \\ Solids in off-gas solution \\ Plug to torch thermal efficiency \\ Torch power required \\ Cooling water temperature rise \\ Gas temperature in Scrubber \\ Gas from Glassformer Calcination \\ No shroud gas flow
}

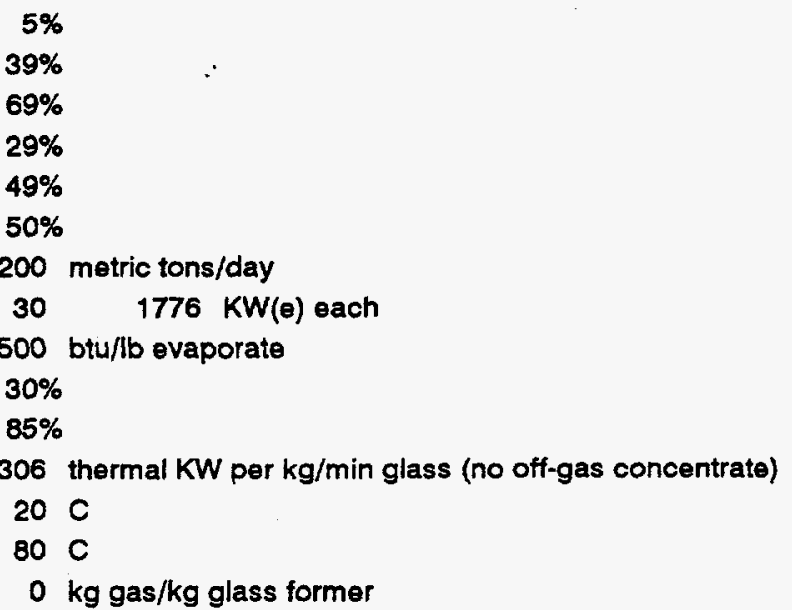

\begin{tabular}{cl} 
Stream & \multicolumn{1}{c}{ Stream Name } \\
\# & \\
1 & Waste Feed \\
2 & Clean Water: Waste Evaporator \\
3 & Waste Concentrate \\
4 & Off-gas Concentrate \\
5 & Frit Slurry \\
6 & Glass \\
7 & Off-gas \\
8 & Gas to Stack \\
9 & Off-gas Bleed Stream \\
10 & Clean Water: Off-gas Evaporator \\
11 & Steam: Waste Evaporator \\
12 & Steam: Otf-gas Evaporator \\
13 & Power: Torches \\
14 & Power: Waste Evaporator \\
15 & Power: Off-gas Evaporator \\
16 & Power: Frit Pump \\
17 & Power: Off-gas System Fans and Pumps \\
18 & Cooling Water: Waste Evaporator \\
19 & Cooling Water: Off-gas Evaporator \\
20 & Cooling Water: Off-gas System \\
21 & Cooling Water: Plasma Torches \\
22 & Cooling Water: Plasma Melters \\
23 & Air to Plasma Torches \\
24 & Water: Frit Slurry \\
25 & Frit Feed \\
& \\
& \\
& \\
1 &
\end{tabular}

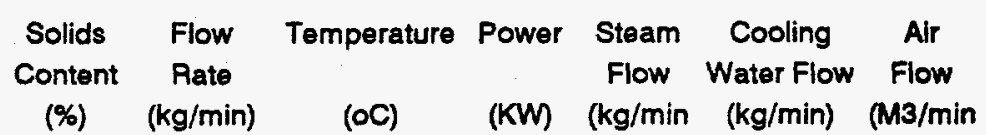

Frit Cost $(\$ / \mathrm{kg})$

Frit Rate ( $\mathrm{kg} / \mathrm{kg}$ glass)

Frit Cost/kg Glass

$\begin{array}{ccc}(\%) & (\mathrm{kg} / \mathrm{min}) & (0 \mathrm{C}) \\ 39 \% & 215 & 20 \\ 0 \% & 93 & 55 \\ 69 \% & 122 & 100 \\ 30 \% & 33 & 100 \\ 50 \% & 208 & 20 \\ 100 \% & 139 & 1300 \\ 3 \% & 329 & 130 \\ 0 \% & 249 & 110 \\ 12 \% & 79 & 80 \\ 0 \% & 46 & 55 \\ 0 \% & 140 & 200 \\ 0 \% & 69 & 200\end{array}$

20

55

100

100

20

1300

1300

110

80

55

200

200

140

69

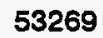

103

51

55

405

$0 \% \quad 3886 \quad 35$

3886

1927

26300

5737

3991

$105 \quad 20$

$0 \% \quad 104 \quad 20$

$100 \% \quad 104 \quad 20$

\begin{tabular}{llcccc}
$\$ 2.00$ & Utilities Totals & 53883 & 209 & 41841 & 122 \\
3.00 & Estimated Unit Costs & $\$ 0.05$ & $\$ 0.011$ & $\$ 0.003$ & $\$ 0.01$ \\
$\$ 6.00$ & Estimated Costs/hr & $\$ 2.694$ & $\$ 138$ & $\$ 7.531$ & $\$ 73$ \\
& Estimated Cost/kg Glass & $\$ 0.32$ & $\$ 0.02$ & $\$ 0.90$ & $\$ 0.01$ \\
\multicolumn{7}{l}{ Total Utilities Cost/kg Glass } & & & $\$ 1.25$
\end{tabular}


Table 4.3(b) - Mass and Energy Balance for the Westinghouse Plasma Melter Process

(Borosilicate Frit Glassformer)

Assumptions

Carryover of solids from melter

Waste feed solids content

Waste evaporator concentrate solids

Calcine solids in waste concentrate

Water in waste concentrate

Frit slurry solids

Glass rate

Number of torches

Evaporate heat load

Solids in off-gas solution

Plug to torch thermal efficiency

Torch power required

Cooling water temperature rise

Gas temperature in Scrubber

Gas from Glassformer Calcination

No shroud gas flow

\begin{tabular}{|c|c|}
\hline $\begin{array}{c}\text { Stream } \\
\#\end{array}$ & Stream Name \\
\hline 1 & Waste Feed \\
\hline 2 & Clean Water: Waste Evaporator \\
\hline 3 & Waste Concentrate \\
\hline 4 & Off-gas Concentrate \\
\hline 5 & Frit Slurry \\
\hline 6 & Glass \\
\hline 7 & Off-gas \\
\hline 8 & Gas to Stack \\
\hline 9 & Off-gas Bleed Stream \\
\hline 10 & Clean Water: Off-gas Evaporator \\
\hline 11 & Steam: Waste Evaporator \\
\hline 12 & Steam: Off-gas Evaporator \\
\hline 13 & Power: Torches \\
\hline 14 & Power: Waste Evaporator \\
\hline 15 & Power: Off-gas Evaporator \\
\hline 16 & Power: Frit Pump \\
\hline 17 & Power: Off-gas System Fans and Pum \\
\hline 18 & Cooling Water: Waste Evaporator \\
\hline 19 & Cooling Water: Off-gas Evaporator \\
\hline 20 & Cooling Water: Off-gas System \\
\hline 21 & Cooling Water: Plasma Torches \\
\hline 22 & Cooling Water: Plasma Melters \\
\hline 23 & Air to Plasma Torches \\
\hline 24 & Water: Frit Slurry \\
\hline 25 & Frit Feed \\
\hline
\end{tabular}

\begin{tabular}{|c|c|c|c|c|c|c|}
\hline $\begin{array}{c}\text { Solids } \\
\text { Content } \\
\text { (\%) }\end{array}$ & $\begin{array}{c}\text { Flow } \\
\text { Rate } \\
(\mathrm{kg} / \mathrm{min})\end{array}$ & Temperature & Power & $\begin{array}{c}\text { Steam } \\
\text { Flow } \\
\text { (kg/min }\end{array}$ & $\begin{array}{l}\text { Cooling } \\
\text { Water Flow } \\
\text { (kg/min) }\end{array}$ & $\begin{array}{c}\text { Air } \\
\text { Flow } \\
\text { (M3/min }\end{array}$ \\
\hline $39 \%$ & 215 & 20 & & & & \\
\hline $0 \%$ & 93 & 55 & & & & \\
\hline $69 \%$ & 122 & 100 & & & & \\
\hline $30 \%$ & 111 & 100 & & & & \\
\hline $50 \%$ & 208 & 20 & & & & \\
\hline $100 \%$ & 139 & 1300 & & & & \\
\hline $8 \%$ & 406 & 1300 & & & & \\
\hline $0 \%$ & 249 & 110 & & & & \\
\hline $21 \%$ & 157 & 80 & & & & \\
\hline $0 \%$ & 46 & 55 & & & & \\
\hline $0 \%$ & 140 & 200 & & 140 & & \\
\hline $0 \%$ & 69 & 200 & & 69 & & \\
\hline & & & 61944 & & & \\
\hline & & & 103 & & & \\
\hline & & & 51 & & & \\
\hline & & & 55 & & & \\
\hline$s$ & & & 405 & & & \\
\hline $0 \%$ & 3886 & 35 & & & 3886 & \\
\hline $0 \%$ & 1927 & 35 & & & 1927 & \\
\hline $0 \%$ & 31594 & 35 & & & 31594 & \\
\hline $0 \%$ & 6671 & 35 & & & 6671 & \\
\hline $0 \%$ & 3991 & 35 & & & 3991 & \\
\hline $0 \%$ & 105 & 20 & & & & 122 \\
\hline $0 \%$ & 104 & 20 & & & & \\
\hline $100 \%$ & 104 & 20 & & & & \\
\hline$\$ 2.00$ & \multicolumn{2}{|c|}{ Utilities Totals } & 62557 & 209 & 48069 & 122 \\
\hline 3.00 & \multicolumn{2}{|c|}{ Estimated Unit Costs } & $\$ 0.05$ & $\$ 0.011$ & $\$ 0.003$ & $\$ 0.01$ \\
\hline \multirow[t]{3}{*}{$\$ 6.00$} & \multirow{2}{*}{\multicolumn{2}{|c|}{$\begin{array}{l}\text { Estimated Costs/hr } \\
\text { Estimated Cost } / \mathrm{kg} \text { Glass }\end{array}$}} & $\$ 3,128$ & $\$ 138$ & $\$ 8,652$ & $\$ 73$ \\
\hline & & & $\$ 0.38$ & $\$ 0.02$ & $\$ 1.04$ & $\$ 0.01$ \\
\hline & \multicolumn{5}{|c|}{ Total Utilities Cost/kg Glass } & $\$ 1.44$ \\
\hline
\end{tabular}

Frit Cost $(\$ / \mathrm{kg})$

Frit Rate (kg/kg glass)

Frit Cost/kg Glass

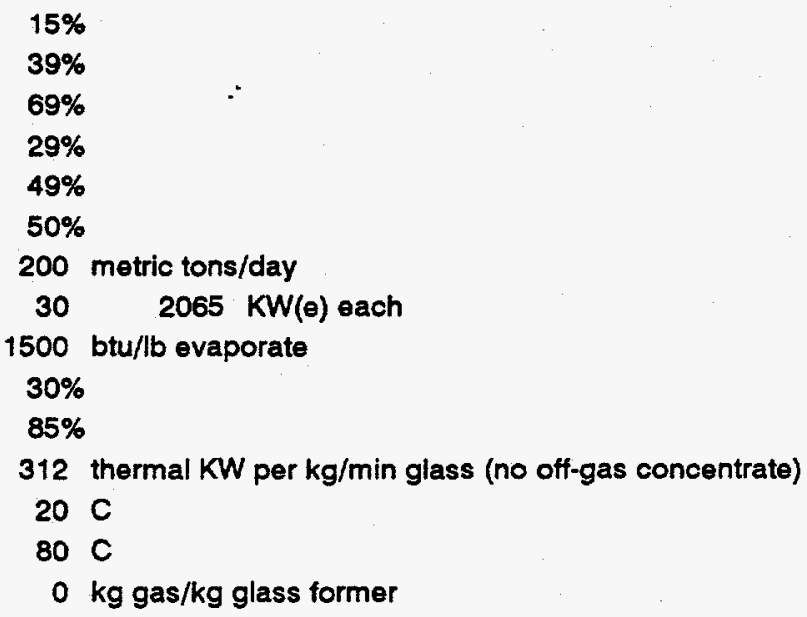




\section{Table 4.3(c) - Mass and Energy Balance for the Westinghouse Plasma Melter Process \\ (Non-Borosilicate Batch Glassformer)}

Assumptions

Carryover of solids from melter

Waste feed solids content

Waste evaporator concentrate solids

Calcine solids in waste concentrate

Water in waste concentrate

Frit slurry solids

Glass rate

Number of torches

Evaporate heat load

Solids in off-gas solution

Plug to torch thermal efficiency

Torch power required

Cooling water temperature rise

Gas temperature in Scrubber

Gas from Glassformer Calcination

No shroud gas flow

\begin{tabular}{cl} 
Stream & \multicolumn{1}{c}{ Stream Name } \\
\# & \\
1 & Waste Feed \\
2 & Clean Water: Waste Evaporator \\
3 & Waste Concentrate \\
4 & Off-gas Concentrate \\
5 & Frit Slurry \\
6 & Glass \\
7 & Off-gas \\
8 & Gas to Stack \\
9 & Off-gas Bleed Stream \\
10 & Clean Water: Otf-gas Evaporator \\
11 & Steam: Waste Evaporator \\
12 & Steam: Off-gas Evaporator \\
13 & Power: Torches \\
14 & Power: Waste Evaporator \\
15 & Power: Off-gas Evaporator \\
16 & Power: Frit Pump \\
17 & Power: Off-gas System Fans and Pumps \\
18 & Cooling Water: Waste Evaporator \\
19 & Cooling Water: Otf-gas Evaporator \\
20 & Cooling Water: Otf-gas System \\
21 & Cooling Water: Plasma Torches \\
22 & Cooling Water: Plasma Melters \\
23 & Air to Plasma Torches \\
24 & Water: Frit Slurry \\
25 & Frit Feed \\
& \\
& Batch Cost (\$/kg) \\
& Batch Rate (kg/kg glass) \\
& \\
& \\
&
\end{tabular}

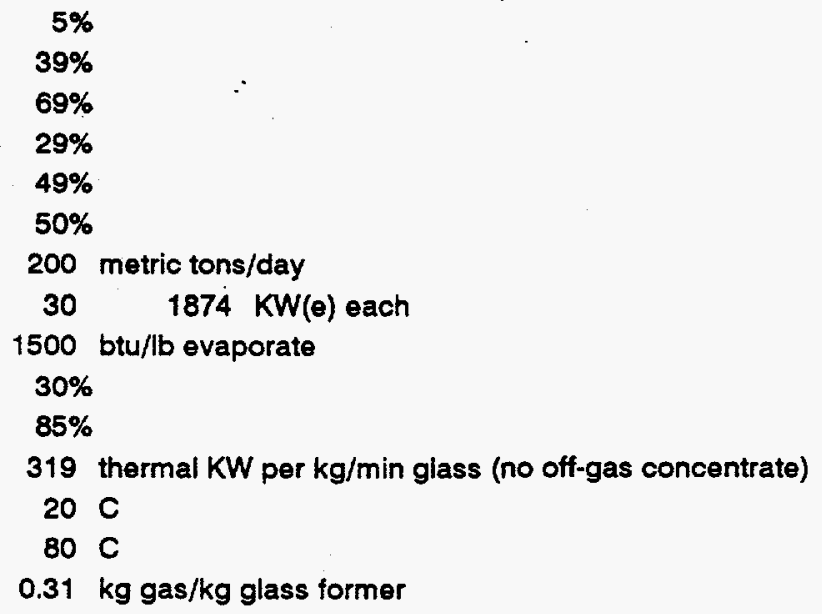


Referring to Figure 4.1, the waste (1) is fed to the waste evaporator where the sodium concentration is increased to about 10M. The water evaporate is sent through a zeolite guard column to remove cesium or iodine carryover and discharged as a clean stream (2). The waste concentrate (3) is mixed with the off-gas concentrate (4) and glassformer slurry (5) and injected into the hot gas plume of the plasma torch. Molten glass is withdrawn from the vitrification unit (6) and poured into the waste containers. The offgases (7) are scrubbed to remove solids and release clean gas (8). A side stream from the offgas scrubbers (9) is sent to the offgas evaporator where the total solids concentration is increased to about $30 \%$ by weight. The water evaporate is sent through a zeolite guard column to remove cesium, iodine, technetium, and ruthenium carryover and discharged as a clean stream (10). The concentrate bottoms (4) are recycled back to the feed stream to the plasma torch. Utility connections include:

- Steam (11) to the waste evaporator.

- Steam (12) to the off-gas evaporator.

- Power (13) to the torch power supply.

- Power (14) to the waste evaporator recirculation pump.

- Power (15) to the offgas evaporator recirculation pump.

- Power (16) to the frit slurry pump.

- Power (17) to the offgas system.

- Cooling water (18) to the waste evaporator.

- Cooling water (19) to the offgas evaporator.

- Cooling water (20) to the offgas system.

- Cooling water (21) to the plasma torches.

- Cooling water (22) to the walls of the plasma fired melter.

- Air (23) to the plasma torch.

Glassformer slurry is made up by adding either frit or bulk glassformer components (25) and slurry water (24) to the frit pump. A parallel glassformer system will also be used to supply a high sodium frit or bulk glassformer feed (also 24) when decontamination of the plasma melter is desired. An air pressurized purge water system is provided to clear slurry feed lines before shutdown; this is important since chemical reaction between the caustic waste liquid and glassformer materials can result in hydrolysis and formation of solid blockages if allowed to stand in process lines. Figure 4.3 shows the feed and purge header arrangement. No valve has both waste and frit/glassformer going through it to prevent plugging due to reaction between frit/glassformer and waste. All lines have purge water connections to allow individual flushout of the line. In addition, only 1 valve per torch feed line is in the radioactive zone.

\subsubsection{Process Layout}

Detail of the melter area is shown in Figure 4.4. The melter facility will consist of three islands of plasma melters with common feed evaporator, glassformer feed, offgas system, offgas recycle evaporator, and power supply areas. Each melter will feed two 


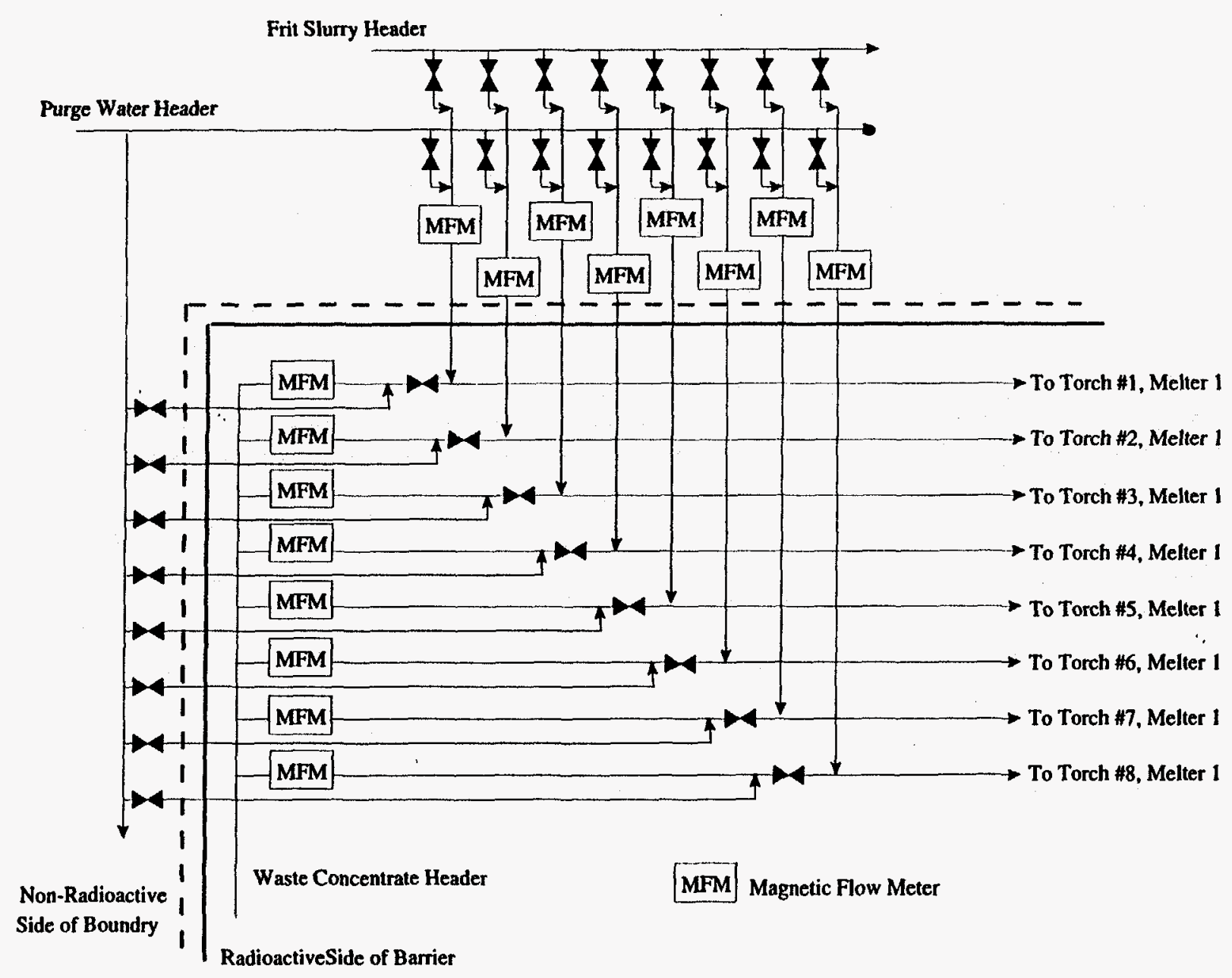

Figure 4.3 - Arrangement of Feed and Purge Line Header 


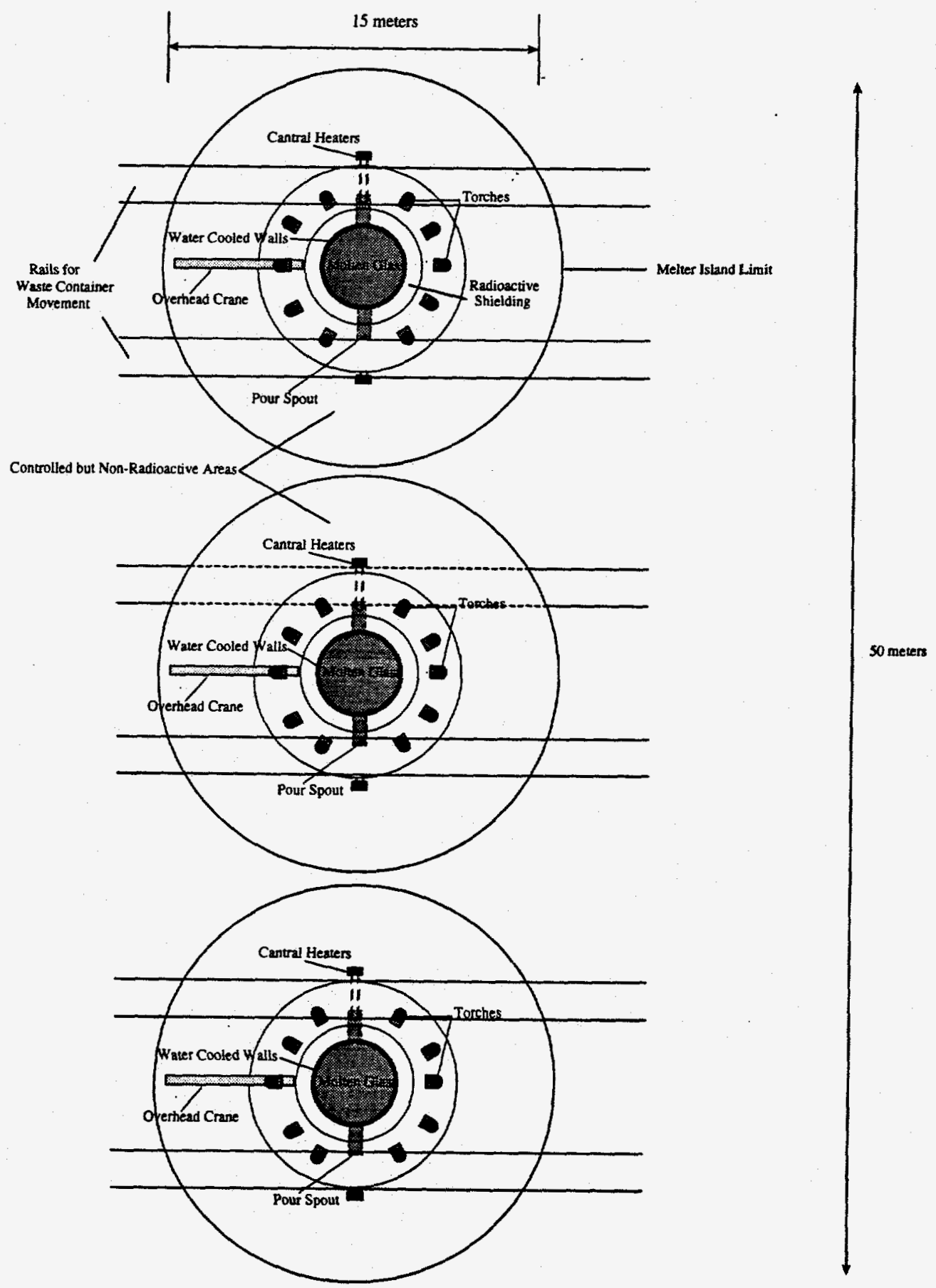

Figure 4.4 - Proposed Layout of Westinghouse Low Level Waste Vitrification Facility 
pouring spouts. This will allow the crucible of the melter to act as the holdup volume for the glass as a waste container is changed out of one pouring spout. Alternatively, a single spout can be used if sufficient volume is allowed for in the crucible.

\subsection{PROCESS SCALE-UP}

Scaleup of the Westinghouse Plasma Vitrification Process based on the performance achieved during the 26-hour Demonstration Test is straightforward and reliable since one full scale melting station (represented by a plasma torch) has been demonstrated at about between 4.8 and $5.1 \mathrm{~kg} / \mathrm{min}$ (6.9 to 7.3 tonnes/day) glass production at $1525 \mathrm{kWe}$ electrical power. This demonstrated throughput is slightly greater than the desired full throughput rate of $4.6 \mathrm{~kg} / \mathrm{min}$ per torch (200 tonnes/day processed by 30 torches). With the additional evaporative load from glassformer slurry feed and recycle of volatiles from the scrubber system, the calculated per-torch power with 30 torches is $1870 \mathrm{kWe}$, which is below the recommended design point $(2000 \mathrm{kWe})$ for continuous operation of the Westinghouse Marc-11 torch.

The basis for scaling to the full plant is therefore only a matter of replicating this single plasma melting station until the desired full scale output is achieved. No adverse effects are expected from scaling the vitrification process from a glass rate of about 7.1 metric tonnes per day to the required 200 metric tonnes per day of rated capacity. In fact, better performance of the system is expected due to the following effects:

1. A better energy performance is expected, since a lower surface-to-volume ratio in each plasma melter limits energy losses.

2. Lower volatiles loss $(5 \%)$ is expected due to the use of a reduced boron frit formulation.

3. A better glass quality is expected due to the increased residence time in the crucible, since scaleup from a 0.76-meter diameter melter with a single torch (comparable to the existing Pilot Plant) to a 3-meter melter with six torches increases the ratio of crucible surface area to throughput.

4. The same scaling argument applies to the offgas velocity in the melter shaft; increasing the area/throughput ratio and elimination of shroud gas flow reduces the offgas velocity from its demonstrated Phase I value $\left(40 \mathrm{std}-\mathrm{m}^{3} / \mathrm{min} / \mathrm{m}^{2}\right)$ to only $16 \mathrm{std}$ $\mathrm{m} / \mathrm{min} / \mathrm{m}^{2}$, which should decrease volatile losses and entrainment.

Two negative effects due to changes from the Demonstration Test configuration impact the energy efficiency of the process. Use of cold walls to form a protective skull of glass in place of a refractory coating may result in greater conductivity losses to the cooling water. The thermal conductivities of solidified glass and typical refractories do not differ greatly, however, so that this effect may be minimal. However, the expected elimination of refractory maintenance which this change will result in cost and productivity gains which are expected to far outweigh the increased energy costs.

The second impact concerns the use of batch feed in place of frit. Clearly, energy is required to melt the glassformers at some point in the process, whether in a separate facility providing glassformer frit, or in the radioactive glass melter itself. If frit feed is selected, the energy associated with raising the calcined glassformers to their melting 
point must be expended twice; additional processing is required to comminute the resulting glassformer solids. And a separate frit smelting facility is required, adding capital cost to the overall system. However, other factors argue in favor of use of frit. All of the frit production facilities are non-radioactive, so that maintenance is straightforward and offgas handling is of no consequence. The offgases associated with calcination of batch glassformers such as calcium and lithium carbonates do not become part of the stream which must be processed for radioactive contaminant removal, which is a significant savings in both capital and operating cost. It is believed that feeding frit as opposed to batch materials into the waste melter will make the vitrification process easier, reducing the required residence time, and probably producing a more homogeneous and reproducible product. In addition, because of the energy required to calcine the batch glassformer materials, the throughput per torch/tuyere is reduced substantially, making the size of the radioactive melting facility and its containment canyon larger by up to one-third (addition of a fourth melter). Selection of frit versus batch must therefore be made based on a careful assessment of the economic and operability factors, which will in turn depend on the detailed design and cost estimates.

\subsection{SUPPLEMENTAL GLASS RESERVOIR}

No supplemental glass reservoir is required or currently desired. This is due to the following considerations:

1. The Westinghouse Plasma Vitrification Reactor already produces a high quality glass as measured by durability testing with the Product Consistency Test (PCT), due to the good mixing of the waste and glassforming materials in the tuyere and the residence time in the crucible. (Whether the current product is acceptable as a final wasteform cannot be determined until waste acceptance criteria have been established for LLW glass).

2. The increased volume of a glass reservoir would increase the response time of the process to process changes and increase the volume of contaminated glass held in the process.

3. The elimination of an additional process vessel will result in reduced operational difficulties, capital costs and maintenance costs.

\subsection{PERIODIC MELTER OPERATION}

Periodically stopping and restarting the melter feed will pose no significant operating problems for the Westinghouse Plasma Melter. While idling the melter at reduced torch power should pose no operating problems, experience in the glass industry has indicated that the more volatile components such as sodium and cesium may tend to slowly evaporate from the hot surface layer of the melter. Other than this possible effect, there is no reason why the plasma melter could not be idled hot for an indefinite time period. Restart after a one-hour idle with no feed or plasma torch input power was 
demonstrated during the final Phase I Demonstration Test, with no operational difficulties; thermal steady state was reestablished within an hour of restart.

The final crucible and product extraction system design should provide for moreor-less complete removal or draining of molten glass in the case of a complete system shutdown, since remelting of a completely frozen crucible full of glass does pose some operational difficulties. Design modifications relative to the current Pilot Plant configuration in which the angle of the vitrification tuyeres is increased to provide a more direct impingement of the plasma plume on the crucible bottom should alleviate remelting problems and permit easy restart even with a fully frozen crucible.

\subsection{FEED SYSTEM DEFINITION}

The proposed feed system is shown on Figure 4.5. The feed system consists of three portions:

1. The low level waste feed evaporator. This unit concentrates the inlet feed from the expected $6 \mathrm{Molar}$ to about $10 \mathrm{M}$ sodium. This final value is the same concentration as was demonstrated in the 26-hour Demonstration Test and the three Trial Heats. Although not required, this evaporator will reduce the power requirements in the plasma vitrification area (reducing the number of required torches and the size of the plasma processing area), provide holdup time for the feed to allow some smoothing of feed concentration variations, and serve as a buffer between the tank farms and the vitrification process. Evaporation to $10 \mathrm{M}$ sodium concentration is not expected to result in significant precipitation and subsequent fouling problems, although this factor may vary from one waste composition to another. If evaporation is not used, a batch tank to provide holdup time for the feed and to serve as a buffer between the tank farms and the vitrification process can be used.

2. The glassformer batch chemical or frit feed system. This system supplies a slurry of glass forming materials to be pre-mixed with the feed before being injected into the torch plume. The glassformer delivery system is located in the nonradioactive portion of the facility and consists of dry materials storage, batch makeup, powder feed, and progressive cavity pumps for forming and transporting the slurry. As indicated above, providing the required delivery pressure for the glassformer slurry with a strictly non-radioactive slurry pump greatly reduces maintenance difficulties with this potentially high maintenance item.

The off-gas recycled material evaporator system. This system concentrates the off-gas salts to about $30 \%$ total solids, producing a clean water discharge and a concentrate which is mixed with the concentrated low level waste. The clean water is discharged through zeolites to remove any cesium and strontium that has carried over from the evaporator. An option is to treat the off-gas liquid stream with zeolites first to remove any cesium or strontium which has been carried over from the plasma vitrification facility. The alternative approach may be attractive if cesium volatilization is unacceptably high. By first trapping the cesium in the zeolite and then melting the cesium loaded zeolite, it may be possible to reduce cesium volatility. 


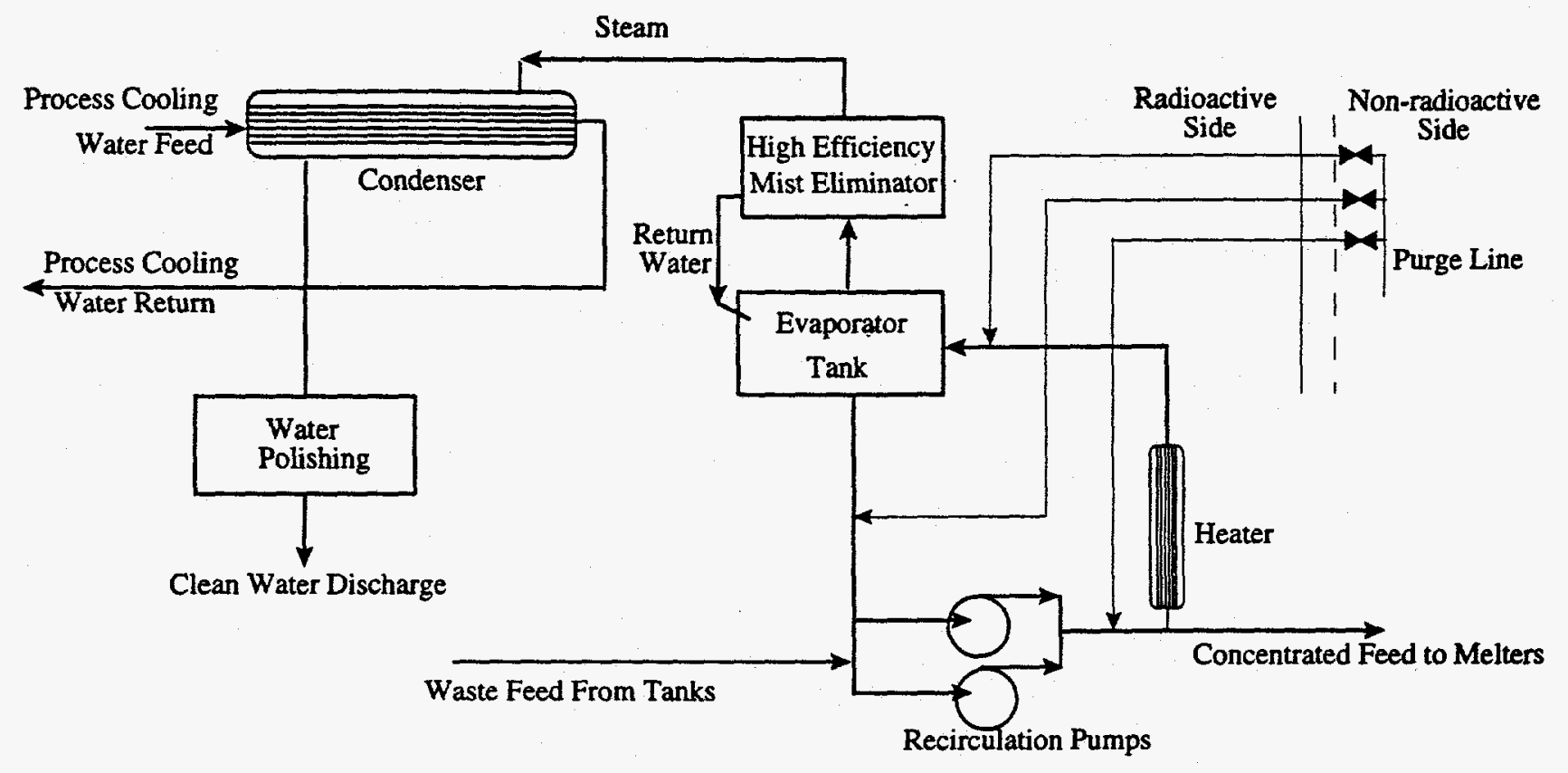

\section{Radioactive Feed and Off-Gas Liquids Evaporators}

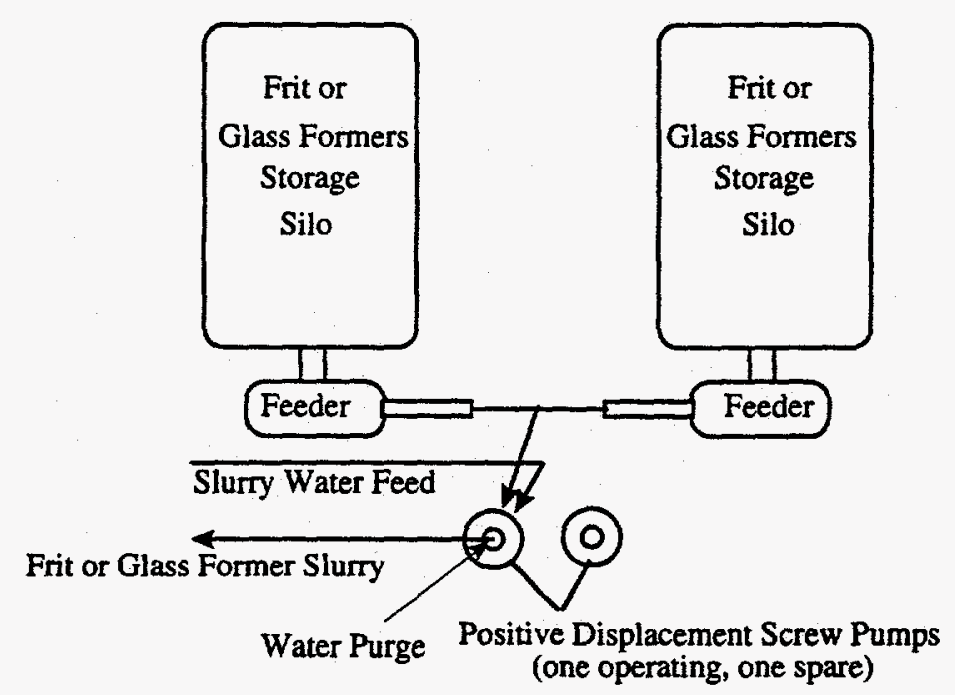

\section{Frit or Glass Former and High Sodium Frit Feed Systems}

Figure 4.5 - Waste and Frit Feed Systems Flowsheet 
1. Recycling the offgas material to the plasma vitrification process is not expected to present a problem.

Since the waste, frit and recycled off-gas materials are injected into the plasma stream and calcined (or combusted in the case of organics), and melted as a gas entrained stream, pretreatment of the waste to remove nitrates, nitrites, carbonates, water, or organics is not required. The degree of pre-evaporation is governed only by considerations of (1) maintaining steady-state concentrations of water in the system from steam condensation, and (2) minimizing capital investment in the vitrification and offgas facilities.

\subsection{OFF-GAS TREATMENT}

The off-as treatment process is shown in Figure 4.6. This process is the same that has been successfully demonstrated on a full scale basis at the Savannah River Defense Waste Processing Facility (DWPF) up through cold chemical runs. In this process, the offgas is first quenched just above the melter using a water spray to about $200^{\circ} \mathrm{C}$. The objective of this quench is to cool any entrained molten solids (halides, hydroxides, borates) to below their melting point to minimize sticking on the walls of the offgas ducts. Next, the gas temperature is lowered to about $80^{\circ} \mathrm{C}$ in a direct contact venturi condenser. This step removes most of the water vapor and up to $99.99 \%$ of the solids from the gas stream. The remaining gas is then sent through a countercurrent spray tower to coagulate and remove most of the small water droplets and any tars or entrained solids. The scrubbed gases are then sent through a demister, a reheater where the gas temperature is raised to about $110^{\circ} \mathrm{C}$, roughing and HEPA filtration, iodine removal (if required), a final sand filter, the blowers and then discharged to the stack. For extremely fine particle size or high particulate loading a second stage of scrubbing may be required.

As noted above, a sidestream of liquid is continuously withdrawn from the liquid cooling loop and sent to the zeolite removal columns and thence to the off-gas liquid evaporator. This liquid stream is concentrated to about $30 \%$ total solids. The evaporate is discharged through zeolite guard columns (and possibly additional effluent treatment processes such as reverse osmosis or ion exchange as required), and the concentrates are recycled to the Plasma Vitrification facility. The liquid quench stream is cooled by heat exchangers coupled to indirect cooling towers. This approach provides the barrier between the radioactive liquids and the non-radioactive coolant.

The use of air in the plasma torch results in the formation of about $2000 \mathrm{ppm}$ of $\mathrm{NO}_{x}$ in the outlet gas stream. Very little $\mathrm{NO}_{x}$ is formed from the calcination of the $\mathrm{NaNO}_{3}$. Four approaches have been considered to reduce the $\mathrm{NO}_{x}$ emission levels including:

- Injection of ammonia in the off-gas shaft,

- Use of catalytic $\mathrm{NO}_{x}$ destruction in the stack

- $\mathrm{CH}_{4}$ injection in torch with the torch air, and

- Substitution of another gas for air in the torch (i.e., oxygen or nitrogen) which cannot form $\mathrm{NO}_{\mathbf{x}}$ in the arc. 
The use of an alternative torch working gas such as oxygen or nitrogen is feasible, though probably more expensive than the use of ammonia. Catalytic $\mathrm{NO}_{\mathrm{x}}$ reduction in the stack will likely be effective though harder to control. This approach, however, is proven technology and would be easily implemented on the very clean, solids-free stack gas. Neither $\mathrm{CH}_{4}$ injection in the torch gas nor ammonia injection in the offgas shaft at temperatures between 950 and $1050^{\circ} \mathrm{C}$ are proven, though both are potentially easier to implement than catalytic reduction. 
ํㅗㅇ

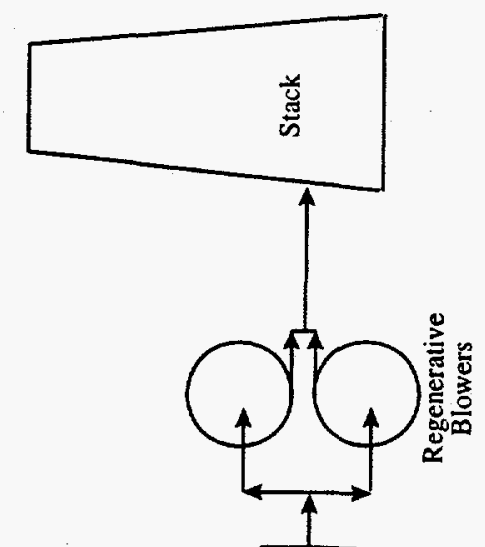



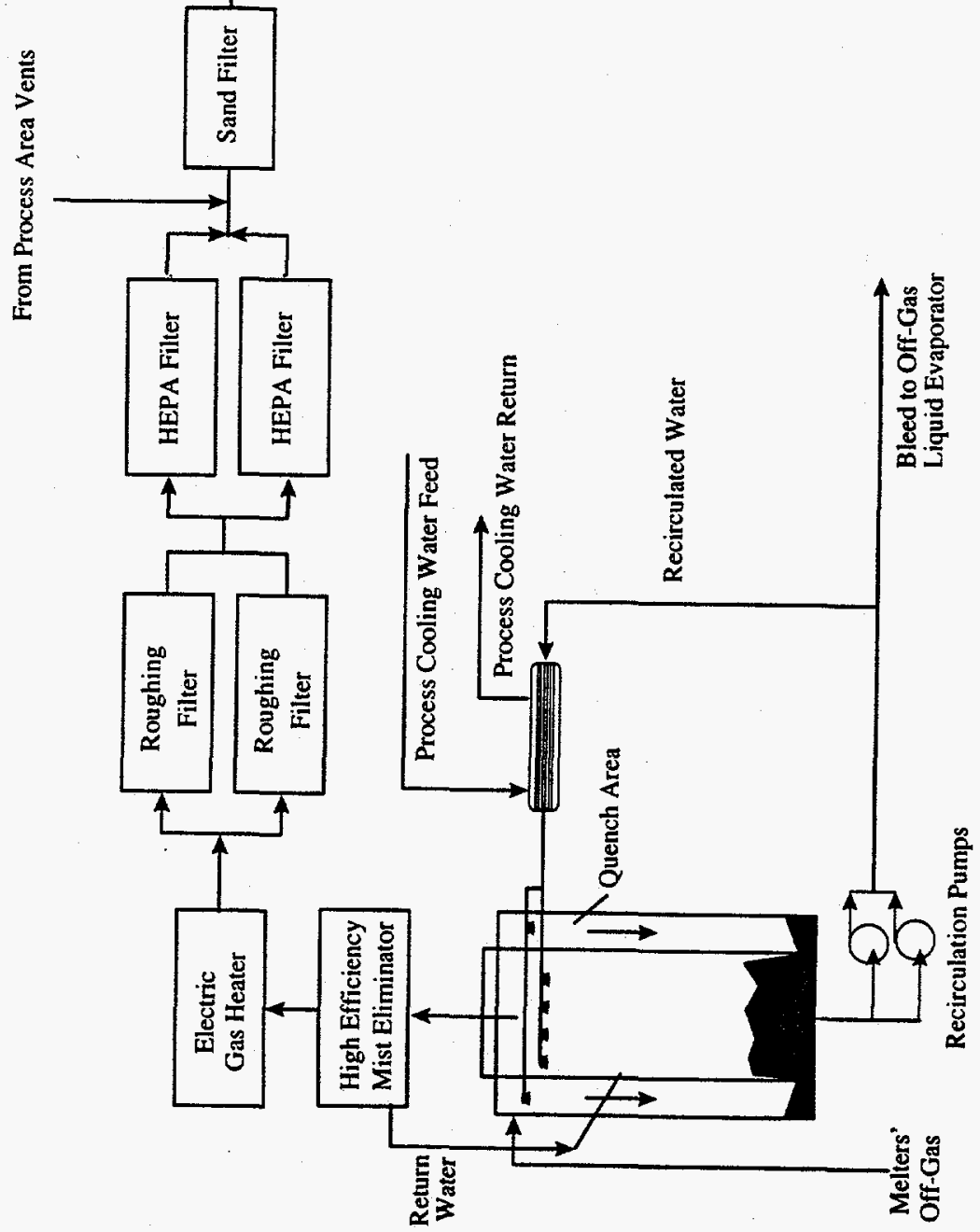

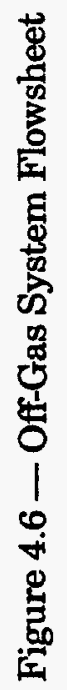




\section{TECHNOLOGY DEVELOPMENT STATUS}

The Westinghouse Plasma Vitrification process is a mature technology with largescale commercial applications in the melting of metals, and numerous large-scale pilot tests for vitrifying soils, simulated waste sludges, simulated high level waste, and simulated low level waste (see Section 5.3 below). The experience gained from processing these streams allows Westinghouse to efficiently use test experience to determine what process changes should be made to provide an optimum process. Based on the successful Phase I test program carried out at the Westinghouse Plasma Center at Waltz Mill, PA on simulated low level waste, the primary technical issue which must be addressed is the amount of volatility losses from the plasma melter. This issue and the proposed approaches is discussed is Section 5.1 below. Other design issues which should be addressed but which are more limited in scope are also discussed in Section 5.1. The behavior of the Westinghouse Plasma Vitrification Process using other waste feeds can also be evaluated based on our experience and the current test results (see Section 5.2 below).

\subsection{KEY TECHNICAL ISSUES FOR PHASE II RESOLUTION} include:

Technical issues which are proposed for study during Phase II demonstrations

1. Elimination of sodium borate losses and subsequent increase in alkali retention efficiency.

2. Elimination of progressive cavity pump wear in radioactive service.

3. Minimization of refractory wear and maintenance requirements.

4. Reduction in total offgas volumetric generation.

5. Abatement of nitrogen oxide production by the plasma arc.

6. Improved overall energy efficiency through improved tuyere design.

7. Increased capability to handle solids entrainment without offgas ductwork buildups.

8. Demonstration of minimal maintenance pour spout design.

9. Demonstration and characterization of waste vitrification with batch glassformer materials.

The issues which are covered here are suggested changes which resulted from issues identified during the Phase I testing (i.e., solids buildup in the offgas system). Although these difficulties were all overcome and the Phase I testing successfully completed, Westinghouse recognizes that process changes that eliminate the causes of these problems will result in a better performing, low maintenance process. Other changes which will be discussed below result from the Westinghouse process experience 
base, which is used to change the process so as to eliminate potential problems and reduce potential maintenance problems (i.e., the use of a slurry to move the frit or the glass former feeds to the radioactive area rather than putting the pump in the radioactive area). These changes have been incorporated into the current design since they are generally differences in engineering design rather than changes in the basic process chemistry. However, Westinghouse recommends demonstration of the efficacy of these changes in future test programs.

\subsubsection{Carryover of Alkali Metals into the Offgas System}

Perhaps the major technical issue identified as part of the Phase I testing using the Westinghouse Plasma Vitrification Process was volatility loss of alkali metals, primarily due to formation of volatile borate compounds. The sodium losses are of concern since (1) it is desirable to minimize the size of the required scrubber system recycle loop, and (2) previous testing has indicated that cesium behaves similarly to sodium but exhibits significantly greater volatility.

There are several approaches to eliminating this problem which can be tested in Phase II of this program. The first is to use a glass composition which greatly reduces or entirely eliminates boron. It is believed that glass compositions of good durability can be fabricated without boron; one of the five "pre-approved" Battelle Pacific Northwest Laboratories (PNL) compositions for Phase I testing (LD5-912) was a non-borosilicate glass." A number of compositions have been considered in a preliminary manner by WSTC and the Savannah River Technology Center (SRTC) for Phase II testing, including the following two current candidates:

\section{Table 5.1 - Preliminary Candidate Phase II Non-Borosilicate Glass Compositions}

\begin{tabular}{|c|c|c|}
\hline Species & Composition M2-3 & Composition H2-1 \\
\hline $\mathrm{SiO}_{2}$ & 54.4 & 44.4 \\
\hline $\mathrm{Na}_{2} \mathrm{O}$ & 18.4 & 18.2 \\
\hline $\mathrm{Al}_{2} \mathrm{O}_{3}$ & 12.4 & 17.9 \\
\hline $\mathrm{CaO}$ & 7.6 & 13.5 \\
\hline $\mathrm{ZrO}_{2}$ & 3.0 & 2.1 \\
\hline $\mathrm{Li}_{2} \mathrm{O}$ & 1.9 & 1.6 \\
\hline Other & 2.3 & 2.3 \\
\hline
\end{tabular}

Coupon melting tests have been carried out at SRTC on both compositions; both produce homogeneous glass of reasonably low viscosity at $1275^{\circ} \mathrm{C}$, which is approximately the temperature at which the Phase I testing was carried out. Preliminary alkali retention results for the coupon tests indicate $>\mathbf{9 7 \%}$ sodium

- D. S. Kim, "Candidate Melter Vendor Glasses," Pacific Northwest Laboratories, May 16, 1994 (See Appendix B). 
containment in the glass. These and other compositions will be examined in greater detail in Phase II, including durability test by the PCT metric.

One potential drawback to this approach is that because of the absence of boron, the glassformer composition will exhibit a significantly higher melting point than the borosilicate mixture used during Phase I. As a result, the premelting process to convert this glassformer mixture into frit will be more difficult. While it was possible to smelt the Phase I glassformer frit with a gas-air combustion smelter, production of frit from boron-free compositions will require, at a minimum, gas-oxygen combustion smelting, and could require electromelting. If the latter process is required, the energy cost for frit smelting increases significantly. As indicated above in Section 4.2, significant operability and product quality advantages derive from the use of frit; selection of frit versus batch will therefore require a close examination of the processing requirements to smelt frit from the final glassformer composition selected, the cost of producing this material, and an assessment of the additional capital and operating costs associated with batch feed to the waste melter.

Another approach is to allow a long frit or glass former/waste feed mix time to allow more pre-reaction. This would tend to chemically tie up more of the sodium, potassium, and cesium with the silica and alumina before exposing the mix to the high melt temperature, thus lowering the amount of alkali evaporation. This approach is desirable for use with either a frit or batch glassformer approach. The principal difficulty with this approach is the lack of predictability of the pre-mix time. Too long of a pre-mix time could result in coagulation and cementation of the waste/glass former or frit mixture, although Phase I bench testing suggested that the viscosity of a glassformer frit-simulant mixture increases to unacceptable levels over a period of several hours; design of a pre-mixing system therefore has significant latitude. A preliminary effort is proposed for Phase II to understand the reactions of waste with the glass forming matrix material. In addition, the impact of pre-mixing on glass product quality and alkali retention should also be studied.

A second approach to pre-binding the alkali is by addition of zeolites to the feed slurry mixture as an alternative glassformer species. In this approach, the waste feed is pretreated with zeolite to selectively absorb cesium, and the balance of the glassformer composition is modified to account for metals supplied by the zeolite composition $\left(\mathrm{Na}_{2} \mathrm{O} \bullet \mathrm{Al}_{2} \mathrm{O}_{3} \bullet 2 \mathrm{SiO}_{2} \bullet \mathrm{H}_{2} \mathrm{O}\right)$. The advantage is similar to pre-mixing of caustic and glassformer, in that the cesium in particular is incorporated in a reasonably fixed manner before the addition of heat. In addition, some of the alumina is removed from the balance of the glassformer, which may reduce its melting point and simplify smelting of glassformer frit. Disadvantages include the need to supply the radioactive waste as a slurry (whereas previously it was possible to avoid the use of a slurry pump in radioactive service) and the inclusion of additional sodium as part of the glassformer (lowering the total waste oxide loading in the glass product). Stability of the zeolite in highly alkaline conditions also needs to be demonstrated.

Reduction of the shroud gas volumetric flowrate is another factor in improving volatiles retention. Alkali may be lost both as volatiles and as entrained aerosols; reduction of the total gas flowrate in the tuyere will have a beneficial effect on reducing loss of both categories of carryover. As discussed in Section 4.1.2, it should be possible to 
significantly reduce the flowrate of shroud gas in the vitrification tuyere with no deleterious impact on the glassforming process. Testing of this concept is proposed for Phase II.

Finally, it was noted that the nozzle design used in Phase I to inject the frit/waste mixture into the plume of the torch was not optimized, although it was highly successful. The Phase II proposal will contain recommended modifications to the current nozzle design aimed at improved energy efficiency and increased throughput per tuyere.

Based on the above considerations, Westinghouse recommends Phase II testing of boron-free glassformer, characterization of glass allkali retention as a function of premixing time and zeolite addition, modification of the tuyere injection nozzle system, and reduction of shroud gas flow to determine the approaches of choice for improving volatiles retention.

\subsubsection{Feed Pump Wear}

The waste feed pump will have a significant wear rate due to the very abrasive nature of the glassformer (either as glass powder or batch chemicals), thus causing excessive maintenance if the pump is located in a radioactive area. The proposed approach to solving this problem is to inject the glass forming materials or frit into the radioactive areas of the process in the form of a slurry, blending the glassformers with the waste prior to injection into the tuyere. The main disadvantage of this approach is that additional water will be added to the process resulting in a reduction of the melting capacity for a given torch power. However, the use of a slurry feed of glassformers and the in-line mixing with the waste before injection into the torch plume will result in a significant decrease in the amount of maintenance which must be performed in a radioactive area.

Westinghouse therefore recommends the testing of the use of a slurry feed of glassformers and the in-line mixing with the waste before injection into the torch plume during future phases of this project.

\subsubsection{Refractory Wear}

High rates of refractory wear are expected due to the high temperatures and chemically corrosive conditions found throughout the process. The approach that is proposed to alleviate the maintenance concerns associated with refractory wear is to eliminate the use of the refractory (see Section 6.3). The alternative is to use a water cooled wall made out of a corrosion resistant material such as nickel or nickel alloy. The cold wall would then form a protective layer of solidified glass. The disadvantages of this approach are the marginally higher expected initial capital cost and the need for administrative controls to prevent turning on a torch without turning on the wall cooling. The higher initial capital cost would likely be recovered by the avoidance of refractory maintenance which would result in a higher on-line time.

An additional advantage of this approach are the elimination of refractory maintenance time and cost and in the increased ease of decontamination of the wall. 
Decontamination would be carried out by turning down the cooling water flow and allowing the contaminated glass coating to melt off, or by providing a non-radioactive liquid sodium salt feed for a period of time to dissolve and wash the existing glass skull coating.

Westinghouse proposes that the use of a water cooled wall be tested during future phases of this program. This test would consist of a double walled, water cooled tuyere. A test on the tuyere area is proposed since it has highest wear rate and potentially the highest corrosion rate due to the presence of uncombined, molten alkalis. Items to be tested include the controllability of the glass layer thickness, the corrosion and erosion of candidate materials (e.g., nickel or Incoloy-600), and demonstration of the decontamination of the wall.

\subsubsection{NO Reduction}

The use of air in the plasma torch results in the formation of about $2000 \mathrm{ppm}$ of $\mathrm{NO}_{z}$ in the outlet gas stream. Very little $\mathrm{NO}_{x}$ is formed from the calcination of the $\mathrm{NaNO}_{3}$. Four approaches have been considered to reduce the $\mathrm{NO}_{2}$ emission levels including:

- Injection of ammonia in the off-gas shaft,

- Use of catalytic $\mathrm{NO}_{\mathrm{x}}$ destruction in the stack

- $\mathrm{CH}_{4}$ injection in torch with the torch air, and

- Substitution of another gas for air in the torch (i.e., oxygen or nitrogen) which cannot form $\mathrm{NO}_{x}$ in the arc.

The use of an alternative torch working gas such as oxygen or nitrogen is feasible, though probably more expensive than the use of ammonia. Catalytic $\mathrm{NO}_{\mathrm{z}}$ reduction in the stack will likely be effective though harder to control. This approach, however, is proven technology and would be easily implemented on the very clean, solids-free stack gas. Neither $\mathrm{CH}_{4}$ injection in the torch gas nor ammonia injection in the offgas shaft at temperatures between 950 and $1050^{\circ} \mathrm{C}$ are proven, though both are potentially easier to implement than catalytic reduction.

Westinghouse recommends that based on the potential simplicity of the processes, both $\mathrm{CH}_{4}$ and ammonia injection be tested during future phases to determine the applicability and operating characteristics of both approaches.

\subsubsection{Tuyere Design and Orientation}

These changes are aimed at providing direct melt heating, reduced tuyere turbulence, and increased energy efficiency. The proper design and operation of the tuyere is a key requirement for efficient and maintenance-free operation of the Westinghouse Plasma Vitrification Process. The first change recommended in the design of the tuyere is the increase in its angle to about $30-45^{\circ}$ from a vertical position. This design change will accomplish the following:

1. Provide for direct heating of the crucible-resident glass melt which will decrease the time required for a cold melter startup (see Section 6.3); 
2. Decrease the carryover of suspended materials due to the direct impingement of the suspended solids on a hot, molten surface;

3. Allow free drainage of molten and semi-molten materials from the tuyere.

4. Reduce the erosion damage potential of the gas stream coming out of the tuyere on the wall of the crucible.

The second recommended design change is changing of the tuyere geometry to optimize energy utilization and minimize erosive/corrosive losses along the walls. Details of these proposed changes will be included in the Phase II proposal.

The final recommended design change is to lower or eliminate the shroud gas flow. In a traditional matter design where hot gas is the only fluid in the tuyere, the shroud gas flow is designed to protect the walls of the tuyere from direct impingement of the torch gas. In the case of the plasma torch melter, there is considerable induced turbulence due to evaporation of water and the calcination and melting of solids. This turbulence likely disrupts the shroud gas flow enough to make its effectiveness for its intended use problematical at best. Furthermore, the molten products and the cooled glass layer are probably sufficient to protect the walls of the tuyere. In addition, elimination of the shroud gas flow would result in about a $10 \%$ increase in torch melting capacity for the same applied power.

It should be noted that the tuyere design used in the plasma melter uses a tuyere bolted on to the melter body. This allows tuyeres to be replaced if required without losing a melter for an extended period of time. In addition, the inner shell of the tuyere can be a nickel casting which will eliminate the possibility of weld failures.

Westinghouse recommends that the tuyere design be modified to provide a steep angle, modification of the tuyere geometry, and the reduction or elimination of the shroud gas flow during future test phases.

\subsubsection{Avoidance of Solids Buildup in Offgas Ducts}

During the performance of the 26-hour Demonstration Test, a buildup of solids on the walls of the horizontal duct occurred. This buildup appeared to accelerate when the charge door near the top of the melter vertical shaft was closed, greatly reducing the ingestion of cold room air into the duct. The resulting buildup may have been due to the fact that the liquid droplets which were carried over from the melter remained molten long enough to adhere to the walls of the duct. Previously, these droplets were quenched by the cold air flow and were less adherent to the walls.

The buildup of offgas ductwork solids is directly related to volatiles carryover, which has been addressed in Section 5.1.1, and is expected to be greatly diminished by use of a non-borosilicate glass composition. Some volatilization is inevitable, however, owing to loss of halides and hydroxides, and consideration of equipment design to minimize the probability of accumulation is still appropriate. In order to minimize solids buildup on the walls while keeping total gas flow to a minimum, it is proposed that a water quench of the offgas be tested in the offgas shaft. The objective of this quench would be to rapidly reduce the solids temperature of the entrained liquid droplets to below their freezing point and thus prevent or minimize solids buildup. A water quench is preferred to injected gas cooling due to the higher heat absorbing capacity of water 
versus air; a lower total offgas volumetric flowrate therefore results from water quenching. In addition, the steam that is formed can be condensed out of the offgas, reducing the volume of flow to the downstream gas cleaning components.

Westinghouse therefore recommends that a water quench of the offgas be tested as part of future testing.

\subsubsection{Design of a Pour Spout with Minimal Maintenance Requirements}

The current Pilot Plant pour spout design of the plasma melter is aimed at minimizing heat losses and separating high and low density immiscible liquids (i.e., oxide slags from metal). This design, while perfectly serviceable in a non-radioactive, hands-on steel mill environment, is not suitable for a radioactive, remotely operated process. Therefore, the design and testing of an alternative pour spout is proposed as part of Phase II. A design concept that is proposed is shown in Figure 5.1. In this design, refractory lining is replaced with a water cooled double shell as in the case of the tuyere and crucible. Auxiliary heat is provided by Canthal glow bars operating at about $1650^{\circ} \mathrm{C}$. The flow is turned off directing a flow of cold gas at the outlet of the spout.

\subsection{POTENTIAL WASTE COMPOSITIONS}

The proposed non-DSSF simulant composition provided by Hanford as Table 3 of original RFP was reviewed to determine what, if any, potential effects would result from composition changes in the waste. Table 5.2 lists the components whose composition significantly ( $>10 \%$ ) changes from the Double-Shell Slurry Feed (DSSF) to the remaining inventory composition and the expected process ramifications. Note that the $\mathrm{K}_{2} \mathrm{O}+\mathrm{Na}_{2} \mathrm{O}$ components were considered as one component.

None of the composition changes described in Table 5.2 are expected to have a significant impact on the operation or product quality of the Plasma Vitrification unit. This is because the calcined waste makes up only $25 \%$ of the final product. which means that the overall effect of the above changes is divided by four. In addition, since the Plasma Melter has a high flow rate at most points and does not have a significant pool volume of glass with low velocity, small variations in density in second phase calcined products will not have significant operational effects. The vitrified second phase materials will likely be incorporated into the final glass product as small inclusions. Finally, since the electrical conductivity properties of the final glass product do not influence the operation of the Plasma Melter, the resulting oxidation/reduction products formed in the vitrification process will not be of any significant operational consequence.

The evaporative concentration of feed and recycle will need to contend with possible precipitation of solids, either as adherent scale in the evaporator or suspended solids. The simulant tested in the latter part of Phase I (Optima Batch \#3) contained a much higher loading of total suspended solids (TSS) than did the previous batch; the identity of this TSS material has not yet been determined from chemical analysis. The degree of feed concentration will therefore need to be adjusted to ensure the operability of the feed and evaporation systems. 


\section{Table 5.2 - Components with $>10 \%$ Change Between the Double-Shell Slurry Feed and the Remaining Inventory}

\begin{tabular}{|c|c|c|c|}
\hline COMPONENT & Pct. Change & Weight Pct. & Expected Process Impact \\
\hline $\mathrm{Al}_{2} \mathrm{O}_{3}$ & -75 & 3.84 & $\begin{array}{l}\text { Increase in Al content of frit required. Requires } \\
\text { either use of higher-temperature frit smelting process } \\
\text { or use of batch glassformer materials. }\end{array}$ \\
\hline $\mathrm{Cs}_{2} \mathrm{O}$ & +14 & 0.66 & $\begin{array}{l}\text { Potential increase in off-gas activity by } 14 \% \text {. No } \\
\text { significant impact if zeolites used to treat recycled } \\
\text { offgas materials. }\end{array}$ \\
\hline $\mathrm{MgO}$ & -100 & $\Rightarrow 0$ & No significant change due to very low levels in waste. \\
\hline $\mathrm{MnO}_{2}$ & +400 & 0.04 & No significant change due to very low levels in waste. \\
\hline $\mathrm{MoO}_{3}$ & +15 & 0.68 & No significant change due to very low levels in waste. \\
\hline SrO & +17 & 0.49 & $\begin{array}{l}\text { No significant increase in offgas levels since } \mathrm{Sr} \\
\text { carryover expected to be small. }\end{array}$ \\
\hline $\mathrm{P}_{2} \mathrm{O}_{5}$ & +400 & 3.68 & $\begin{array}{l}\text { No significant impact on melter due to small } \\
\text { inventory in melter and high mixing. May form } \\
\text { minute amounts of second phase inclusions in final } \\
\text { glass. }\end{array}$ \\
\hline $\mathrm{SO}_{3}$ & +17 & 1.43 & No significant change due to very low levels in waste \\
\hline $\mathrm{NaCl}$ & -90 & 0.25 & $\begin{array}{l}\text { Decrease in second phase formation in glass product } \\
\text { and sodium volatile losses. }\end{array}$ \\
\hline $\mathrm{NaI}$ & +16 & 0.71 & $\begin{array}{l}\text { Potential increase in offgas activity by } 16 \% \text {. No } \\
\text { significant impact if iodine removal system used to } \\
\text { treat offgases. }\end{array}$ \\
\hline $\mathrm{NO}_{3}^{-}$ & +119 & - & Small increase in energy use. \\
\hline $\mathrm{NO}_{2}^{-}$ & -72 & - & Slight decrease in energy use. \\
\hline $\mathrm{OH}$ & -29 & - & Slight decrease in energy use. \\
\hline $\mathrm{CO}_{3}^{-2}$ & -64 & - & Slight decrease in energy use. \\
\hline Organic C & -83 & - & Slight decrease in energy use. \\
\hline
\end{tabular}

Although second phase formation is not expected to present significant problems to the Plasma Melter, volatility of certain components will always present an issue in this system because of the gas flow. Loss of halides, cesium, and technetium are expected to present the greatest concern, halides because of their inherent high volatility and ability to form volatile compounds with other metals, and $\mathrm{Cs}$ and Tc because of the radioactivity associated with these species. It would be speculative at this point to 


\section{Front View}

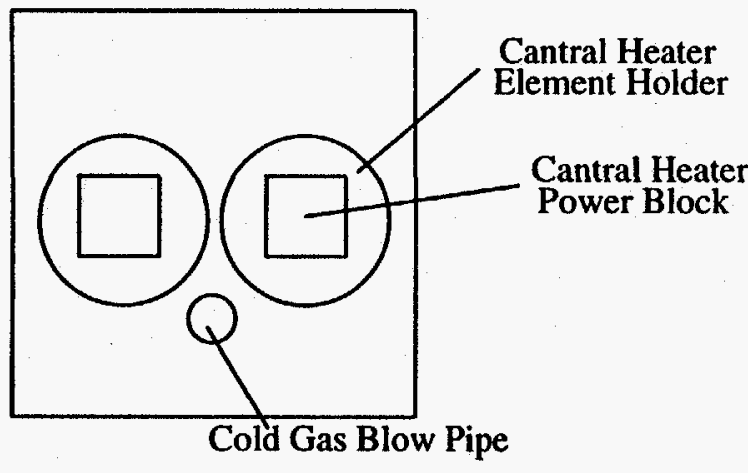

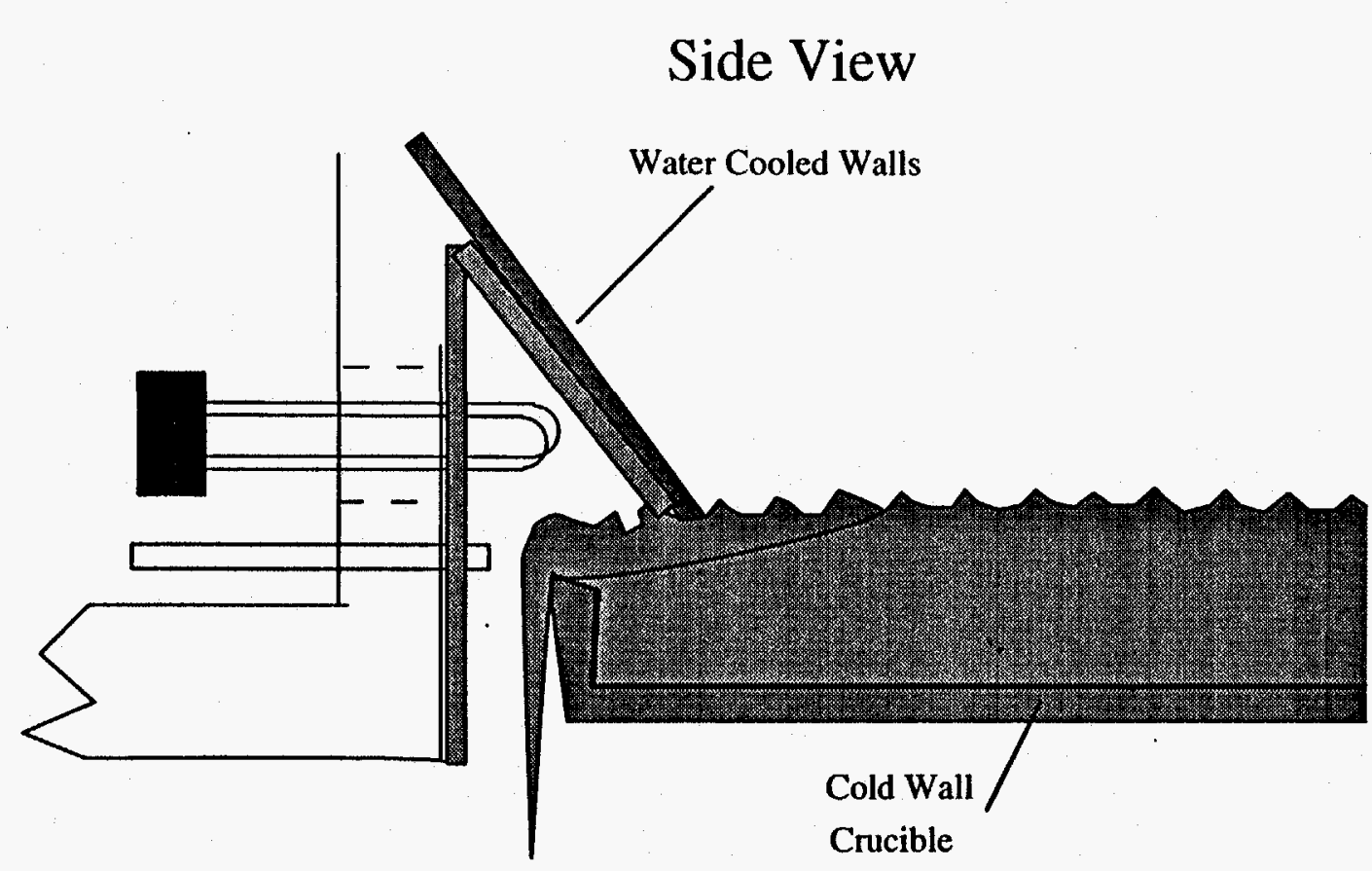

Figure 5.1 — Proposed Pour Spout Design 
discuss quantitative volatility loss for these species in the absence of (1) analytical data for Phase I testing with borosilicate glass or (2) any experimental data for nonborosilicate data.

\subsection{APPLICATION OF THE PLASMA MELTER AT HANFORD AS COMPARED TO PREVIOUS WESTINGHOUSE EXPERIENCE}

The Westinghouse Plasma Vitrification Process is a mature technology with numerous commercial applications in the melting of metals and a variety of large scale pilot tests for vitrifying soils, simulated waste sludges, simulated high level waste, and simulated low level waste. The applications which are relevant to the Hanford low-level waste vitrification project are shown in Table 5.3. The applications listed all were concerned with producing a molten product (either metal, glass, or calcine) which when solidified exhibited low solubility of hazardous metals such as $\mathrm{Cr}, \mathrm{Pb}$ and $\mathrm{Cd}$, and for which the melting process exhibited a minimal degree of vaporization or carryover of volatile components such as $\mathrm{Cs}, \mathrm{Pb}, \mathrm{Cd}, \mathrm{Zn}$ and $\mathrm{Hg}$. In all cases, testing was successfully completed.

The 1992-1993 tests with Hanford high level waste simulant provided a basis for the present testing. In the 1993 tests, a slurry/solution mixture containing in excess of 15 molar sodium salts was fed to the Plasma Melter. Injection of the waste slurry directly above the plasma plume in the tuyere resulted in rapid mixing of the waste and the superheated gases, evaporation of the water fraction, and calcination of the nitrates, nitrites, and organics.

One significant difference between the calcination and vitrification studies carried out for Westinghouse Hanford and other melting/vitrification studies has been the use of a coke bed. The studies of nitrate calcination for Fernald, waste disposal for PSI and Bloomington, and vitrification studies with $\mathrm{Al}$ dross and MSW were carried out in the presence of a coke bed. The chemistry of these tests was reducing, with the gas phase consisting largely of carbon monoxide. The coke bed through which the hot offgases passed is also believed to act as a filter, collecting aerosols and entrained molten particles, and gradually returning them to the crucible region as the coke is consumed by combustion. This mode of operation was initially considered for the second trial heat of Phase I, given concern about potentially high volatiles escape from the melter. Significant operational issues are also involved with this mode of operation, chief among them reforming of waste slurry water with hot coke to form $\mathrm{CO}$ and $\mathrm{H}_{2}$; although operated successfully by WSTC in a number of situations, reformer gas has the potential of creating an explosion situation. In addition, the large quantity of water being processed consumes relatively large quantities of coke. Ash constituents in the coke (including $\mathrm{SiO}_{2}$ and $\mathrm{Al}_{2} \mathrm{O}_{3}$ ) must also be accounted for as secondary glassformers, making control of the glass composition more complex. Given these issues and the success of the 
Table 5.3 - Plasma Vitrification and Melting Applications

\begin{tabular}{|c|c|c|c|c|c|}
\hline Customer & Application/Date & $\begin{array}{c}\text { Pilot } \\
\text { Scale } \\
\text { Testing }\end{array}$ & $\begin{array}{l}\text { Development } \\
\text { Engineering }\end{array}$ & $\begin{array}{c}\text { Field } \\
\text { Engineering }\end{array}$ & $\begin{array}{c}\text { Hardware } \\
\text { Supply }\end{array}$ \\
\hline Westinghouse/PSI & $\begin{array}{c}\text { Waste } \\
\text { Disposal/1984-86 }\end{array}$ & $x$ &.$^{x}$ & $x$ & $x$ \\
\hline Fernald & $\begin{array}{c}\mathrm{MgF}_{2} \\
\text { Oxidation/1987 }\end{array}$ & $x$ & $x$ & & \\
\hline Fernald & $\begin{array}{c}\mathrm{Ca}\left(\mathrm{NO}_{3}\right)_{2} \\
\text { Calcination/1988 }\end{array}$ & $x$ & $x$ & & \\
\hline $\begin{array}{l}\text { Westinghouse/ } \\
\text { Bloomington }\end{array}$ & $\begin{array}{c}\text { Vitrification of } \\
\text { Excavated Landfill } \\
\text { Material/1989 }\end{array}$ & $x$ & $x$ & & \\
\hline ALCAN/Canada & $\begin{array}{c}\text { Al Dross } \\
\text { Processing/1992 }\end{array}$ & $\bar{x}$ & $\bar{x}$ & $x$ & \\
\hline W. Hanford Co. & $\begin{array}{l}\text { HLW Simulated } \\
\text { Sludge Calcination } \\
\text { Phase V1992 }\end{array}$ & $\bar{x}$ & $x$ & & \\
\hline IHI/Japan & $\begin{array}{c}\text { MSW Ash } \\
\text { Vitrification/1993-94 }\end{array}$ & $x$ & $\bar{x}$ & $x$ & $x$ \\
\hline W. Hanford Co. & $\begin{array}{l}\text { HLW Simulated } \\
\text { Sludge Calcination } \\
\text { Phase II/1993 }\end{array}$ & $\bar{x}$ & $\bar{x}$ & & \\
\hline W. Hanford Co. & $\begin{array}{c}\text { LLW Simulated } \\
\text { Sludge Vitrification } \\
\text { Phase I/1994 }\end{array}$ & $x$ & & & \\
\hline
\end{tabular}

Phase I Trial Heat \#1 at retaining $85 \%$ of sodium in the glass, the decision was made not to include coke bed testing in Phase I. This approach still remains an option for future testing.

The balance of issues associated with adapting this technology to Hanford application are associated with ensuring that reliability and maintainability are consistent with remote radioactive operation, where any type of maintenance is likely to be very expensive. The relatively small size of the individual melter, limited inventory, and the opportunity to minimize refractory by cold skull technology should make maintenance of this melter design infrequent. The torches themselves are in minimal contact with the process materials, and can be readily maintained as discussed above. 
WHC-SD-WM-VI-015 Revision 0

THIS PAGE INTENTIONALLY LEFT BLANK 


\section{OPERATING PERFORMANCE CHARACTERISTICS}

This section will address operating performance characteristics of the Westinghouse Plasma Melter, including expected offgas production and temperatures, recycle of volatiles, melt properties compatible with the process, and service utility requirements.

\subsection{OFF-GAS VOLUME AND CHARACTERISTICS}

Offgas from the Plasma Melter derives from a variety of sources:

- Working gas supplied to the plasma arc.

- Shroud gas injected into the tuyere to promote mixing, reduce the plume temperature, and protect the tuyere refractory.

- Steam developed from evaporation of waste slurry water.

- Calcination gases $\left(\mathrm{N}_{2}, \mathrm{O}_{2}, \mathrm{CO}_{2}, \mathrm{NO}_{x}\right.$, and $\left.\mathrm{SO}_{\mathbf{x}}\right)$ developed from decomposition of nitrates, nitrites, carbonates, and organic species in the waste.

- Volatized salts from the calcined waste ( $\mathrm{NaCl}, \mathrm{NaI}, \mathrm{NaF}$, and $\mathrm{Na}_{2} \mathrm{SO}_{4}$ ).

- Calcination gases from decomposition of batch glassformers $\left(\mathrm{N}_{2}, \mathrm{O}_{2}, \mathrm{CO}_{2}, \mathrm{NO}_{\mathrm{x}}\right)$.

- Evaporation of volatile species from glassformers $\left(\mathrm{NaBO}_{2}\right)$.

Offgas generation rates typical of the Phase I Demonstration Test are shown in Table 6.1. Both the torch working gas and shroud flowrates were held at conservatively large values for this test. Note that simple throughput scaling with no improvement in offgas production would yield $515 \mathrm{std}-\mathrm{m}^{3} / \mathrm{min}$ of offgas $(18,200 \mathrm{scfm})$, of which approximately $80 \%$ is noncondensible. A number of approaches are available to reduce this figure, however. Typical torch working gas flowrates may be as low as 2.8 std$\mathrm{m}^{3} / \mathrm{min}(100 \mathrm{scfm})$ without jeopardizing torch operation, equivalent to a $7 \%$ reduction in total offgas. As discussed in Section 5.1.1, the large shroud gas flowrate (equivalent to $54 \%$ of the total melter offgas) could also be substantially reduced or even eliminated. The flow set for Phase I testing was based on historical operating data which was directed at maximizing the life expectancy of the tuyere refractory lining, with only air as the tuyere gas. In the case where the tuyere is being operated as a vitrification reactor, the opportunity exists to develop a self-healing skull coat in place of much or all of the refractory lining; in this case the large shroud gas flow serves little purpose but to reduce energy efficiency and increase offgas volume. The material balances shown in Section 4.1.2 assume shroud flow elimination. 
Table 6.1 - Characteristic Offgas from Phase I Plasma Melter Operation

\begin{tabular}{|l|l|}
\hline Offgas Source & Characteristic \\
\hline Basis Flowrate: & One torch/tuyere at $1532 \mathrm{kWe}$ \\
\hline & 3.8 liters $/ \mathrm{min}(1.0 \mathrm{gpm})$ DSSF simulant at $10 \mathrm{M} \mathrm{Na}$ \\
\hline & 7.1 tonnes/day glass production \\
\hline Plasma Torch Working Gas: & $4.2 \mathrm{std}-\mathrm{m}^{3} / \mathrm{min}(150 \mathrm{scfm})$ air \\
\hline Tuyere Shroud Gas: & $9.9 \mathrm{std}-\mathrm{m}^{3} / \mathrm{min}(350 \mathrm{scfm})$ air \\
\hline Waste Steam Generation: & $3.5 \mathrm{std}-\mathrm{m}^{3} / \mathrm{min}(125 \mathrm{scfm}) \mathrm{steam}$ \\
\hline Calcination Gases: & $0.7 \mathrm{std}-\mathrm{m}^{3} / \mathrm{min}(25 \mathrm{scfm}) \mathrm{N}_{2} / \mathrm{O}_{2} / \mathrm{CO}_{2} / \mathrm{steam}$ \\
\hline Total Melter Offgases: & $18.3 \mathrm{std}-\mathrm{m}^{3} / \mathrm{min}(650 \mathrm{scfm})$ \\
\hline Offgas Exit Temperature: & $1250^{\circ} \mathrm{C}$ \\
\hline
\end{tabular}

The offgases of concern are principally the noncondensible species, since steam can be effectively removed from the offgas by scrubbing and condensation. However, steam makes up a substantial fraction (19\%) of the melter offgas, and contributes to both the velocity and the stripping action which promote aerosolization, volatilization, and entrainment. Reduction of offgas steam requires concentration of the waste to a higher solids loading. Calcination testing in 1992 and 1993 with the Plasma Melter successfully processed simulated high-level waste at $15 \mathrm{M} \mathrm{Na}$ content, so that vitrification of more concentrated feed poses no problem. Evaporation of the feed to this concentration is likely to be difficult, however, due to scaling and solids precipitation.

Since steam is of less concern than noncondensible gases to the design of the offgas cleaning process, an alternative approach to reduction of noncondensible flow can be accomplished by substitution of steam for air as the shroud gas. This approach was suggested during the calcination program, and is equally valid here. The same benefits now provided by air shroud injection could be achieved with steam injection (if use of shroud flow is deemed to be necessary for mixing and heat transfer). Although this procedure has not been demonstrated experimentally, the only drawbacks to shroud steam injection are the greater complexity in generating the steam at high flowrate, the higher heat capacity (which would lower the tuyere mixing temperature for a given torch input power), and the higher offgas velocity (as compared to zero shroud flow) leading to greater volatiles carryover.

Note that during Phase I operation, gases leaving the melter vertical shaft were mixed with additional ingested air entering through the charge door at the top of the shaft. The presence of this partially open door is specific to the pilot plant design, and would not be present in a radioactive melter design, for obvious reasons. During Phase I test operations, therefore, the hot melter offgases were mixed with about $150 \%$ dilution air before scrubbing. As indicated in Section 5.1.6, this initial cooling lowered the temperature of some vapor-phase salts and precipitated them in the ductwork as liquids and solids. In that same section, use of a water spray quench is recommended to accomplish this same quenching. Water quenching has several advantages over air quenching: 
- A lower temperature is achieved where liquid phase condensation (and therefore accumulation) is avoided;

- Water washing of potential condensation surfaces also serves to minimize accumulation; and

- No addition noncondensible offgas is introduced.

Water quenching is employed in the offgas handling system for the DWPF high-level melter at Savannah River.

While the various volatile salts of species such as $\mathrm{Na}, \mathrm{K}, \mathrm{Ag}, \mathrm{As}, \mathrm{Be}, \mathrm{Bi}, \mathrm{Cd}, \mathrm{Co}$, $\mathrm{Cr}, \mathrm{Cu}, \mathrm{Hg}, \mathrm{Pb}, \mathrm{Ru}, \mathrm{Sb}, \mathrm{Se}, \mathrm{Sn}, \mathrm{Tc}, \mathrm{Tl}, \mathrm{V}$, and $\mathrm{Zn}$ add little to the total offgas volume, these species obviously are very important to melter operability due to possible deposition, their toxicity, and the radioactive nature of several of the salts (especially cesium, iodine, and technetium). Until the analytical results from Phase I become available, it is not possible to quantitatively assess carryover of volatiles; Phase $I$ analytical results will provide quantitative data on retention efficiency for $\mathrm{F}, \mathrm{Cl}, \mathrm{I}, \mathrm{P}, \mathrm{S}$, $\mathrm{Na}, \mathrm{K}, \mathrm{Cs}, \mathrm{Mo}$, and $\mathrm{Cr}$.

In the absence of data, thermodynamic modeling were carried out in 1993 on calcination of various Hanford tank waste compositions." Although the presence of glassformers will significantly reduce the formation of many volatile salts (as hydroxides) and bind others by mutual solubility in the oxide matrix (such as $\mathrm{PbO}, \mathrm{BiO}$, and $\mathrm{UO}_{3}$ ), examination of the high-temperature equilibrium production of volatile salts provides a worst-case equilibrium scenario and an understanding of the chemical speciation of the volatiles expected during Plasma Vitrification. Table 6.2 presents the predicted fractional volatility of a variety of waste elements at an assumed crucible temperature of $1250^{\circ} \mathrm{C}$. Conditions modeled represent composite Hanford waste ${ }^{\dagger}$ calcined at conditions very similar to Phase I vitrification, other than the presence of glassformers: $3.8 \mathrm{~L} / \mathrm{min}$ of waste at $15 \mathrm{M} \mathrm{Na}$ concentration, processed with $12.7 \mathrm{std}$ $\mathrm{m} / \mathrm{min}(450 \mathrm{scfm})$ of torch and shroud air.

- D. F. McLaughlin and S. H. Peterson, Thermodynamic Simulation of Oxidative Plasma Calcination of Five Hanford High-Level Tank Waste Compositions," Appendix B of C. H. Delegard, F. F. Creed, D. W. Hendrickson, and D. F. McLaughlin, "Calcination/Dissolution Process Development 1994, Westinghouse Hanford WHC-SP-1093 Rev. 0, June 1994.

${ }^{\dagger}$ C. H. Delegard, T. D. Elcan, and B. E. Hey, "Chemistry of Application of Calcination/Dissolution to the Hanford Tank Waste Inventory," Appendix E of C. H. Delegard, F. F. Creed, D. W. Hendrickson, and D. F. McLaughlin, "Calcination/Dissolution Process Development 1994, Westinghouse Hanford WHC-SP-1093 Rev. 0, June 1994. 
Table 6.2 - Thermodynamic Predictions of Hanford Tank Waste Species Volatilities at $1250^{\circ} \mathrm{C}$

\begin{tabular}{|c|c|c|}
\hline Element & Fractional Volatility & Volatile Compounds \\
\hline $\mathrm{Ag}$ & $100 \%$ & $\mathrm{Ag}(100 \%)$ \\
\hline $\mathrm{Al}$ & $0 \%$ & - \\
\hline As & $100 \%$ & AsO $(100 \%)$ \\
\hline B & $100 \%$ & $\mathrm{NaBO}_{2}(99 \%), \mathrm{KBO}_{2}(1 \%)$ \\
\hline $\mathrm{Ba}$ & $2 \%$ & $\mathrm{Ba}\left(\mathrm{OH}_{2}(2 \%)\right.$ \\
\hline$\overline{\mathrm{Bi}}$ & $100 \%$ & $\mathrm{BiO}(78 \%), \mathrm{Bi}(22 \%)$ \\
\hline$\overline{\mathrm{Ca}}$ & $0 \%$ & - \\
\hline $\mathrm{Cd}$ & $100 \%$ & $\mathrm{CdO}(88 \%), \mathrm{Cd}(12 \%)$ \\
\hline $\mathrm{Ce}$ & $0 \%$ & - \\
\hline $\mathrm{Cl}$ & $100 \%$ & $\mathrm{NaCl}(99 \%), \mathrm{KCl}(1 \%)$ \\
\hline $\mathrm{Co}$ & $0 \%$ & - \\
\hline $\mathrm{Cr}$ & $0 \%$ & - \\
\hline Cs & $100 \%$ & $\mathrm{CsOH}(97 \%), \mathrm{CsF}(2 \%), \mathrm{CsCl}(1 \%)$ \\
\hline$\overline{\mathrm{Cu}}$ & $100 \%$ & $\mathrm{Cu}(87 \%), \mathrm{CuO}(7 \%), \mathrm{CuF}(4 \%), \mathrm{CuCl}(1 \%)$ \\
\hline$F$ & $100 \%$ & $\mathrm{NaF}(90 \%), \mathrm{Na}_{2} \mathrm{~F}_{2}(8 \%), \mathrm{HF}(2 \%), \mathrm{KF}(1 \%)$ \\
\hline $\mathrm{Fe}$ & $0 \%$ & - \\
\hline $\mathrm{Hg}$ & $100 \%$ & $\mathrm{Hg}(98 \%), \mathrm{HgO}(2 \%)$ \\
\hline $\mathbf{K}$ & $100 \%$ & $\mathrm{KOH}(96 \%), \quad \mathrm{KF}(3 \%), \quad \mathrm{KCl}(1 \%)$ \\
\hline $\mathrm{La}$ & $0 \%$ & - \\
\hline $\mathrm{Mg}$ & $0 \%$ & - \\
\hline $\mathrm{Mn}$ & $0 \%$ & - \\
\hline Mo & $100 \%$ & $\mathrm{H}_{2} \mathrm{MoO}_{4}(100 \%)$ \\
\hline $\mathrm{Na}$ & $94 \%$ & $\mathrm{NaOH}(89 \%), \mathrm{Na}_{2}\left(\mathrm{OH}_{2}(2 \%), \mathrm{NaF}(2 \%), \mathrm{NaCl}(1 \%)\right.$ \\
\hline $\mathrm{Ni}$ & $1 \%$ & $\mathrm{Ni}(\mathrm{OH})_{2}(1 \%)$ \\
\hline $\mathbf{P}$ & $0 \%$ & - \\
\hline $\mathrm{Pb}$ & $100 \%$ & $\mathrm{PbO}(99 \%), \mathrm{Pb}(1 \%)$ \\
\hline$\overline{\mathbf{R h}}$ & $0 \%$ & - \\
\hline Ru & $100 \%$ & $\mathrm{RuO}(99 \%), \mathrm{RuO}_{3}(1 \%)$ \\
\hline$S$ & $22 \%$ & $\mathrm{Na}_{2} \mathrm{SO}_{4}(22 \%)$ \\
\hline $\mathrm{Sr}$ & $0 \%$ & - \\
\hline Th & $0 \%$ & - \\
\hline $\mathrm{Ti}$ & $0 \%$ & - \\
\hline $\mathrm{U}$ & $100 \%$ & $\mathrm{UO}_{3}(100 \%)$ \\
\hline $\bar{W}$ & $0 \%$ & - \\
\hline$\overline{\mathbf{Z n}}$ & $100 \%$ & $\mathrm{ZnO}(99 \%), \mathrm{Zn}(1 \%)$ \\
\hline$\overline{\mathrm{Zr}}$ & $0 \%$ & - \\
\hline
\end{tabular}

Fluoride and chloride are seen to be $100 \%$ volatile at equilibrium at $1250^{\circ} \mathrm{C}$, resulting in approximately $3-4 \%$ volatilization of $\mathrm{Cs}, \mathrm{K}$, and $\mathrm{Na}$ as halides. Cesium is predicted to be $100 \%$ volatile, with hydroxide being the primary vehicle; it is not known without additional simulations to what extent the presence of glassformers would suppress formation of hydroxides. Phase I trial heat data indicate that alkali loss in the 
form of borate will dominate the results of the demonstration test; this behavior is substantiated by thermodynamic modeling, in which $100 \%$ loss of boron as $(\mathrm{Na}, \mathrm{K}) \mathrm{BO}_{2}$ is predicted in the absence of other glassformers. Note that once boron is eliminated from the glassformer mixture, loss of roughly $4 \%$ of sodium and potassium as halides is still expected, with some hydroxide carryover likely. Chromium is not expected to exhibit significant volatility under Phase I conditions; loss of at least some molybdenum as molybdic acid is anticipated.

\subsection{WASTE TREATMENT AND RECYCLE}

Given the anticipated volatility loss of at least $3-4 \%$ of the calcined solids as halides (which have very limited glass solubility) and additional losses as incompletely retained hydroxides, collection and recycle are mandatory. This process is straightforward in the Plasma Vitrification process, since no feed pretreatment is required. The scrubber liquor accumulates the volatile species. A bleed stream is withdrawn continuously, evaporated to the extent required to maintain steady-state water content in the recirculation system, and then the concentrate is reinjected into the tuyere in addition to the fresh waste. The resulting tuyere feed stream is therefore richer is sodium (for example) than the incoming feed, such that the process-defined retention fraction (perhaps $90 \%$ ) of the enriched sodium feed is equal to the total sodium entering as fresh waste.

The three trial heats carried out during Phase I were all run at simulant-toglassformer ratios richer than the theoretical ratio required to achieve $25 \%$ waste loading. Table 6.3 presents approximate fractional sodium retention data for the three trial heats, as measured by X-ray fluorescence (XRF) analysis of glass samples. The first two heats were conducted at $26 \%$ and $27 \%$ theoretical waste loading (zero volatility loss), while the third was inadvertently carried out at a much higher loading of $35 \%$ due a calibration error in the glassformer feed rate. The table indicates a functional dependence (albeit nonlinear) between fractional retention and attempted waste loading. At higher loading the ultimate soda content of the glass does increase, but the fraction retention decreases and performance as well. Approximately $85 \% \mathrm{Na}$ retention was achieved at $26 \%$ attempted loading, while retention dropped to $79 \%$ at $35 \%$ loading. (The fractional retention at 35\% attempted loading may be even lower than this; single sample values as low as $72 \%$ were observed, although the average was $79 \%$ ). 
Table 6.3 - Soda Retention and Leachability for Phase I Test Operations

\begin{tabular}{|c|c|c|c|c|}
\hline Run & Trial Heat \#1 & Trial Heat \#2 & Trial Heat \#3 & Demonstration Test \\
\hline Target Waste Loading (wt.pct.) & 25.9 & 27.2 & 28.0 & 28.8 \\
\hline $\begin{array}{l}\text { Measure Waste Loading } \\
\text { (wt.pct.) }\end{array}$ & 27.5 & 28.3 & $35 \%$ & $\mathrm{n} / \mathrm{a}$ \\
\hline $\begin{array}{c}\text { Measured Glass } \mathrm{Na}_{2} \mathrm{O} \text { Content } \\
\text { (wt.pct.) }\end{array}$ & 16 & 19 & 21 & $\mathbf{n} / \mathbf{a}$ \\
\hline Na Retention in Glass (\%) & 85 & 81 & 79 & $\mathrm{n} / \mathbf{a}$ \\
\hline $\begin{array}{c}\text { Glass Durability (Na leaching } \\
\text { vs. EA })^{(\mathrm{a})}\end{array}$ & 0.018 & $\bar{n} / \mathbf{a}$ & 0.061 & $n / a$ \\
\hline
\end{tabular}

(a) Normalized PCT Na leaching (gm/L) relative to value for Environmental Assessment glass.

In the case of Trial Heat \#1 for which chemical analyses were carried out of both the glass and scrubber liquor, essentially all of the sodium reported to the scrubber solution, and would have been readily available for collection and recycle. Data for the 26-hour Demonstration Test are not yet available. Phase I volatile carryover was largely in the form of $\mathrm{NaBO}_{2}$, as discussed above, so that overall alkali volatility loss is expected to be significantly reduced when a non-borosilicate glass composition is employed.

\subsection{ACCEPTABLE MELT PROPERTIES}

The hot vitrified glass melt properties must conform to a set of requirements as listed in Table 6.4 such that the glass can be manufactured and removed from the Westinghouse Plasma Melter, without excessive loss due to volatility. For purposes of this document, an upper limit of $15 \%$ volatiles recycle is set based on performance of the Phase I testing and a preliminary material balance on the volatiles recycle process. It is expected that Phase II demonstration testing with non-borosilicate glass compositions will exhibit substantially better volatiles retention in the glass product.

Table 6.4 - Melt Property Specifications

\begin{tabular}{|c|c|}
\hline Melt Property & Value \\
\hline Required Temperature & 1150 to $1450^{\circ} \mathrm{C}$ \\
\hline Minimum viscosity & 20 to 200 poise \\
\hline Volatility Retention & $>85 \%$ \\
\hline
\end{tabular}

Note that because the vitrification process occurs in the plasma tuyere rather than in the crucible, the melter operation is not sensitive to melt properties as long as the 
viscosity is sufficiently low to permit extraction, and the temperature low enough to prevent excessive volatility losses. Even crucible volatility losses are not expected to be strongly temperature dependent, since the residence time in the crucible is very short compared to large batch melters (only 30 to 60 minutes). Electrical conductivity is of no consequence, nor is oxidation-reduction state, unless very large quantities of iron were present such that the relative contribution to overall viscosity of $\mathrm{FeO}$ versus $\mathrm{Fe}_{2} \mathrm{O}_{3}$ became significant. The melt viscosity will, of course, be dependent on glass chemistry.

Melt opacity impacts the ability to restart the system if a glass inventory exists in the crucible which has frozen, since much of the heating by the plasma plume may be radiative. Inclining the tuyeres at a steeper angle (see discussion in Section 5.1.5) will allow direct impingement of the plasma plume on the melt pool, minimizing sensitivity to melt opacity. A more opaque melt is beneficial to developing a good skull coating within the tuyere and crucible if this approach is taken. A relatively transparent glass will permit deeper penetration of infrared, heating the glass closer to the wall surface, and making the temperature gradient which forms the skull coating more shallow. Under these conditions, a thinner coating will result, and heat losses to the wall will be greater. It is suggested that if a skull coating approach is taken, the glassformer mixture should be "spiked" with a small amount of iron (0.5 to 1.0\%) to increase opacity.

\subsection{MELTER SYSTEM UTILITIES AND SERVICES}

The utility and service requirements for the Plasma Melter include glassformers; process gas for the torch and tuyere shroud (air, $\mathrm{N}_{2}, \mathrm{O}_{2}$, steam); cooling water for the torch, tuyere, crucible, shaft, and evaporators; and electrical power to the torches, evaporators (assumed to operate with electric power), and pumps. Auxiliary feeds include $\mathrm{NO}_{x}$ abatement additives $\left(\mathrm{CH}_{4}\right.$ or $\left.\mathrm{NH}_{3}\right)$, "spike" iron oxide to increase melt opacity, and clean sodium feed for melting out skull coatings and decontamination of the system.

Scrap and re-work glass will be wet ball milled into a $25 \%$ by weight slurry with a maximum particle size of about 100 mesh. This slurry will then be pumped into the melter through a tuyere port in place of the normal feed and frit slurry.

\subsubsection{Utilities}

Utility requirements for operation of the Plasma Melter including electricity, process gases, cooling water are summarized in Table 6.5. These data are taken from the overall material and energy balance (see Table 4.3), assuming the design discussed in Section 4.1.2 (30 torches operating at $1870 \mathrm{kWe}, 85 \%$ electrical-to-thermal efficiency, $4 \mathrm{std}-\mathrm{m}^{3} / \mathrm{min}$ air to the torch and zero shroud gas flow, non-borosilicate frit glassformer with 95\% assumed retention efficiency). Note that in Section 5.1.4 several techniques were discussed for abatement of $\mathrm{NO}_{\mathrm{x}}$ generated by the plasma arc, including use of nitrogen, oxygen, or another gas in place of air. If this approach is taken, the nominal working gas flowrate would stay the same, simply substituting $\mathrm{N}_{2}$ or $\mathrm{O}_{2}$ for air.

Section 6.1 also suggested substitution of steam for air as the shroud gas to eliminate noncondensible offgas volume. Use of this approach would add steam to the 
utilities requirement, at some flowrate between zero and $7 \mathrm{std}-\mathrm{m}^{3} / \mathrm{min}$ per tuyere. Table 6.3 provides details of the functional requirements for the air and cooling water service to the Plasma Torch systems.

Table 6.5 - Utility Requirements for 200 Tonne/day Plasma Vitrification Facility

\begin{tabular}{|c|l|c|}
\hline \multicolumn{2}{|l|}{ Electrical Power } & $53,940 \mathrm{kWe}$ total \\
\hline & Plasma Torches & $53,270 \mathrm{kWe}$ \\
\hline & Glassformer Pumps & $60 \mathrm{kWe}$ \\
\hline & Offgas Recycle Evaporator & $30 \mathrm{kWe}$ \\
\hline & Waste Feed Evaporator & $100 \mathrm{kWe}$ \\
\hline & Offgas Processing System & $480 \mathrm{kWe}$ \\
\hline Cooling Water & $40,900 \mathrm{~kg} / \mathrm{min}$ total \\
\hline & Plasma Torches & $5,740 \mathrm{~kg} / \mathrm{min}$ \\
\hline & Plasma Melter System & $3,990 \mathrm{~kg} / \mathrm{min}$ \\
\hline & Offgas Recycle Evaporator & $980 \mathrm{~kg} / \mathrm{min}$ \\
\hline & Waste Feed Evaporator & $3,890 \mathrm{~kg} / \mathrm{min}$ \\
\hline & Offgas Processing System & $26,300 \mathrm{~kg} / \mathrm{min}$ \\
\hline Process Air & $112 \mathrm{std}-\mathrm{m}^{3} / \mathrm{min}$ total \\
\hline & Plasma Torch & $112 \mathrm{std}-\mathrm{m}^{3} / \mathrm{min}$ \\
\hline & Tuyere Shroud & $0 \mathrm{std}-\mathrm{m}^{3} / \mathrm{min}$ \\
\hline
\end{tabular}

Table 6.6 - Cooling Water and Process Air Specifications for Plasma Torch System

\begin{tabular}{|c|c|c|}
\hline \multicolumn{3}{|c|}{ Deionized Closed-Loop Cooling Water System } \\
\hline & System Pressure & 350 to $400 \mathrm{psig}$ \\
\hline & Torch Inlet Temperature & 21 to $38^{\circ} \mathrm{C}$ maximum \\
\hline & Torch Outlet Temperature & 29 to $32^{\circ} \mathrm{C}$ \\
\hline & Water Resistivity & $100,000 \Omega / \mathrm{cm}$ at $25^{\circ} \mathrm{C}$ minimum \\
\hline & Nitrogen Cover Gas System & 2 psig $N_{2}$ \\
\hline \multicolumn{3}{|c|}{ Plasma Torch Instrument Air System (Oil Free) } \\
\hline & System Pressure & 100 psig \\
\hline & Output Air Temperature & $64^{\circ} \mathrm{C}$ maximum \\
\hline & Dewpoint & -28 to $-51^{\circ} \mathrm{C}$ at 100 psig \\
\hline & Particulate Filtration & $99.97 \%$ efficient at 0.3 to $1.0 \mu \mathrm{m}$ \\
\hline
\end{tabular}

Electrical power to the Plasma Torch systems is delivered by a specially designed thyristor power supply, providing a current-controlled D.C. output. Depending on input voltage, the thyristor power supply typically includes a high voltage breaker or contactor for independent control and protection. A manually operated isolating switch is 
associated with the device for personnel protection during maintenance. A water-cooled transformer is typically used, with the secondary of the transformer connected to the thyristor bridges. Several different types of D.C. bridge configurations are commercially available from Westinghouse, depending of the customer and site requirements. Bridges are supplied either air or water cooled.

The output of the thyristor bridge is connected to a series iron-core inductor (smoothing reactor), providing the system with impedance for arc stability. The Plasma Torch is connected to the load side of the inductor through a switch which provides a visible break for maintenance safety. The entire system is highly optimized and modular for ease of maintenance and operability. Typical output voltage delivered to the torch is 900 to 1000 volts, with a delivered current of 2000 to 2200 amperes D.C. per torch.

\subsubsection{Feeds}

The only feeds to the glass process itself are (1) the waste slurry at approximately 6-7 $\mathrm{M}$ sodium and (2) the glassformer material, the composition of which is discussed above in Section 5.1.1. At an assumed 25\% loading of waste oxides into the glass, the glassformer feed rate becomes 150 tonnes/day, assuming premelted frit feed. If batch feed is used rather than frit, the mass flowrate of glassformer is increased somewhat, to the greater molecular weight of $\mathrm{Li}_{2} \mathrm{CO}_{3}$ (for example) than $\mathrm{Li}_{2} \mathrm{O}$ as a lithium source. Quantification of the exact mass flowrate requires specification of the particular glass composition, which will determined in Phase II testing. Because no feed pretreatment is required or recommended for the Plasma Vitrification process other than waste feed concentration through evaporation of excess water, no additional chemicals are required.

Several other chemical additions may be employed to support some of the process options discussed in Section 5.2. If a cold skull tuyere and/or crucible design is used, and the waste glass is quite transparent, it may be beneficial to add iron to the glassformer mixture at a concentration of perhaps $0.5 \%$ to raise the opacity of the glass and increase the steady-state thickness of the skull coat. Non-radioactive sodium feed (perhaps as a $\mathrm{NaOH}$ solution) may also be used in replacing the radioactive skull coating for purposes of decontamination prior to maintenance operations. The quantity of such strip feed must be determined experimentally using a system designed for cold skull operation; the initial skull might intentionally be doped with a high concentration of non-radioactive cesium, and the cesium concentration of glass product being removed from the melter monitored as a function of time to establish the decontamination rate. The cost of such feed will be small in any case, and only required as part of a maintenance procedure; the largest cost associated with this process will be disposal of the strip glass product which contains little radioactive waste.

The final chemical feeds which may be used in the Plasma Vitrification System are process gas injection for $\mathrm{NO}_{x}$ abatement or reduction of noncondensible offgas. As discussed in Section 5.1.4, three strategies which have been considered for reduction of the nitrogen oxide production in the plasma torch arc are (1) substitution of another gas (nitrogen, oxygen, or an inert gas) for air in the torch working gas, (2) injection of methane into the working gas to suppress $\mathrm{NO}_{x}$ formation in the arc, and (3) addition of 
ammonia to the hot shaft gas. If an alternative working gas is used, then this must be supplied by an independent gas separation system, such as a swing absorption unit. The quantity of nitrogen, for example (probably the least expensive gas other than air) would be roughly equal to $112 \mathrm{std}-\mathrm{m}^{3} / \mathrm{min}$ (see Table 6.2), although the torch specific power output does differ somewhat depending on the working gas and a slightly different gas flow may be required to deliver the same power. Injection of methane for nitrogen oxide suppression is expected to require 0.5 to 1.0 volume percent of the working gas flow, or 0.5 to $1.1 \mathrm{std}-\mathrm{m}^{3} / \mathrm{min}$; the efficiency of $\mathrm{NO}_{\mathrm{z}}$ reduction as a function of $\mathrm{CH}_{4}$ injection has not yet been established, however. Finally, although ammonia injection has been used commercially for nitrogen oxide reduction, no attempt has yet been made to characterize the quantity required under conditions of the melter system shaft gas (temperature, steam content, etc.). Experimental demonstration is proposed for Phase II testing.

\subsubsection{Labor}

The staffing levels as estimated below are rough engineering estimates which may or may not prove to be correct and thus should only be used for budgetary estimates. The labor estimates are based on operations of commercial Plasma Melter systems in non-radioactive environments, and must be viewed accordingly. Actual more reliable numbers will be generated through efforts during the follow-on phases of this program. These estimates of manpower requirements are recommended for consideration for the first many months of operation of the plant. During plant startup it is expected that assistance from many additional personal will be provided by vendors and various involved engineering firms both on and off site. As the experience and familiarity of the plant staff increases, some reduction and or mix changes in this operating staff may be a logical step.

- A total number of 7 control room operators are required with 3 on day shift and 2 each on the other two shifts. A chief operator is needed for day shift along with his back up plus a third person for general day to day data management and reporting. A head operator and backup is needed for each of the other two shifts.

- The number of shift supervisors required is 3. A chief engineer is needed on day shift assigned with overall responsibility of equipment operation and maintaince. This person should have available staff assistance of a mechanical (or chemical) and electrical engineer.

- The number of on the floor operators required is a total of 12 , utilizing 4 per shift. These operators would each have a primary responsibility for the proper functionality of major subsystem such as (1) feed equipment systems such as radioactive waste feed, off-gas liquid evaporators. Also included would be glass former supplies and feed equipment including the blending and metering equipment; (2) offgas systems including equipment such as quench, heat exchanger, scrubber, and gas analysis equipment; (3) plasma torches, the tuyeres, and the plasma melter including torch electric, water, and gas supply plus the tuyere and melter support cooling, water, and instrumentation system equipment; and (4) glass product 
systems including equipment such as the crucible, tap heaters, molten and solidified product.

- The engineering maintenance supervision staff consisting of 5 persons, 3 of whom are primarily needed for day shift with representation on the other two shifts. A chief engineer is needed on day shift assigned with overall responsibility of equipment operation and maintenance. This person should have staff assistance in the form of a mechanical (or chemical) and electrical engineer.

The number of maintenance workers required is 15 with 9 on day shift and 3 each on the other two shifts. Maintenance tasks such as electrode replacement, for example, require a team of 3 persons. Each of these types of teams would consist of two primary technicians with one functioning as a team leader and a third person providing general labor type task assistance to each team. Three maintenance teams of at least 3 people each should be provided for day shift which would allow for at least three small jobs, if required, to be conducted in parallel or would provide for the formation of a larger effort by combining of teams.

\subsubsection{Maintenance Labor and Parts Costs}

Although preliminary estimates of the costs of maintenance operations and spare parts would be of use in evaluating the operations cost of the Plasma Melter system, sufficient ambiguity exists about the specific design to make such an estimate at this time premature. The Plasma Torch and the associated power supply and utility system is a commercial Westinghouse product line, and the costs of these components are documented in catalog brochures, or may be obtained by contacting the Westinghouse Science and Technology Center. Similarly, spare parts and replacement electrode and gasket sets are also commercial products, and will be quoted by WSTC upon request. The costs associated with parts replacement labor will be substantially different in a radioactively contaminated environment, and without a specific design, any estimate carried out at this time would be purely speculative. 
WHC-SD-WM-VI-015 Revision 0

THIS PAGE INTENTIONALLY LEFT BLANK 


\section{OPERATING AND MAINTENANCE CONCEPTS DEFINITION}

The maintenance requirements for the Westinghouse Plasma Fired Melter are discussed in the following sections. The system boundaries are defined as:

1. Water, electric power and air meeting specifications

2. Frit feed hopper outlet

3. Waste feed pipe

4. Gas outlet to stack

5. Outlet of pour spout

These boundaries contain the following equipment which will be evaluated:

a. Plasma system including:

- Torch power supply, igniter.

- Plasma torches. (*)

b. Melter system including:

- Tuyeres. (*)

- Crucible. $\left(^{*}\right)$

- Pour spouts. $\left(^{*}\right)$

- Shaft from crucible to off-gas system. (*)

c. Frit feed system including:

- Frit metering screws.

- Positive displacement screw pump.

- Frit feed line.

- Control valves.

- Magnetic flow-meters.

- Purge water system.

d. Waste feed system including:

- Waste evaporators.(*)

- Waste feed line. $\left(^{*}\right)$

- Cesium removal. (*)

- Control valves. (*)

- Magnetic flow-meters. $\left(^{*}\right)$

- Purge reactor system.

e. Off-gas solution evaporator system including:

- Off-gas solution evaporator. $\left(^{*}\right)$

- Off-gas concentrate feed line. $\left(^{*}\right)$ 
- Cesium removal. (*)

f. Off-gas system including:

- Quench. (*)

- Venturi scrubber. $\left(^{*}\right)$

- Spray tower. $(*)$

- Demister. (*)

- Reheater. $\left(^{*}\right)$

- Filtration. (*)

- Absorber. (*)

- Sand filter - normally non-radioactive; a redundant stage of filtration. (*)

- Blower.

- Stack.

g. Control system for above.

The items marked with $a\left(^{*}\right)$ above are located in the radioactive area. The remaining items are located in the non-radioactive area.

\subsection{MELTER CELL MECHANICAL OPERATIONS AND MAINTENANCE}

The items above which will have to be replaced during the life of the melter and are located in the melter cell are as follows:

1. Field coils and electrodes in the plasma torches

2. Melter system tuyeres

3. Pour spout heaters

All other items will not require replacement during the life of the facility barring a catastrophic event. The remaining items located in radioactive areas which will require replacement during the life of this facility are as follows:

\section{a. Waste Feed System}

- Heat exchangers

- Cesium removal zeolites

b. Off-gas Evaporator

- Heat exchangers

- Cesium removal zeolites

c. Off-gas System

- Quench water pump (Off-gas recirculation pumps)

- Filter elements

- Absorber elements 
Instead of using a refractory lined melter, Westinghouse proposes to use a water cooled wall which will form a skull coating of glass. The use of the water cooled wall will eliminate the extensive maintenance that would be required if a refractory was used.

\subsubsection{Expected Equipment Maintenance and Reliability}

The mean time between failure or suggested maintenance interval of each of the items in the melter cell will now be considered along with the physical requirements for replacement and repair.

\subsubsection{Plasma Torch Field Coils and Electrodes}

Field coil life is estimated at 5000 hours. Electrode life is estimated to be 500 to 1000 hours for the downstream electrode (cathode), and 1000 to 1500 hours for the upstream electrode (anode). Both items can be replaced without removal of the plasma torch body from the melter. The design of the torch and the melter allows both field coils and electrodes to be replaced in any given torch without halting operation of the melter. They are replaced by the following procedure:

1. Removing the power, air and water connections from the rear of the torch;

2. Remove the hold-down bolts from the back cover and remove cover;

3. Erecting an enclosure to eliminate spread of contamination;

4. Remove the electrodes or field coils from the torch body;

5. Install replacement electrodes or field coils;

6. Removing the enclosure;

7. Replace back cover and hold-down bolts on back cover;

8. Reattach the power, air and water connections to the rear of the torch.

Clearance requirements are about a 1.5 meter cube around the rear of the torch. This area will require some shielding, a positive pressure purge to maintain air flow into the torch opening, and washout/decontamination capability.

\subsubsection{Melter System Tuyeres}

Melter system tuyeres should have an almost unlimited lifetime since the water cooled walls will form a skull which makes refractory unnecessary. However, since this area will have exposure to the highest temperatures and most corrosive conditions in the system, the use of replaceable tuyeres is considered to be a prudent engineering design feature.

The tuyeres will be replaced only during a melter outage. Therefore, it is assumed that the contaminated, internal glass skull has been removed (see Section 7.1.2 below), and that the inside and outside of the tuyere have been surface decontaminated to remove smearable activity. The tuyere is replaced by the following procedure: 
1. Removing the power, air and water connections from the rear of the torch;

2. Remove the bolts connecting the torch to the tuyere;

3. Erecting an enclosure to eliminate spread of contamination;

4. Remove the torch body using the overhead crane;

5. Disconnecting the bolts holding the tuyere to the crucible;

6. Remove the tuyere using the overhead crane and wrap the tuyere in a cover to avoid spread of contamination;

7. Install a new tuyere using the overhead crane;

8. Attach the bolts holding the tuyere to the crucible;

9. Re-install the torch using the overhead crane;

10. Remove the enclosure;

11. Replace hold-down bolts on back cover;

12. Reattach the power, air and water connections to the rear of the torch.

Clearance requirements are a rectangular volume about 1.5 meter high by about 2.5 meter square around the rear of the torch. In addition, an overhead crane (lifting capacity of about $1000 \mathrm{~kg}$ ) is also required. This area will require some shielding and a positive pressure purge to maintain air flow into the torch opening and washout capability.

\subsubsection{Pour Spout Heaters}

The lifetime of the pour spout heater life has not been estimated, due to absence of a specific design or experimental data for the immediate environment. The design of the pour spout heaters will allow them to be replaced in any given pour spout without halting operation of the melter. They are replaced by:

1. Removing the power connections from the rear of the heater;

2. Remove the hold-down bolts from the back cover;

3. Erecting an enclosure to eliminate spread of contamination;

4. Remove the heater from the deck mounting;

5. Install the replacement heater;

6. Removing the enclosure;

7. Replace hold-down bolts on back cover;

8. Reattach the power to the rear of the heater.

Clearance requirements are about a 0.5 meter cube around the rear of the heater. This area will require some shielding, a positive pressure purge to maintain air flow into the heater opening and washout capability.

\subsubsection{Decontamination Operations}

Decontamination of the melter and its subsystems is a critical maintenance and end of life consideration. The costs associated with the plasma melter are reduced 
compared to other technologies due to the much smaller size of the facility. Replacement of the melter itself is not envisioned during the operating life of the facility. Rather, individual torches (or more likely, their electrodes) will be the major items that are replaced on a regular basis. However, even during the relatively minor shutdowns for regular scheduled maintenance, the ability of the plasma melter to be easily decontaminated will help reduce operator and maintenance radiation exposure and aggressively pursue the ALARA (As Low As Resonably Achievable) concept.

The feature which allows easy decontamination is the use of a cold wall to form a skull coating of clean or contaminated glass. Decontamination of the melter proceeds as follows:

1. The flow of cooling water is reduced to the cold walls of the melter system. At the same time, non-radioactive, high sodium glassformer or solution is injected.

2. The contaminated glass is allowed to melt off the walls of the melter until residual activity level leaving pour spout is as low as desired.

\subsubsection{Maintenance Labor and Parts Costs}

The specific labor requirements for replacement of plasma torch components have been dealt with in the previous sections. Without a specific design and detailed consideration of operation within a radiation environment, it would be premature and highly speculative to discuss cost of maintenance labor, or parts cost for components other than those for the Plasma Torch and its ancillary systems (including tuyeres, crucible, pour spout, melter shaft/upperworks from crucible to offgas system, frit feed system, waste evaporators, offgas solution evaporator, and the control system). Detailed costing of Plasma Torch components are available commercially to interested customers, who should contact the Westinghouse Science and Technology Center for quotes.

\subsection{PROCESS CONTROL AND INSTRUMENTATION}

The control system envisioned for the plasma melter would utilize two programmable logic controllers (PLC) with digital transmitters. The two PLCs will be redundant to allow for failure of one without affecting the operability of the process. This is a proven approach for processes requiring a high degree of reliability, and has been used commercially for operation of Plasma Melters.

\subsubsection{Required Instrumentation}

The air and water utilities instrumentation required for the operation of the torch and tuyere is shown in Figure 7.1. In addition, the torch instrumentation includes currents and voltages for the control and main power supplies. Instrumentation on the crucible is summarized in Table 7.1. The items marked with an (*) are measurements made in a radioactive area. Note that these measurements all utilize thermocouples in thermowells. These thermowells can be engineered such that the thermocouple can be 
Table 7.1 - Crucible Instrumentation

\begin{tabular}{|c|c|c|}
\hline Measurement & Instrument & Number \\
\hline \multicolumn{3}{|c|}{ Inlet Cooling Water - Crucible (for each of 4 wall sections) } \\
\hline Temperature & Thermocouple & 4 \\
\hline Pressure & Pressure Transducer & 4 \\
\hline Flow & Pressure Differential & 4 \\
\hline \multicolumn{3}{|c|}{ Outlet Cooling Water - Crucible (for each of 4 wall sections) } \\
\hline Temperature & Thermocouple & 4 \\
\hline Pressure & Pressure Transducer & 4 \\
\hline \multicolumn{3}{|c|}{ Inlet Cooling Water - Pouring Spout (for each of 2 pour spouts) } \\
\hline Temperature & Thermocouple & 2 \\
\hline Pressure & Pressure Transducer & 2 \\
\hline Flow & Pressure Differential & 2 \\
\hline \multicolumn{3}{|c|}{ Outlet Cooling Water - Pouring Spout (for each of 2 pour spouts) } \\
\hline Temperature & Thermocouple & 2 \\
\hline Pressure & Pressure Transducer & 2 \\
\hline \multicolumn{3}{|c|}{ Power Level - Pouring Spout Heater (for each of 2 pour spouts) } \\
\hline Voltage & Meter & 2 \\
\hline Amperage & Meter & 2 \\
\hline \multicolumn{3}{|c|}{ Crucible Glass Temperature $\left({ }^{*}\right)$} \\
\hline Temperature & Thermocouples in Wells & 4 \\
\hline \multicolumn{3}{|c|}{ Pour Spout Glass Temperatures $\left({ }^{*}\right)$} \\
\hline Temperature & Thermocouples in Wells & 4 \\
\hline
\end{tabular}

$\left.{ }^{*}\right)$ Measurements made in radioactive area.

maintained from the non-radioactive areas so that maintenance inside the radioactive area can be avoided.

\subsection{VIEWING SYSTEMS}

As demonstrated during the 26-hour Demonstration Run, a minimal amount of the process is visible due to the high temperatures and small size of the unit. In addition, the critical operational process requirement of maintaining a flowable glass was demonstrated to be easily controlled using measurements with thermocouples in the refractory of the crucible and the pour spout. From this experience, the minimum desirable visual contact during normal operation can be limited to the pour spout area to verify the fluidity of the glass. During upset operations such as unexpectedly high viscosity or plugging of a pour spout, maintaining visual contact of the pour spout area is still the only productive requirement. 


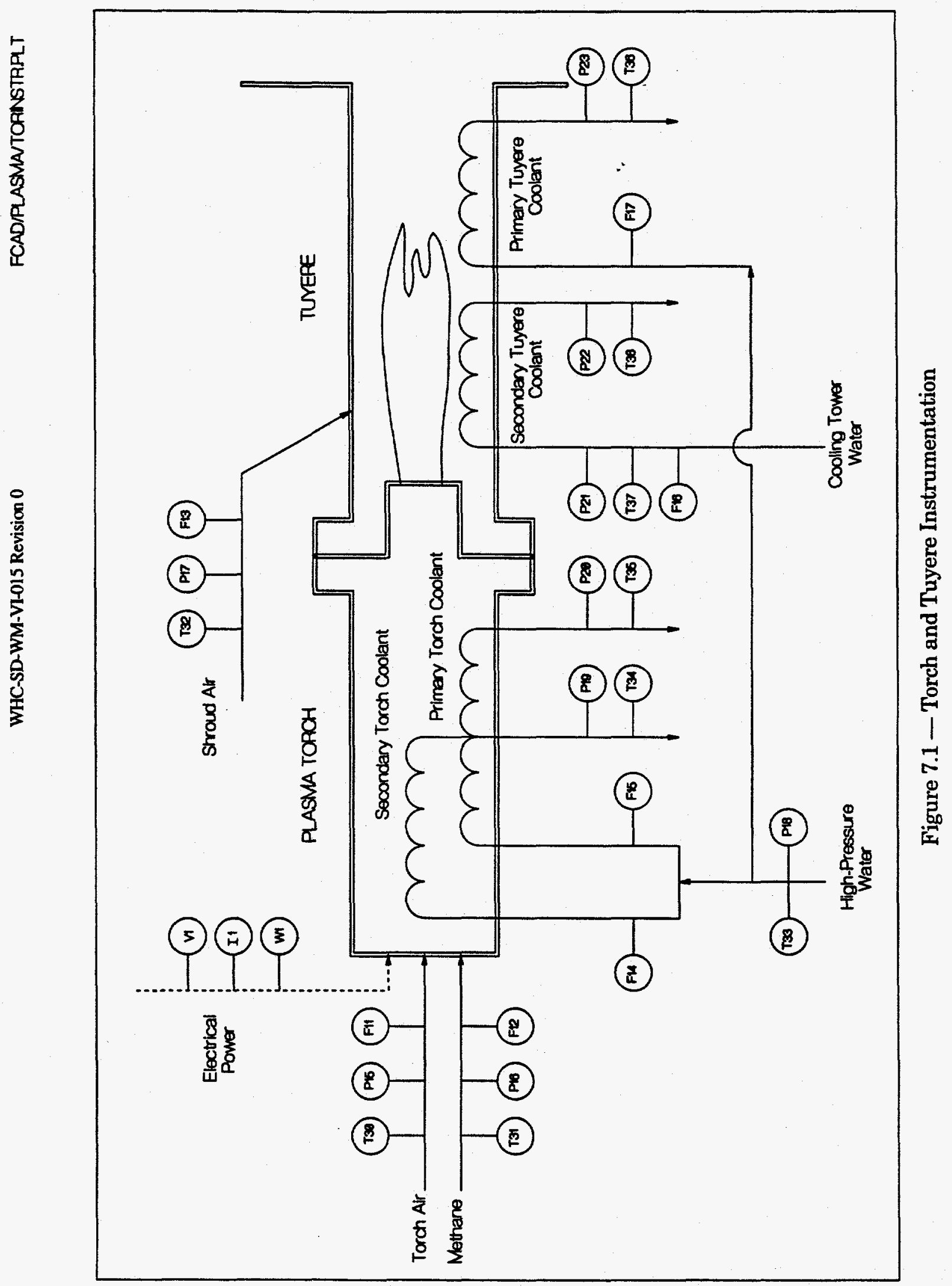




\subsection{MELTER STARTUP, OPERATION, RESTART AND SHUTDOWN CYCLES}

This section describes the operations involved during typical operations expected during the operation of the plasma melter. The objectives of this analysis are to identify any inoperable modes and to help determine the labor requirements of the full scale facility. The operational cycles considered were as follows:

1. Cold startup and operation

2. Torch maintenance

3. Changeout of waste container during glass pouring

4. Idle and hot restart

5. Emergency shutdown followed by warm restart

6. Shutdown

\subsubsection{Cold Startup and Operation}

The estimated time to accomplish cold startup is 6 hours, according to the following procedure:

1. Turn on offgas system.

2. Turn on glow heaters in pour spout area.

3. Turn on cooling water to jackets.

4. Turn on torches to preheat tuyere and crucible regions; allow $2-4$ hours for system to achieve operating temperature.

5. Turn on frit or batch glassformer feed with non-radioactive sodium feed.

6. After non-radioactive glass product established, switch to radioactive feed.

7. Adjust torch power levels to maintain required glass temperatures and pour rates.

\subsubsection{Torch Maintenance}

The estimated time to carry out torch maintenance is 4 hours. When a particular torch's power level becomes unacceptable due to electrode wear or other problems with one of the ten operating torches on a melter:

1. Switch from waste to clean sodium frit feed for that torch.

2. Turn down cooling water to jacket of tuyere.

3. Turn off frit and clean sodium frit feed when radioactive skull has been removed from the tuyere to a satisfactory decontamination factor.

4. Turn off torch power.

5. Turn off cooling water to tuyere.

6. Close torch isolation valve.

7. Remove torch back cover and torch inner assembly into glove box.

8. Change electrodes or perform other required maintenance.

9. Install torch inner assembly into torch body and install back cover.

10. Open torch isolation valve. 
11. Turn on cooling water to tuyere.

12. Turn on torch.

13. Turn on frit and clean sodium frit feed after appropriate temperature is reached in tuyere.

14. Switch from clean sodium frit feed to waste.

Note that the isolation valve is a feature designed for radioactive isolation service. A diagram of this valve is shown in Figure 7.2. The isolation valve is a $15 \mathrm{~cm}$ sliding gate valve. Power for this valve is either by an actuator (located outside of the radioactive boundary) or by hand.

\subsubsection{Changeout of Waste Container During Glass Pouring}

There is no need for complete process shutdown, due to dual pour spouts servicing each melter. If a shutdown is required, there will be sufficient capacity to store at least 15 minutes worth of melt in the crucible without stopping the waste or glass frit feeds.

\subsubsection{Idle and Hot Restart}

Periodically stopping and restarting the melter feed will pose no significant operating problems. While idling the melter should pose no operating problems, experience in the glass industry has indicated that the more volatile components such as sodium and cesium may tend to slowly evaporate from the hot surface layer of the melter. Other than this possible effect, there is no reason why the plasma melter could not be idled hot for an indefinite time period. To turn off a torch and maintain a hot condition:

1. Turn down cooling water to jacket of tuyere.

2. Turn off waste feed.

3. Turn off torch.

To restart a torch from a hot idle condition:

1. Turn up cooling water to tuyere.

2. Turn on torch.

3. Turn on waste feed.

Both operations are estimated to require approximately 15 minutes:

To idle the melter while maintaining a torch in the operating condition, it is necessary only to turn off the waste feed. Restart from a hot idle condition requires restart of waste feed; a short time will then be required to reestablish steady state temperatures and offgas flowrates. 


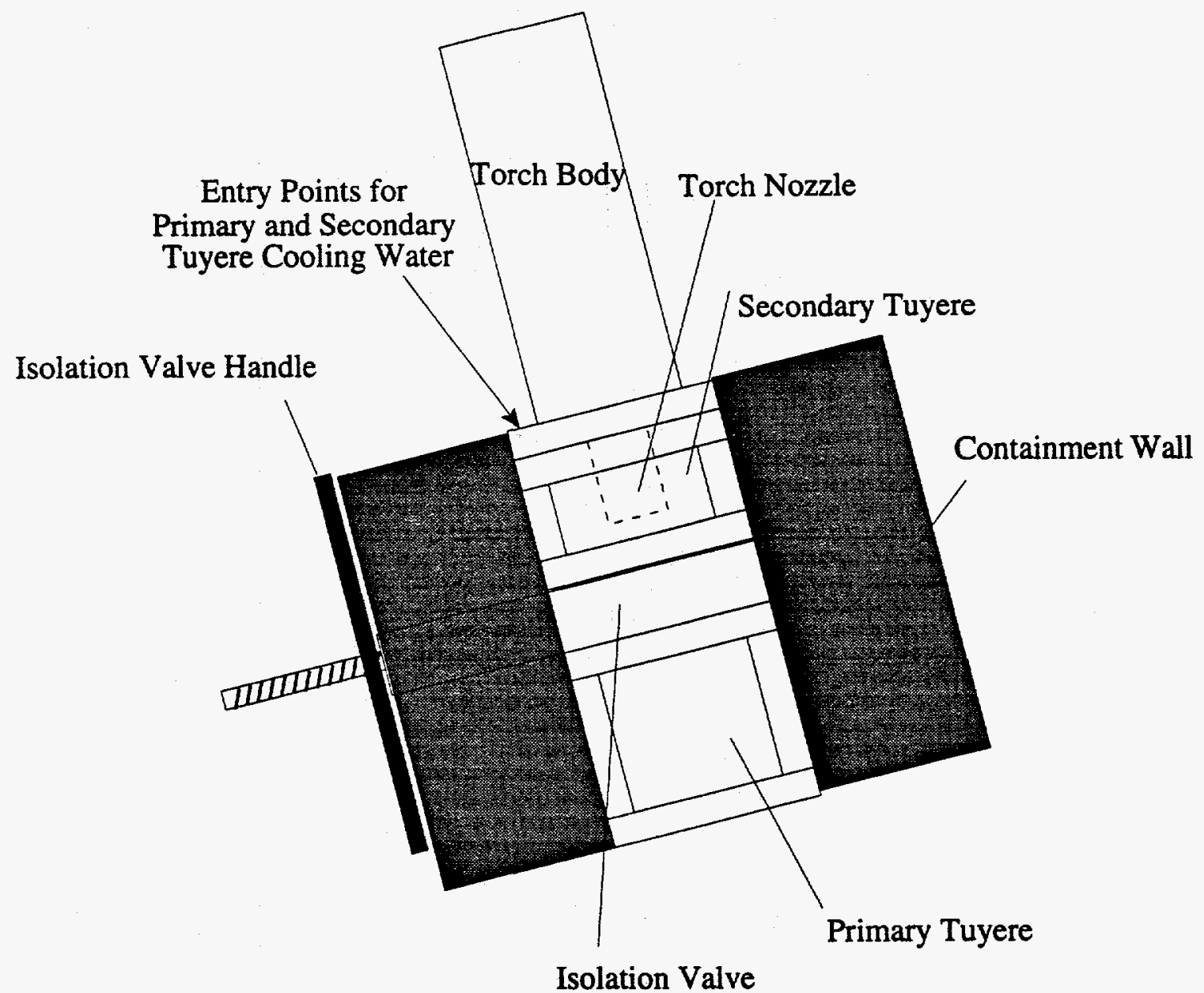

Figure 7.2 - Detail of Torch Mounting Showing Isolation Valve 


\subsubsection{Emergency Shutdown Followed by a Warm Restart}

The nearly instantaneous nature of the Plasma Torch power system allows interruption of torch power with a single switch. Flow of waste feed to the melter can be controlled in a similar manner, such that emergency shutdown can be accomplished in less than one minute:

1. Turn off waste feed.

2. Turn off torch.

3. Turn off cooling water

Warm restart of the melter can then be accomplished within 15 minutes by the following procedure:

1. Turn up cooling water to tuyere.

2. Turn on torch.

3. Turn on waste feed.

4. Allow sufficient time to reestablish steady state (maximum of 2 hours, depending on system temperature at the time of restart).

\subsubsection{Shutdown Cycle}

Shutdown of the Plasma Vitrification system can be accomplished in an estimated time of 2 hours by the following procedure:

1. Switch from waste to clean sodium feed.

2. Turn down cooling water jackets.

3. Allow skull to melt off tuyere wall.

4. Turn off frit and clean sodium feed.

5. Turn off torch.

6. Turn off glow heaters in pour spout area.

During any of the operations above which specify that the feed (either clean sodium or waste) is turned off, additional line cleaning operations are performed. These include a flush back with water through the feed line to the evaporator or feed tank to clear the line of all caustic feed and frit. This step is required to prevent the precipitation of solids and/or the reaction of the caustic with the frit or bull feed materials to form a solid mass. 
WHC-SD-WM-VI-015 Revision 0

THIS PAGE INTENTIONALLY LEFT BLANK 


\section{MELTER RELIABILITY ASSESSMENT AND FAILURE ANALYSIS}

Three components are expected to require maintenance during the expected lifetime of the Westinghouse Plasma Melter. All others can be expected to last for an indefinite time with proper design. The items which will have to be replaced during the life of the melter and are located in the melter cell are as follows:

1. Field coils and electrodes in the plasma torches.

2. Melter system tuyeres.

3. Pour spout heaters.

All other items will not require replacement during the life of the facility barring a catastrophic event. Note all the above items are easily replaceable; requiring little downtime and producing a minimum of contaminated waste scrap material.

As indicated in Section 7.1, field coil life is estimated at 5000 hours, while electrode life is estimated at between 500 and 1500 hours. Both items can be replaced without removal of the plasma torch body from the melter. The design of the torch and the melter will allow both field coils and electrodes to be replaced in any given torch without halting operation of the melter.

Melter system tuyeres should have an almost unlimited lifetime since the water cooled walls will form a skull which makes a refractory unnecessary. However, since this area will have exposure to the highest temperatures and most corrosive conditions in the system, the use of replaceable tuyeres is considered to be a prudent engineering design feature. The tuyeres will be replaced only during a melter outage. Therefore, it is assumed that the contaminated, internal glass skull has been removed (see Section 7.4.2 above) and the inside and outside of the tuyere has been surface decontaminated to remove smearable activity. Pour spout heater life has not been estimated. The design of the pour spout heater will allow them to be replaced in any given pour spout without halting operation of the melter.

Normal maintenance of a plasma melter would encompass the same items as listed above. In addition, since refractory linings are used in most installations, there are periodic outages associated with refractory repair or replacement. Since the proposed design does not utilize refractories, refractory maintenance is unnecessary.

A variety of system failures may still occur which are outside the range of normal maintenance activities. This section outlines potential failures to the plasma melting system, operational responses and estimates the consequences of them. This is not meant as a complete failure analysis since probabilities of occurrences are not determined, nor are derivative failures analyzed. In addition, human factors are not considered. 


\subsection{ELECTRODE WEAR}

Response: Shut down plasma torch and tuyere; shut off feed to affected torch; replace electrodes.

Result: Lost production of 4 hours for one tuyere.

\subsection{FEEDLINE PLUG}

Response: Shut down feed line; hot-idle affected melter; reverse flow purge with water to evaporator.

Result: Lost production for assumed downtime of 2 hours; additional water from purge in evaporator.

\subsection{FEED OR OFFGAS EVAPORATOR OUTAGES}

\subsubsection{Pump Outage}

Response: Switch to parallel pump; carry out maintenance on idled pump.

Result: No impact on process.

\subsubsection{Line Plug}

Response: Shut down recirculation pump and steam feed; reverse purge recirculation line with water; increase feed rate to unaffected evaporator.

Result: Additional water from purge in evaporator.

\subsubsection{Heat Exchanger Fouling}

Response: Derating of evaporators until scheduled maintenance if not severe. If severe, shut down recirculation pump and steam feed, increase feed rate to unaffected evaporator, and reverse purge recirculation line and heat exchanger with water.

Result: Additional water from purge in evaporator.

\subsection{SITE POWER OUTAGE}

Response: Start up emergency generators to maintain off-gas system only; all valves close in safe position; reverse purge slurry feed portion of feed line with water to evaporator (assuming cold restart is required).

Note: Pressurizer with purge water eliminates need for emergency power to pump. 
Result: $\quad$ Lost production for assumed outage of 2 hours; additional waste from restart; additional water in evaporator from line purges.

\subsection{GLASSFORMER FEED LINE PLUG}

Response: Shut down waste feed and reverse purge feed line to evaporator with water; hot idle melter; shut down glassformer feed pump and reverse purge glassformer feed line with water to melter.

Result: Lost production for assumed 2 hours downtime; additional water in evaporator from line purges.

\subsection{FRIT PUMP OUTAGE}

Response: Switch to parallel pump; carry out maintenance on idled pump.

Result: $\quad$ No impact on process.

\subsection{COOLING WATER OUTAGES}

\subsubsection{Chiller Outage}

Response: Shut down process to cold standby.

Result: Lost production for assumed 8 hours downtime; additional water in evaporator from line purges; additional waste from startup.

\subsubsection{Circulating Pump Outage}

Response: Switch to parallel pump; carry out maintenance on idled pump.

Result: No impact on process.

\subsection{CONTROL SYSTEM MALFUNCTION}

Response: Shut down process using local controls; assume cold shutdown.

Result: Lost production for assumed 8 hours downtime; additional water in evaporator from line purges; additional waste from startup. 


\subsection{OFFGAS SYSTEM OUTAGE}

Response: Shut down system with all valves closed in safe position; reverse purge slurry feed portion of feed line with water to evaporator; assume cold shutdown.

Result: Lost production for assumed 8 hours downtime; additional waste from restart; additional water in evaporator.from line purges.

\subsection{POWER SUPPLY OUTAGE}

Response: Shut down affected melter system with all valves close in safe position; reverse purge slurry feed portion of feed line with water to evaporator; assume cold shutdown of affected melter.

Result: Lost production for assumed 8 hours downtime; additional waste from restart; additional water in evaporator from line purges.

\subsection{TAP HOLE BLOCKAGE}

Response: Turn on standby glow bar heater; assume double pour rate from companion pour spout.

Result: $\quad$ Some excess waste from high sodium frit.

\subsection{GLOW BAR FAILURE}

Response: Turn on standby glow bar heater.

Result: None.

\subsection{BUILDUP OF MATERIAL IN TUYERE}

Response: Shut off feed to affected torch; either shut down plasma torch and cooling water to tuyere and purge tuyere with water or maintain plasma torch power and turn down tuyere wall cooling water.

Result: $\quad$ Lost production for assumed 2 hours of downtime.

\subsection{WATER COOLED WALL RUPTURE INTO MELTER}

\subsubsection{Small Rupture ( $<2$ liters/minute)}

Response: No action required.

Result: Lower production rate until maintenance period reached; increased offgas steam production. 


\subsubsection{Large Rupture (>2 liters/minute) \\ Response: Shut down waste feed and reverse purge feed line to evaporator with water, shut down frit feed pump and reverse purge frit line with water to frit supply header; turn down cooling water to allow skulls in melter to melt off; turn off torches for cold shutdown.}

Result: Loss of one-third plant rated production capacity until repairs completed.

\subsection{WATER COOLED WALL RUPTURE OUT OF MELTER}

Response: Shut down waste feed and reverse purge feed line to evaporator with water, shut down frit feed pump and reverse purge frit line with water to frit supply header; turn down cooling water to allow skulls in melter to melt off; drain crucible; turn off torches for cold shutdown. Note that the magnitude of the spill resulting from such a failure is relatively small (about 0.7 tonnes/half of inventory of glass) since the inventory of the melter is much smaller than conventional technologies (e.g. joule heated melter).

Result: Loss of one-third rated production capacity until repairs completed. 
WHC-SD-WM-VI-015 Revision 0

THIS PAGE INTENTIONALLY LEFT BLANK 


\section{APPENDIX A}

\section{Letter 9550084/384212-001}

M. J. Bowman to D. F. McLaughlin

January 6, 1995 
P.O. Box 1970 Richland, WA 99352

January 6, 1995

9550084

384212-001

Dr. David F. McLaughl in

Westinghouse Science \& Technologies Center

1310 Beulah Road

Pittsburgh, Pennsylvania 15235

Dear Dr. McLaughlin:

LOW-LEVEL WASTE MELTER TECHNOLOGY DEMONSTRATION SUBCONTRACT MMI-SVV-384212, REQUEST FOR TECHNICAL INFORMATION

Reference: WHC-SD-WM-RD-044, Evaluation of Melter System Technologies for Vitrification of High-Sodium Content Low-Level Radioactive Liquid Wastes, dated February 15, 1994.

The following is provided as guidance to assist the Westinghouse Science \& Technologies Center (WSTC) in providing complete, uniform reports in accordance with the referenced Statement of Work (SOW). The technical information discussed below is requested to further evaluate the WSTC Plasma melter system as discussed in the sow, Section 10 and Section 13, items 13 and 14 . Before preparing a separate written reply, preliminary concepts and/or draft replies should be discussed with the Westinghouse Hanford Company (WHC) technical representative Mr. D. W. Hendrickson. Information on individual items should be supplied by January 30,1995 , if possible. Information that cannot be supplied, or that will be available after January 30, 1995, should be discussed with Mr. D. W. Hendrickson. Some additional questions may arise as the engineering and technology evaluations proceed. These will be discussed with you and/or submitted as they arise. A summary of all information provided should be included in the reports identified in SOW Section 13, items 13 and 14. If desired, you may combine Sow Section 13, items 13 and 14 into a single report. Responses may be cross-referenced to avoid repetitious answers.

In developing requested information, questions may arise on feasibility or desirability of specific design or operating features for a nuclear chemical processing facility. If needed, personnel from WHC with related experience can be made available (on a limited basis) to provide review, comments, and related input concerning features for use in nuclear processing facilities. If you need this type of assistance, Mr. D. W. Hendrickson should be contacted.

It is assumed that information requested is already available or can be developed with a relatively modest effort. If you expect an overrun of cost initially estimated for SOW Section 13, items 13 and 14, please contact the undersigned. Mr. D. W. Hendrickson and I will work with you to resolve the scope and estimated cost before performing the work. 
Dr. David F. McLaught in

9550084

Page 2

January 6,1995

384212-001

\subsection{Process Definition}

1.1 Plant melter design concepts. The current preliminary planning basis assumes a total plant design capacity of 200 tonnes per day of glass product with $25 \mathrm{wt} \%$ waste oxides with a minimum of two operating melters. Note that this is instantaneous capacity with a Hanford Site assumption of $60 \%$ total operating efficiency. The remaining $40 \%$ is assumed reserved for maintenance outages or other down time.

1.1.1 What is the proposed number and capacity of melters (e.g. two at 100 tonnes/day, three at 67 tonnes day, etc.)

1.1.2 What concepts are proposed for design of a full scale meiter? What are the approximate size, shape and key features of full scale units for use in a low level nuclear waste processing facility? Provide descriptive information and sketches as appropriate.

1.2 What is the basis and logic for scale-up from Phase 1 test system or other basis to the full scale process concept? Please include a brief discussion of contingencies and uncertainties in scale-up.

1.3 Is a supplemental glass reservoir required to assure a reasonably uniform, completely reacted glass product? If necessary what is the proposed basis for establishing reservoir size?

1.4 Requirements may be imposed that the system have capability to start and stop glass pouring periodically without stopping melter feed, and that some minimum buffer capacity be provided to allow glass to accumulate while the pour is stopped (for example to allow glass receiver containers to be changed out).

1.4.1 Will there be significant impacts to the melter concept if the above requirement is implemented?

1.4.2 What is the impact of periodically stopping and restarting melter feed?

1.4.3 Can the melter be idled for extended periods (i.e. maintained hot) without feeding? What are the effects of idling? How long does it take to reestablish full production from an idling status?

1.5 What design and operating concepts are proposed for the feed system? What premixing, additives, preprocessing, feed composition control, process and equipment, etc. concepts are proposed? How do such concepts vary from those applied during Phase I demonstration work and what are the anticipated benefits accrued with the variation? 
Page 3

January 6, 1995

Recycle of volatilized material recovered from the offgas is expected. What, if any, impact is expected from recycle?

1.6 Separability of Melter and Offgas Treatment. The process definition of the melter system (above) must be at least through the point where offgas exits the melter or glass reservoir.

1.6.1 Proposed offgas treatment concepts may be provided but are not required unless portions of the offgas treatment equipment are considered an integral part of the melter system. For purposes of consideration of high volatility materials in the WSTC PIasma Melter and material recycle (see $\S 1.5$ ), discussion is recommended.

1.6.2 Equipment for offgas recycle should be included if part of the proposed concept.

\subsection{Technology Development Status}

2.1 What does WSTC consider the key technical issues that need to be resolved by Phase 2 testing or other testing or development work in order to allow implementation of their technology to proceed on a reasonably low risk basis?

2.2 A preliminary estimate of the potential range of Hanford low level waste (LLW) vitrification plant feeds was illustrated as 'Remaining Inventory' composition of Table A-1 in the SOW. Carefully review feed compositions including minor and trace components and identify the following:

2.2.1 Components known or suspected to cause problems under some conditions in the melter, feed preparation, or offgas system (for example corrosion, precipitation of insoluble sludge, adherent scale formation, plugging of lines or ducts, glass quality problems, unpredictable or unstable operations, electrode shorting, problems with melt properties, safety problems);

2.2.2 If potential problems are identified, please discuss design features or operating methods expected to reduce or eliminate potential problems;

2.2.3 Components known or suspected to have significant volatility at melter conditions (please provide summary of any data or experience if available);

2.2.4 Components for which the vendor is unaware of any previous operating experience or testing that can be used as a guide to behavior in the vendors proposed system. 
2.3 How is the Hanford application similar or different from past experience/applications; what are the key issues and/or uncertainties in adapting the technology to the Hanford application? \{Plus additional questions on specific technology issues WHC has identified.

\subsection{Operating Performance Characteristics}

\subsection{Off-gas Volume and Characteristics}

3.1.1 What is the expected off-gas flow rate and temperature from a full scale melter (time average flow, minimum flow, maximum surge flow, normal and maximum temperature)?

3.1.2 Are techniques available for off-gas volume reduction (oxygen boosting, recycle, etc.)? What reduction in off-gas volume might be realized?

3.1.3 What data is available from previous testing or plant operations that could be used to assess volatility of feed components (see attachment for potential feed components)? Species currently identified as potentially volatile include: $\mathrm{F}, \mathrm{Cl}, \mathrm{P}, \mathrm{Na}, \mathrm{K}, \mathrm{S}, \mathrm{Ag}, \mathrm{As}, \mathrm{Be}, \mathrm{Bi}, \mathrm{Cd}, \mathrm{Co}, \mathrm{Cr}, \mathrm{Cu}$, $\mathrm{Hg}, \mathrm{I}, \mathrm{Pb}, \mathrm{Ru}, \mathrm{Sb}, \mathrm{Se}, \mathrm{Sn}, \mathrm{Tc}, \mathrm{Tl}, \mathrm{V}$, and $\mathrm{Zn}$.

What data is available that might indicate, at least roughly, elemental split factors between offgas and glass? Over what range of conditions is data available, for example: concentration in feed, operating temperature, redox conditions, glass or slag composition?

3.2 Waste Treatment and Recycle. Is there data or experience with recycle of volatile components back through the melter?

3.3 Acceptable Melt Properties. What are considered the acceptable range of melt properties for proper operation? For example: Melting temperatures, viscosity, electrical conductivity, thermal conductivity, opacity, oxidation/reduction state, chemical composition, etc. What is the effect of fluctuations in properties? How sensitive is the melter to fluctuations in melt properties?

3.4 Requirements for Melter System Utilities and Services.

3.4.1 What utilities and feed materials are required, for example: Estimated quantities of fuel, combustion gases, process chemical additions for feed preparation, process cooling water, electric power, etc. 
Dr. David F. McLaughlin

Page 5

January 6, 1995

3.4.2 What are the average and peak service loads for a full scale unit?

3.4.3 Where are services connected to the melter and other process equipment?

3.4.4 For each of the essential services what are the specific equipment requirements, unique types of equipment, number, physical size and relative location of the equipment?

\subsection{Operating and Maintenance Concepts Definition}

4.1 What are the mechanical operations and maintenance requirements of the melter system? What operations and maintenance items or functions are required in the melter cell; for example:

4.1.1 Melter Cell Mechanical Operations. Identify any items expected to require replacement or repair during the 1 ife of the melter which must be physically located inside, attached to, or located adjacent to the melter or glass reservoir. What is the expected replacement/repair frequency of these items? Does melter confinement have to be broken (opened to cell atmosphere) to replace or repair the item? Any ideas or suggestions as to how functions might be performed remotely if needed?

What are the physical maintenance requirements for these items (e. g. clearance allowances, special tools required). What are the weights of the melter and/or heaviest melter components. This information is needed to evaluate equipment layout and facility footprint and any special melter cell maintenance equipment or related features.

4.1.2 Melter Refractory. What is the expected life of melter refractory? Does the vendor consider it necessary or feasible to provide for repair. or replacement of internal contaminated refractory during the life of the melter. If necessary, are there any comments or suggestions on how this might be done?

4.1.3 Melter Replacement. Please describe the preliminary concept for disassembly/reassembly of the melter for maintenance or replacement?

Is it feasible to build the melter and reservoir (if required) as a module that can then be moved into place (or set of modules that can be remotely or semi-remotely assembled), or is it necessary to do some assembly in place (for example installing refractory linings). What is the estimated weight of the melter or the melter pieces? 
Dr. David F. McLaught in

Page 6

January 6,1995

Any thoughts or comments on possibly concepts for failed melter removal, disposal, or reinstallation?

4.1.4 Melter Startup and Shutdown. Describe how initial heat up and feeding of a full scale melter could be accomplished. Can the melter be shut down (cold) and then restarted? Will this damage the melter? How will restart of a contaminated melter be accomplished? Can the melter be drained at the end of its life? How?

\subsection{Process Control and Instrumentation}

4.2.1 What instrumentation is required to operate the melter?

4.2.2 Where and approximately how many sensors are installed?

4.2.3 What instrumentation or control components must be mounted on or located next to the melter? What replaceable failure components must be in contact with contaminated process materials?

\subsection{Viewing systems}

4.3.1 What is the minimum visual contact that the operator must have to operate and/or maintain the melter system? (Visual contact, al though not an ideal situation, can be maintained by use of lead glass windows, periscopes, and video cameras.)

4.3.2 To what extent is visual contact with the melter desirable? Consider both normal and off-normal events.

4.3.3 What is the purpose or function of viewing the melter? Is this a function that could be done with sensors?

4.4 Melter Shutdown and Startup.

4.4.1 Typical sequence of events, time duration, and requirements during routine shutdown and start-up.

4.4.2 Typical sequence of events and requirements in the case of emergency shutdown and subsequent start-up.

\subsection{Melter Reliability Assessment (SOW Section 13 Item 14)}

5.1 What is the projected life of the melter or major melter subassemblies in an "operate to failure scenario"?

5.2 What are the failure conditions expected to require melter replacement? 
Dr. David F. McLaughlin

January 6, 1995

5.3 What are the projected lives of the replaceable melter parts in "operate to failure scenarios."

5.4 What would be normal, scheduled maintenance activities for a nonradioactive application?

If you have any questions or require further information, please contact the undersigned at (509) 376-9769.

Very truly yours,

m J Boumw

M. J. Bowman, Senior Procurement Specialist

$A / E$ and Major Subcontracts Procurement

aev 
WHC-SD-WM-VI-015 Revision 0

\section{APPENDIX B}

\section{PNL Glass Composition}



Candldate Melter Vendor Glasses

(Summary of predlcted and measured propertles)

\begin{tabular}{|r|c|c|c|c|c|c|}
\cline { 2 - 7 } \multicolumn{1}{c|}{} & \multicolumn{6}{c|}{ Glass (gi) } \\
\hline Oxide & Waste (wi) & LD4-912 & LD5-912 & LD6-5412 & LD6-5510 & LD6-5314 \\
\hline SiO2 & 0.0000 & 0.5591 & 0.5591 & 0.5591 & 0.5691 & 0.5491 \\
$\mathrm{~B} 2 \mathrm{O3}$ & 0.0000 & 0.0900 & 0.0000 & 0.0500 & 0.0500 & 0.0500 \\
$\mathrm{Na2O}$ & 0.7605 & 0.2000 & 0.2000 & 0.2000 & 0.2000 & 0.2000 \\
$\mathrm{CaO}$ & 0.0001 & 0.0000 & 0.0900 & 0.0400 & 0.0500 & 0.0300 \\
Al2O3 & 0.1220 & 0.1200 & 0.1200 & 0.1200 & 0.1000 & 0.1400 \\
Others & 0.1174 & 0.0309 & 0.0309 & 0.0309 & 0.0309 & 0.0309 \\
\hline Total & 1.0000 & 1.0000 & 1.0000 & 1.0000 & 1.0000 & 1.0000 \\
\hline
\end{tabular}

\begin{tabular}{|r|c|c|c|c|c|}
\hline wasle loading $(\mathrm{W})$ & 0.263 & 0.263 & 0.263 & 0.263 & 0.263 \\
\hline Melting Temp $\left({ }^{\circ} \mathrm{C}\right) \#$ & 1304 & 1273 & 1290 & 1264 & 1316 \\
Arrh.Vis at MT (Pa.s)\# & 10.00 & 10.00 & 10.00 & 10.00 & 10.00 \\
FulcherVis al MT (Pa.s)\# & 7.42 & 11.86 & 9.65 & 9.71 & 9.56 \\
E.C. al MT (S/m)\# & 39.58 & 33.73 & 36.85 & 34.06 & 39.81 \\
\hline $\mathrm{T}\left({ }^{\circ} \mathrm{C}\right)$ at Mesur Arrh Vis = 10 Pa.s & 1325 & 1371 & 1323 & 1296 & 1379 \\
\hline
\end{tabular}

$T\left({ }^{\circ} \mathrm{C}\right)$ at Mesur Arrh Vis $=10 \mathrm{~Pa} \cdot \mathrm{s}$

\begin{tabular}{|c|c|c|c|c|c|}
\hline $\begin{array}{r}\text { MCC-1 B (g/m2) } \\
\text { (Full CVS, All glasses)\# } \\
\text { (Full CVS, High-Rel Del)\# } \\
\text { (Na2O } 216 \text {, High-Rel Del)\# } \\
\text { Measured* } \\
\end{array}$ & $\begin{array}{c}10.41 \\
8.03 \\
10.40 \\
5.06 \\
\end{array}$ & $\begin{array}{l}4.54 \\
4.71 \\
3.64\end{array}$ & $\begin{array}{l}7.20 \\
6.33 \\
6.52 \\
7.94 \\
\end{array}$ & $\begin{array}{l}9.44 \\
7.45 \\
7.03 \\
6.23\end{array}$ & $\begin{array}{l}5.49 \\
5.38 \\
6.06 \\
7.56\end{array}$ \\
\hline \multicolumn{6}{|l|}{$M C C-1 \mathrm{Na}(\mathrm{g} / \mathrm{m} 2)$} \\
\hline (Full CVS, All glasses)\# & 9.78 & 4.27 & 6.76 & 8.81 & 5.20 \\
\hline (Full CVS, High-Rel Del)\# & 7.46 & 4.33 & 5.86 & 6.85 & 5.01 \\
\hline (Na2O $\geq 16$, High-Rel Del)\# & 8.86 & 3.48 & 5.85 & 6.41 & 5.34 \\
\hline Measured' & 4.46 & 11.02 & 8.32 & 8.56 & 7.68 \\
\hline MCC-1 SI (g/m2) & 3.11 & 8.20 & 7.87 & 8.00 & 7.44 \\
\hline MCC-1 pH & 9.08 & 10.25 & 9.63 & 9.66 & 9.40 \\
\hline
\end{tabular}

\begin{tabular}{|lr|l|l|l|l|l|}
\hline PCT B (g/m2) & (Full CVS)\# & 0.42 & 0.07 & 0.19 & 0.27 & 0.13 \\
& (Na2O 2 16)\# & 0.53 & 0.04 & 0.17 & 0.21 & 0.13 \\
& Measured $^{*}$ & 0.35 & & 0.11 & 0.13 & 0.10 \\
\hline PCT Na (g/m2) & & & & & & \\
& (Full CVS)\# & 0.44 & 0.16 & 0.28 & 0.44 & 0.18 \\
& (Na2O 2 16)\# & 0.69 & 0.20 & 0.39 & 0.54 & 0.29 \\
& Measured & 0.32 & 1.23 & 0.38 & 0.52 & 0.26 \\
\hline PCT SI (g/m2) & Measured & 0.13 & 0.22 & 0.10 & 0.12 & 0.09 \\
\hline PCT pH & Measured & 10.55 & 12.03 & 11.39 & 11.48 & 11.05 \\
\hline
\end{tabular}

- Average value Irom duplicate tests.

by D. Kim $5 / 16 / 94$

Others composition
\begin{tabular}{|r|c|c|}
\hline Oxide & wasle (wi & glass (gi) \\
\hline Cr2O3 & 0.0015 & 0.0004 \\
$\mathrm{Cs} 2 \mathrm{O}$ & 0.0056 & 0.0015 \\
$\mathrm{Fe} 2 \mathrm{O} 3$ & 0.0001 & 0.00003 \\
$\mathrm{~K} 2 \mathrm{O}$ & 0.0554 & 0.0146 \\
$\mathrm{MgO}$ & 0.0001 & 0.00003 \\
$\mathrm{MnO}$ & 0.0001 & 0.00002 \\
$\mathrm{MoO3}$ & 0.0057 & 0.0015 \\
$\mathrm{SrO}$ & 0.0040 & 0.0011 \\
$\mathrm{P} 2 \mathrm{O} 5$ & 0.0072 & 0.0019 \\
$\mathrm{SO} 3$ & 0.0082 & 0.0021 \\
$\mathrm{Cl}$ & 0.0133 & 0.0035 \\
$\mathrm{~F}$ & 0.0112 & 0.0029 \\
$\mathrm{H}$ & 0.0050 & 0.0013 \\
\hline Total & 0.1174 & 0.0309 \\
\hline
\end{tabular}


WHC-SD-WM-VI-015 Revision 0

Hd uo!nnjos

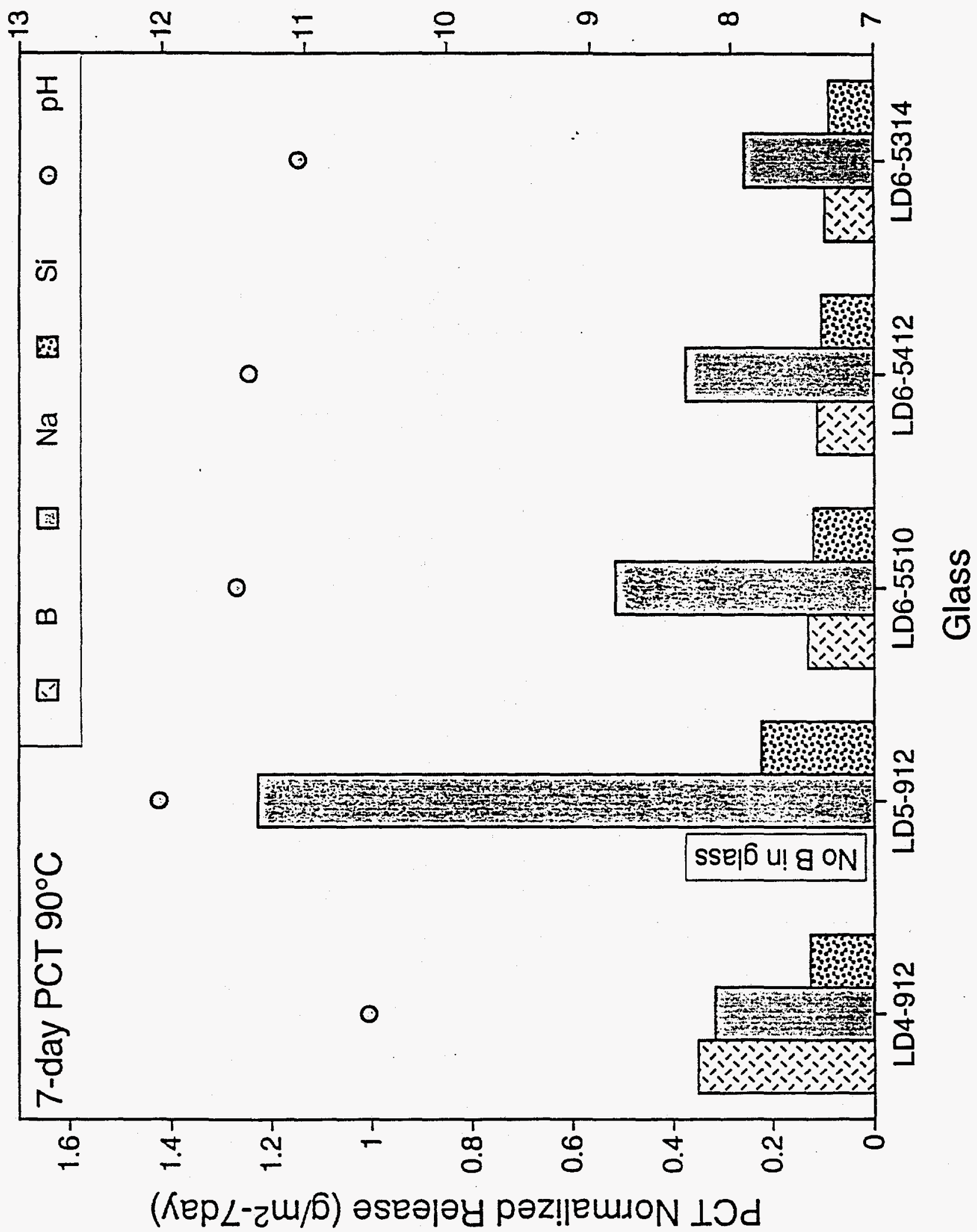

B-3 


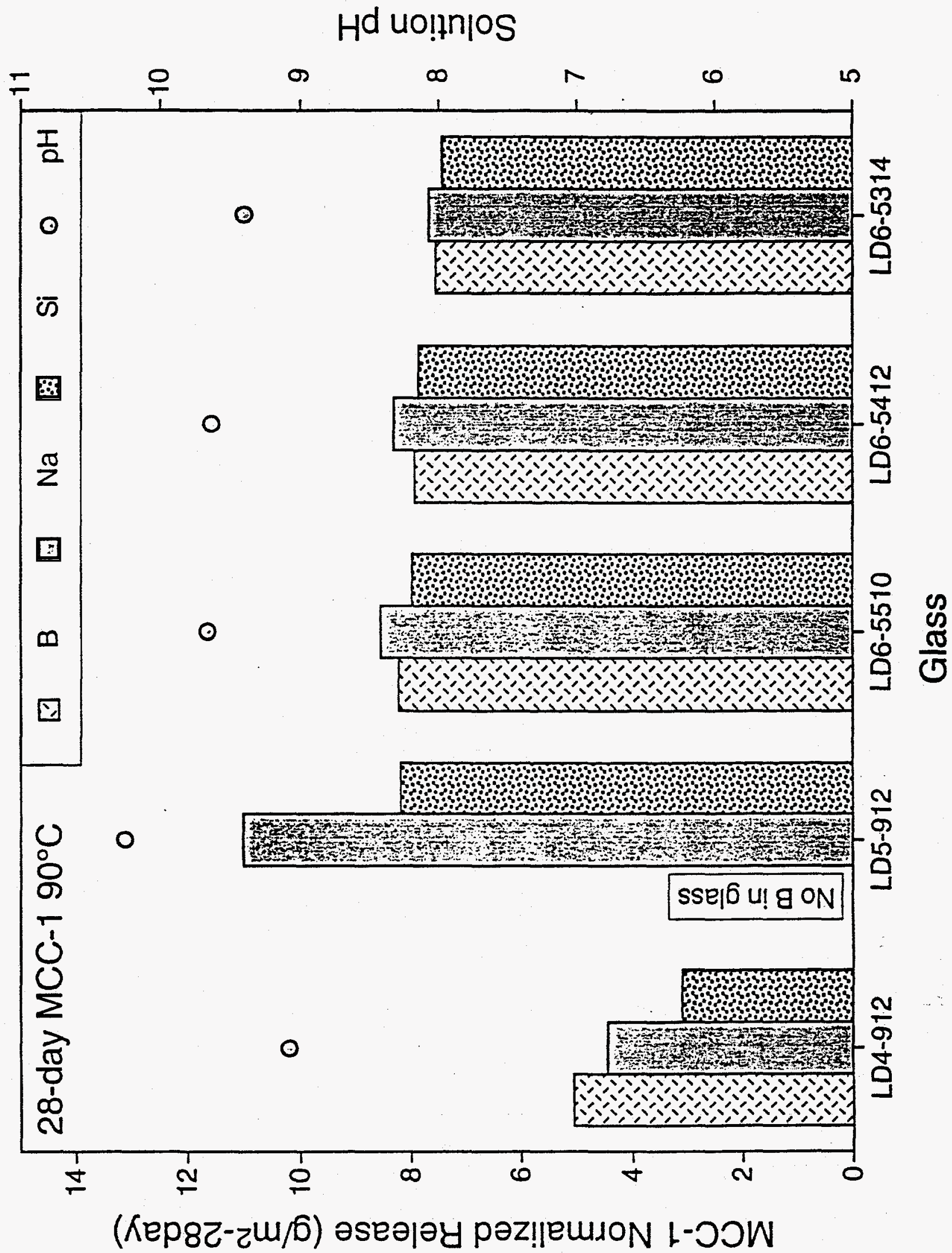


WHC-SD-WM-VI-015 Revision 0

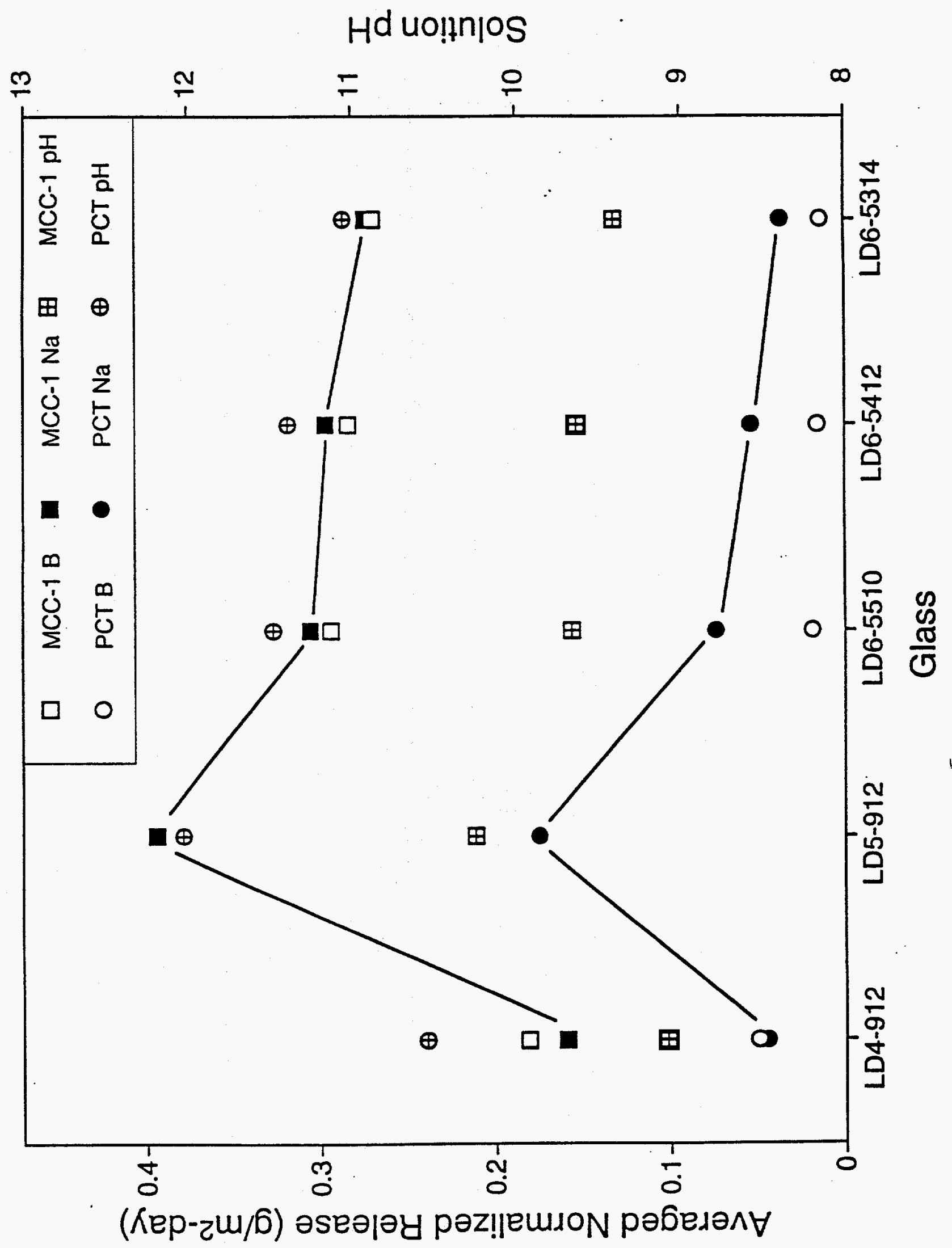




\section{Preliminary Evaluation of LLW Glasses}

Target Corrosion Rate $=1.00 \mathrm{E}-05(\mathrm{~cm} / \mathrm{yr})$

Glass Marbles (radius $=4 \mathrm{~cm}$ ) in Sulfur-Cement Marix

(by Mel Piepho, Rich Karnesky, and Paul Rittmann 1/94)

\begin{tabular}{|c|c|c|}
\hline $\begin{aligned}\text { (Glass density }) & = \\
(\text { Activation energy }) & = \\
R(\text { Gas Constant }) & =\end{aligned}$ & $\begin{array}{c}2.5 \\
-20000 \\
1.987 \\
\end{array}$ & $\begin{array}{l}(\mathrm{g} / \mathrm{cm} 3) \\
(\mathrm{cal} / \mathrm{mole}) \\
(\mathrm{cal} / \mathrm{mole}-\mathrm{K}\end{array}$ \\
\hline & $\ln (r)=$ & $A+Q / R T$ \\
\hline
\end{tabular}

If (long-term dissolution rate) $=$ (average release during 28-d MCC-1 or 7-d PCT)

\begin{tabular}{|c|c|c|c|c|c|}
\hline & & \multicolumn{4}{|c|}{ Glass Release Based on Normalized Na Releases } \\
\hline Glass & Type & $(\mathrm{g} / \mathrm{m} 2)$ & $\begin{array}{r}90^{\circ} \mathrm{C} \\
\left(\mathrm{g} / \mathrm{m}^{2}-\mathrm{d}\right)\end{array}$ & $(\mathrm{cm} / \mathrm{yr})$ & $\begin{array}{c}25^{\circ} \mathrm{C} \\
(\mathrm{cm} / \mathrm{yr})\end{array}$ \\
\hline \multirow[t]{2}{*}{ LD4-912 } & 28-d MCC-1 & 4.46 & 0.159 & $2.32 E-03$ & 5.49E-06 \\
\hline & 7-d PCT & 0.32 & 0.045 & $6.59 \mathrm{E}-04$ & $1.56 \mathrm{E}-06$ \\
\hline \multirow[t]{2}{*}{ LD5-912 } & $28-d$ MCC-1 & 11.02 & 0.394 & $5.75 \mathrm{E}-03$ & $1.36 E-05$ \\
\hline & 7-d PCT & 1.23 & 0.175 & 2.56E-03 & 6.05E-06 \\
\hline \multirow[t]{2}{*}{ LD6-5412 } & $28-d$ MCC-1 & 8.32 & 0.297 & $4.34 \mathrm{E}-03$ & $1.03 E-05$ \\
\hline & 7-d PCT & 0.38 & 0.054 & 7.84E-04 & 1.85E-06 \\
\hline \multirow{2}{*}{ LD6-5510 } & 28-d MCC-1 & 8.56 & 0.306 & $4.46 E-03$ & $1.05 E-05$ \\
\hline & 7-d PCT & 0.52 & 0.074 & $1.08 E-03$ & $2.55 \mathrm{E}-06$ \\
\hline \multirow[t]{2}{*}{ LD6-5314 } & 28-d MCC-1 & 7.68 & 0.274 & 4.01E-03 & $9.46 \mathrm{E}-06$ \\
\hline & 7-d PCT & 0.26 & 0.037 & 5.36E-04 & 1.27E-06 \\
\hline
\end{tabular}




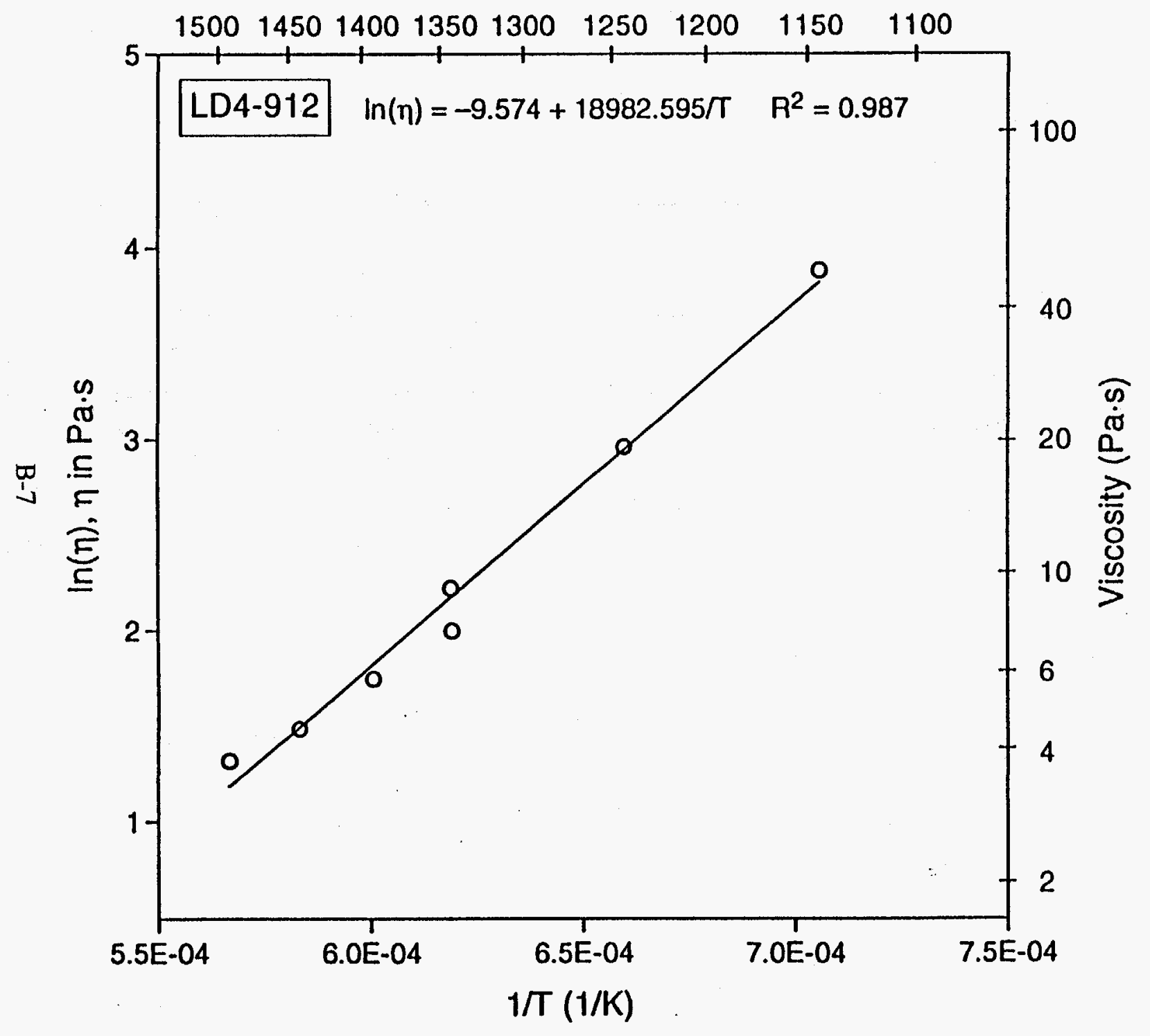

LD4-912

As Measured

\begin{tabular}{|c|c|}
\hline$T\left({ }^{\circ} \mathrm{C}\right)$ & Vis (Pas) \\
\hline 1342 & 7.39 \\
1392 & 5.76 \\
1442 & 4.44 \\
1492 & 3.74 \\
1343 & 9.21 \\
1243 & 19.35 \\
1144 & 48.50 \\
1045 & 153.41 \\
\hline
\end{tabular}

- Not used for Arrhenius fit

Calculated from Arrhenius fit

\begin{tabular}{|c|c|}
\hline$T\left({ }^{\circ} \mathrm{C}\right)$ & Vis (Pas) \\
\hline 1100 & 70.22 \\
1150 & 43.20 \\
1200 & 27.47 \\
1250 & 17.99 \\
1300 & 12.11 \\
1350 & 8.35 \\
1400 & 5.89 \\
1450 & 4.23 \\
1500 & 3.10 \\
\hline
\end{tabular}

$T\left({ }^{\circ} \mathrm{C}\right)$ at Armh Viscosity $=10 \mathrm{~Pa} \cdot \mathrm{s}$ 1325 


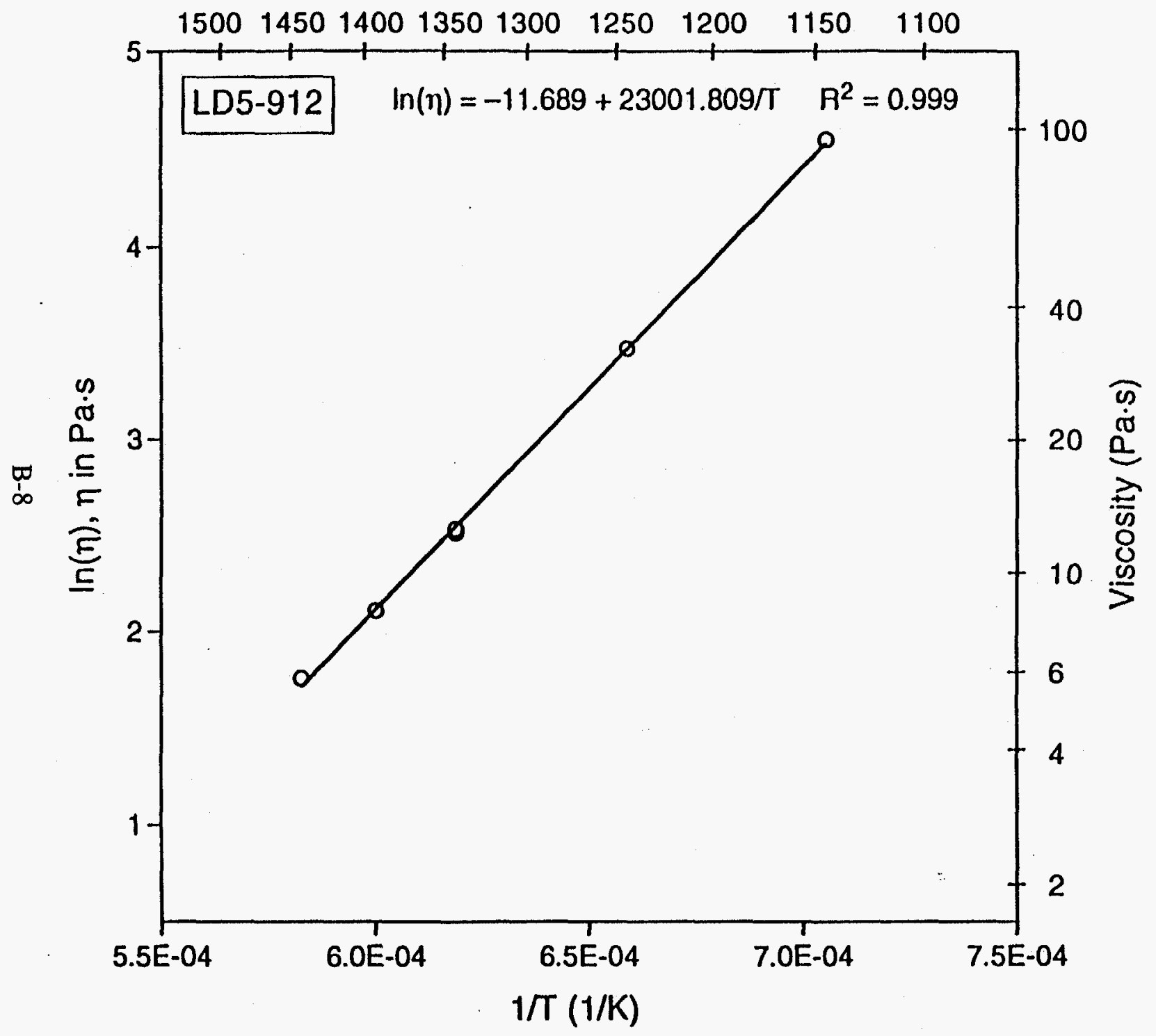

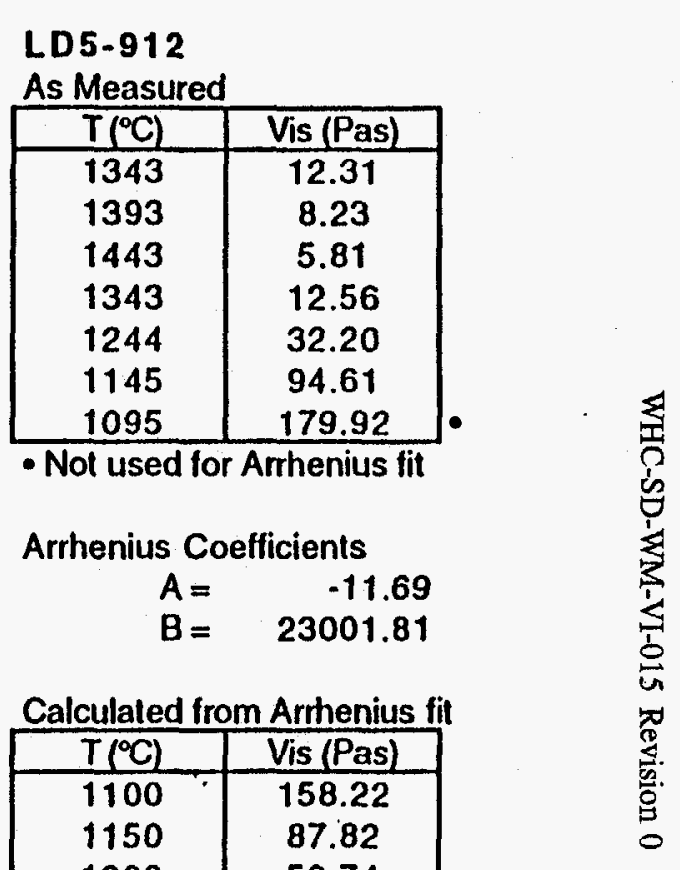




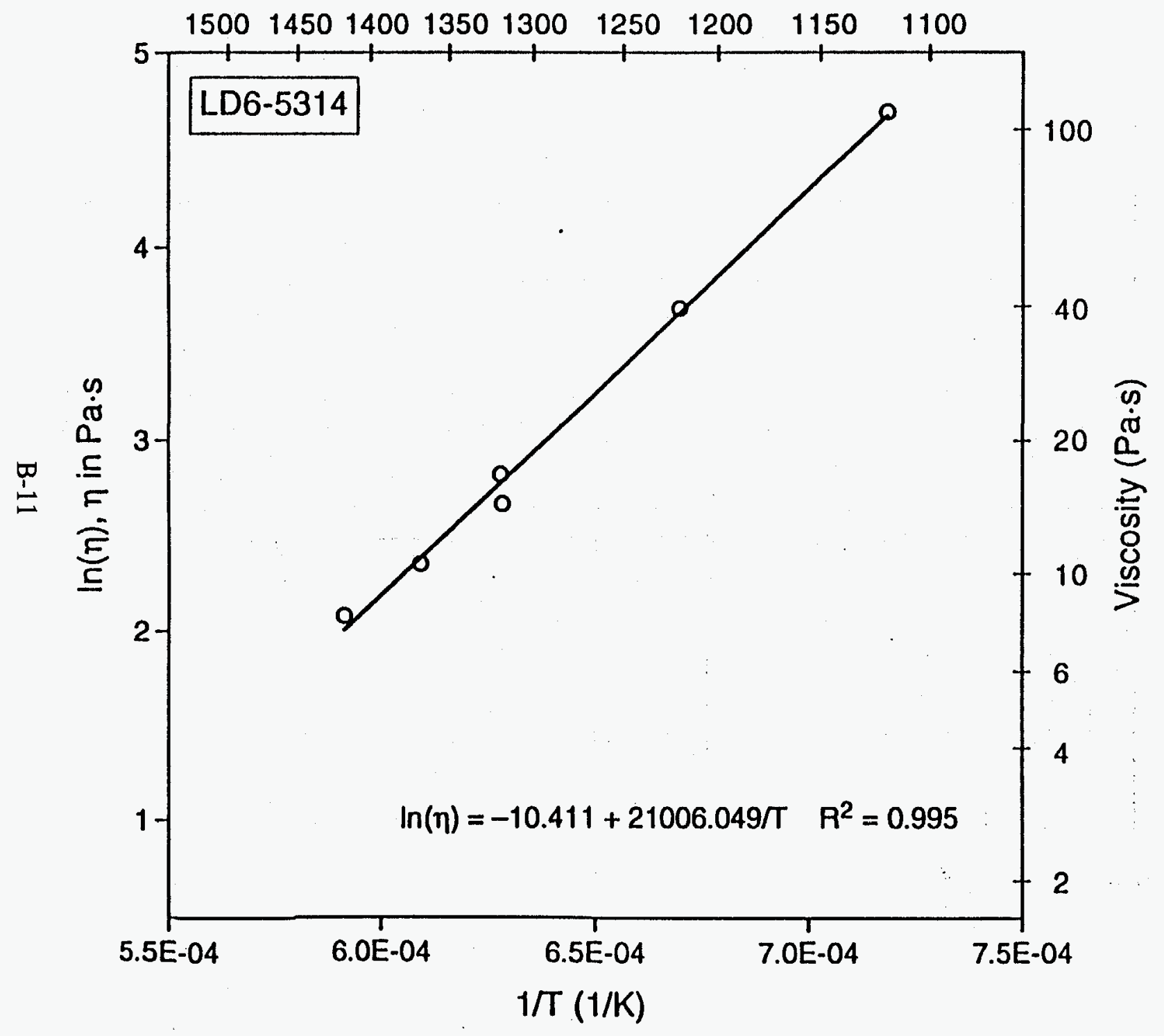

LD6-5314

As Measured

\begin{tabular}{|c|c|}
\hline$T\left({ }^{\circ} \mathrm{C}\right)$ & Vis (Pas) \\
\hline 1318 & 14.44 \\
1368 & 10.60 \\
1418 & 8.05 \\
1319 & 16.86 \\
1220 & 39.59 \\
1119 & 109.42 \\
1070 & 198.25 \\
\hline
\end{tabular}

Arrhenius Coefficients

$A=\quad-10.41$

$B=21006.05$

Calculated from Arrhenius fit

\begin{tabular}{|c|c|}
\hline$T\left({ }^{\circ} \mathrm{C}\right)$ & Vis (Pas) \\
\hline $1100 \cdot$ & 132.74 \\
1150 & 77.54 \\
1200 & 46.98 \\
1250 & 29.42 \\
1300 & 18.98 \\
1350 & 12.58 \\
1400 & 8.54 \\
1450 & 5.93 \\
1500 & 4.21 \\
\hline
\end{tabular}

$T\left({ }^{\circ} \mathrm{C}\right)$ at Arrh Viscosity $=10$ Pa.s 1379 